\title{
A Ouvidoria nos Três Níveis de Gestão da Saúde
}

Simone Ribeiro Spinetti

Tese apresentada ao programa de PósGraduação em Saúde Pública para obtenção do título de Doutor em Saúde Pública.

Área de Concentração: Serviços de Saúde Pública

Orientador: Prof. Dr. Paulo Antonio de Carvalho Fortes

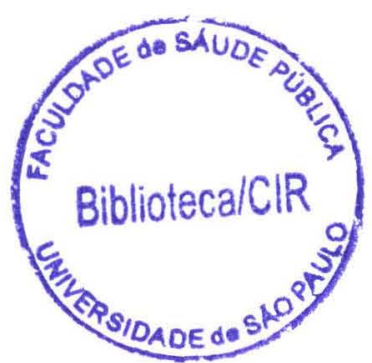

São Paulo

2007 
É expressamente proibida a comercialização deste documento, tanto na sua forma impressa como eletrônica. Sua reprodução total ou parcial é permitida exclusivamente para fins acadêmicos e científicos, desde que na reprodução figure a identificação do autor, título, instituição e ano da tese.

$$
4974212008 \text { doc }
$$


Dedico aos meus Pais Mário e Ney

Com muito amor! 


\section{Pacato-Cidadão Skank}

Pacato cidadão te chamei a atenção

Não foi à toa, não

Cl'est fini la utopia, mas a guerra todo dia

Dia a dia não

E tracei a vida inteira planos tão incríveis

Tramo à luz do sol

Apoiado em poesia e em tecnologia

Agora à luz do sol

$$
\begin{gathered}
\text { Pacato cidadão } \\
\text { Ô pacato da civilização }
\end{gathered}
$$

Pra que tanta TV, tanto tempo pra perder Qualquer coisa que se queira saber querer Tudo bem, dissipação de vez em quando é bão

Misturar o brasileiro com alemão

$$
\begin{gathered}
\text { Pacato cidadão } \\
\text { Ô pacato da civilização }
\end{gathered}
$$

Pra que tanta sujeira nas ruas e nos rios Qualquer coisa que se suje tem que limpar Se você não gosta dele, diga logo a verdade Sem perder a cabeça, perder a amizade

Consertar o rádio e o casamento é Corre a felicidade no asfalto cinzento Se abolir a escravidão do caboclo brasileiro Numa mão educação, na outra dinheiro

$$
\begin{aligned}
& \text { Pacato cidadão } \\
& \text { Ô pacato da civilização } \\
& \text { Pacato cidadão } \\
& \text { Ô pacato da civilização. }
\end{aligned}
$$


Agradecimento Especial:

À querida Gislaine Sacardo por toda a disponibilidade e preciosa ajuda. 


\section{Agradecimentos}

Ao meu orientador, Professor Dr. Paulo Antonio de Carvalho Fortes pelo apoio e dedicação e, por ter-me ajudado a construir uma vida profissional pautada em muita ética.

Agradeço aos Ouvidores: Geral do SUS, Estado SES/SP, M-1 e M-2 -- os quais optamos por não identificar -- mas que contribuíram de forma valiosa na construção de uma pequena teoria sobre a ouvidoria na saúde.

Agradeço a querida Munira Aiex por toda a ajuda, reflexões, trocas de angústias e por acreditar que a ouvidoria na saúde é possível.

Agradeço às Professoras: Claúdia Maria Bógus, Raquel Rapone Gaidzinski, Valéria Castilho e Vitória Kedy Cornetta, por toda a contribuição que deram à este trabalho.

Agradeço às minhas queridas amigas: Renilda, Cidinha e Ângela, por toda colaboração e disponibilidade, que fizeram a conclusão deste trabalho parecer mais suave.

Minhas queridas Amigas do CAPS-ad Jabaquara: Silvânia, Walkíria, Luigia, Rita, Lilly, Lilian, Rose, Ana Alice e Cléo, que além de terem de suportar minhas angústias, fizeram estes momentos parecerem simples e o resultado possível, além de contribuírem na reflexão da ouvidoria na rede pública.

Às minhas queridas amigas Dani Sacardo, Bettina Gerken Brasil e Sônia Maria Matsuda Lessa, que mesmo longe, sempre esteve presente nesta tese, pelo apoio e carinho de sempre.

Minhas queridas amigas Aquáticas Beth Chen, Ângela e Vandinha, pelos momentos de descontração, tão importante quando trilhamos este caminho.

Minha amiga Lilá de tantos anos, e que passou infindáveis domingos tendo que ouvir o que era ouvidoria. 
Elô minha querida irmã, que mesmo não tendo afinidade com o tema se esforça para conhecer, incentivando cada linha.

Agradeço a todos que de maneira direta ou indireta, ajudaram na construção desta reflexão. 


\section{RESUMO}

O termo Ombudsman surge na Suécia, no século XVI, tendo como função exercer o controle da administração pública, cabendo denunciar falhas na administração contribuindo para difundir os principios de justiça entre os cidadãos. $O$ papel do Ombudsman foi difundido em vários países da Europa. Na América Latina, o principal país a se apropriar desta função foi Trinidad Tobago em 1976. No Brasil têm se relato do papel do ouvidor-mor, desde 1548, que tinha como função representar os donatários. Houve um intervalo de tempo, desde a instituição do ouvidor-mor no Brasil Colônia, e a retomada do interesse pelo tema a partir da década de 1960, mesmo assim, sem muita repercussão. Na década de 1980, Professor Afonso Arinos propõe a implantação da ouvidoria, denominada "Defensoria do Povo". Na década de 1990, com a instituição do Código de Defesa do Consumidor, diversas empresas privadas e públicas foram se apropriando desta função. $\mathrm{Na}$ área da saúde a ouvidoria teve seu início com a introdução da Lei $8080 / 90$, que dispõe sobre as condições para a promoção, proteção e recuperação da saúde, sua organização e o funcionamento dos serviços correspondentes. Em 2004, o Ministério da Saúde instituiu a Portaria no. 1.193, que disciplina o funcionamento do Departamento de Ouvidoria-Geral do Sistema Unico de Saúde. No Estado de São Paulo, a atenção ao tema surgiu em 1999 com a elaboração da Lei 10.294/99, cria-se um sistema de Ouvidoria na Administração Pública Estadual, desencadeando o processo de instituição de ouvidorias em equipamentos de saúde de responsabilidade da esfera estadual. Em 2001, foi instituída a Ouvidoria Geral do Município de São Paulo, cuja proposta é sistematizar informações recebidas do munícipe e dos vários canais ligados à administração municipal. Entendemos, que as ouvidorias como estruturadas no Brasil, são peculiares em forma e localização, das demais propostas em outros países do mundo. Focando a ouvidoria na saúde, na sua grande maioria, a mesma está ligada ao executivo, e sua ação é muito mais próxima do usuário/cidadão, do que as ouvidorias tradicionais. Esta proximidade é saudável para a atuação do ouvidor, mas gera também muitos conflitos que deverão ser mediados pelo ouvidor. Estudamos as ouvidorias na saúde, nos três niveis de gestão: federal, estadual e municipal. Encontramos uma diversidade de ações na área da ouvidoria. Percebe-se uma falta de conceituação do papel da ouvidoria, não entendimento e apoio a este novo ator social na saúde, por parte do gestor, desvirtuamento da ação do ouvidor. Frente às questões levantadas, entendemos que a ouvidoria não se justifica se não houver o interesse e apoio do gestor central, bem como, consideramos, que deverá haver maiores discussões sobre o tema, fazendo com que, se estruture de forma mais organizada a ação da ouvidoria, elaboração de um conceito básico de ouvidoria, objetivos e papel da ouvidoria na saúde. Frente às questões levantadas, elaboramos uma proposta de estrutura de ouvidoria na saúde.

Palavras-chaves: Ouvidoria na saúde, administração pública na saúde 


\section{SUMMARY}

The term Ombudsman appears in Sweden, in century XVI, having as function to exercise the control of the public administration, and fitting to denounce imperfections in the administration contributing to spread out the principles of justice between the citizens. The paper of the Ombudsman was spread out in some countries of the Europe. In Latin America, the main country if to appropriate of this function was Trinidad Tobago in 1976. In Brazil they have if story of the paper of the ouvidor-mor, since 1548, that it had as function to represent the donees. It had a time interval, since the institution of the listener-mor in Brazil Colony, and the retaken one of the interest for the subject from the decade of 1960, exactly thus, without much repercussion. In the decade of 1980, it considers the implantation of the ouvidoria, called "Defendant of the People". In the decade of 1990 with the institution of the Code of Defense of the Consumer, diverse public and private companies had been appropriating of this function. In the health's field the ouvidoria had its beginning with the introduction of Law 8080/90, that it makes use on the conditions for the promotion, protection and recovery of the health. Other initiatives had been developed recently in June of 2004, the Health Department, from Health Ministry instituted Portaria in. 1.193, that it disciplines the functioning of the Department of General Ouvidoria of the SUS. In the State of São Paulo, the attention to the subject appeared in 1999 with the elaboration of Law 10,294/99, instituting a system of Ouvidoria in the State Public Administration, unchaining the process of institution of ouvidorias in equipment of health of responsibility of the State sphere. In the City of São Paulo, in 2001, the General Ouvidoria of the City of São Paulo was instituted, whose proposal is systemize information received from the townsperson and the some on canals to the municipal administration. We understand, that the ouvidorias as structuralized in Brazil, are peculiar in form and localization, from proposed in other countries of the world. Focussing health's ouvidoria in its great majority, it is linked to the executive, and its position, the Ouvidor is much closer to the user/citizen than traditional ouvidorias. This proximity is healthful for the performance of the Ouvidor, but it also generates many conflicts that will have to be mediated by the same. We study the ouvidorias in the health, the three levels administration: Federal, State and Municipal. We find a diversity of action in the area of the ouvidoria. A lack of conceptualization of the paper of the ouvidoria is perceived, no agreement and support to this new social actor in the health, on the part of the manager, distorting the action of the ouvidor. Related to the raised questions, we understand that the ouvidoria does not justify if it will not have the interest and support of the central manager, as well as, we consider, that must have greaters quarrels on the subject, making with that, if structuralizes more of form organized action of the ouvidoria, elaboration of a basic concept, objectives and paper of the ouvidoria in the health's area. Related from raised questions; we elaborate a proposal of structure of ouvidoria in the health.

Keywords: health's ombudsman, public administration in health 


\section{Índice}

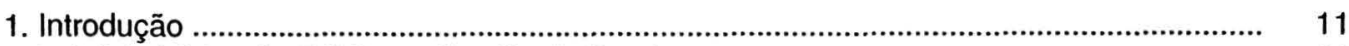

1.1. A Administração Pública e Gestão de Serviços ............................................................. 11

1.2. Participação do Usuário na Administração Pública ...........................................................

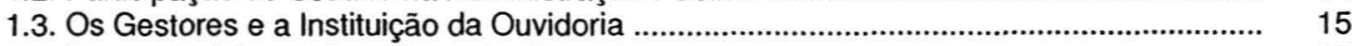

1.4. Breve Histórico da Instituição do Ombudsman ................................................................ 17

1.5. O Ombudsman na América Latina ............................................................................... 20

1.6. A Experiência Brasileira ........................................................................................... 21

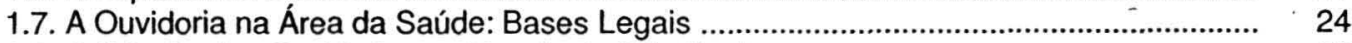

1.8. A Criação das Ouvidorias no Estado de São Paulo ...................................................... 26

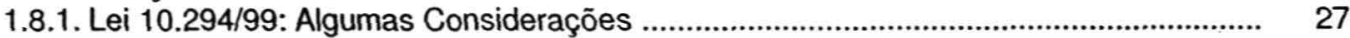

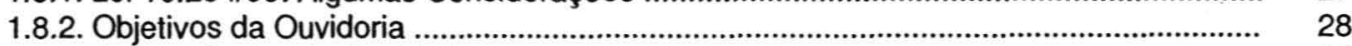

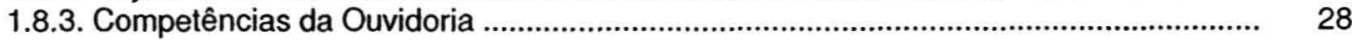

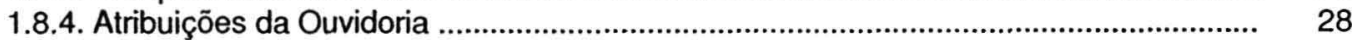

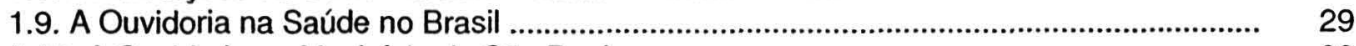

1.10. A Ouvidoria no Município de São Paulo ........................................................................... 29

1.11. As Três Esferas de Governo: Federal, Estadual e Municipal ....................................... 30

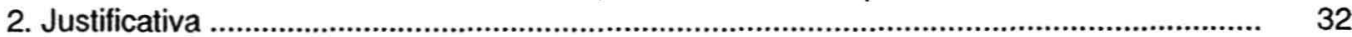

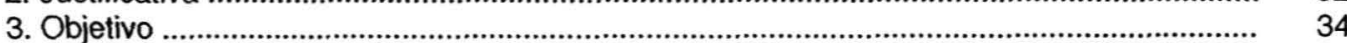

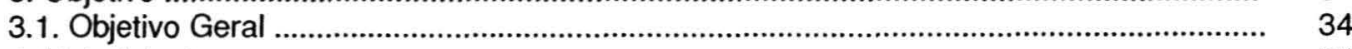

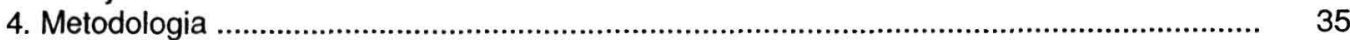

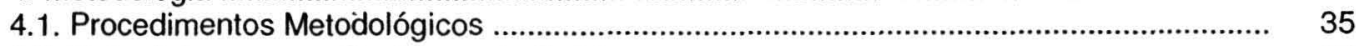

4.2. Entrevistas com os Ouvidores da Saúde ................................................................... 35

4.2.1. Entrevista com o Ouvidor Geral do Ministério da Saúde - "Ouvidor Geral do SUS .... 37

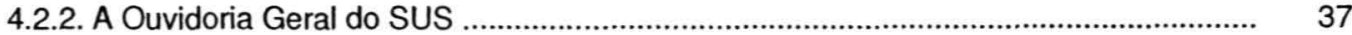

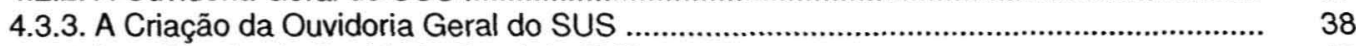

4.2.4. Localização da Ouvidoria Geral do SUS ................................................................ 40

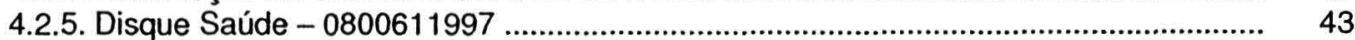

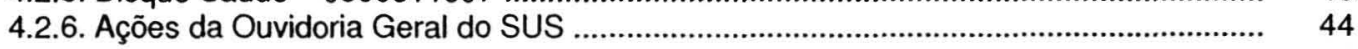

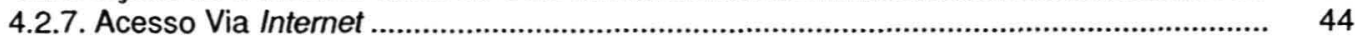

4.3. Entrevista com o Ouvidor da Secretaria do Estado da Saúde de São Paulo - "Ouvidor 50 do Estado SES/SP"

4.3.1. A Ouvidoria do Estado da Saúde de São Paulo - SES/SP - "Ouvidoria SES/SP" ..... 51

4.4. Entrevista com o Ouvidor da Secretaria Municipal da Saúde - SMS - "Ouvidor M-1" ... 54

4.4.1. A Ouvidoria da Secretaria Municipal da Saúde - "Ouvidoria M-1" .............................. 54

4.5. Entrevista com Ouvidor da Saúde - Secretaria Municipal da Saúde - "Ouvidoria M-2" 55

4.5.1. A Ouvidoria da Secretaria Municipal da Saúde - "Ouvidoria M-2" .............................. 55

4.6. Análise dos Dados ................................................................................................... 56

5. Aspectos Éticos da Pesquisa ...................................................................................... 58

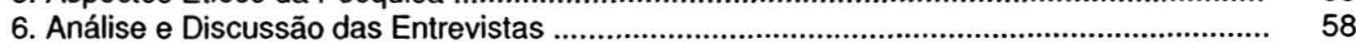

6.1. Ouvidoria na Administração Pública de Saúde nos Três Níveis de Gestão ..................... 59

6.2. A Importância do Comprometimento dos Gestores com a Instituição da Ouvidoria ....... $\quad 61$

6.3. Participação do Usuário na Administração Pública de Saúde ........................................... 65

6.4. Papel da Ouvidoria no Setor Público de Saúde ............................................................... 68

6.4.1. A Ouvidoria e a Gestão dos Serviços....................................................................... 70

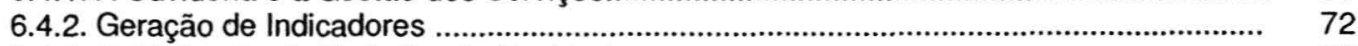

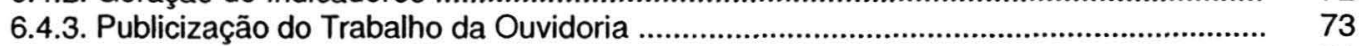

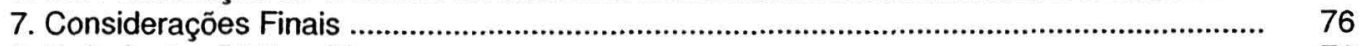

8. Referências Bibliográficas ........................................................................................... 78

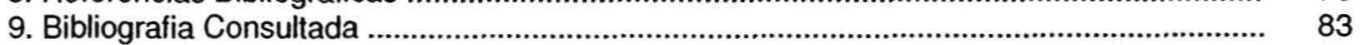

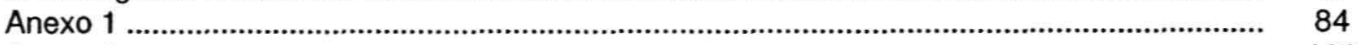

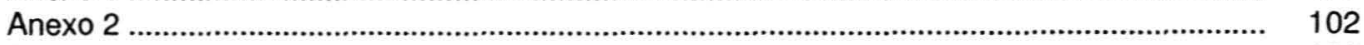

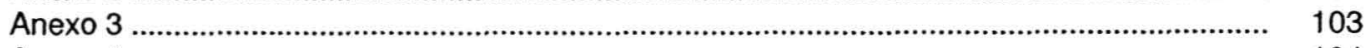

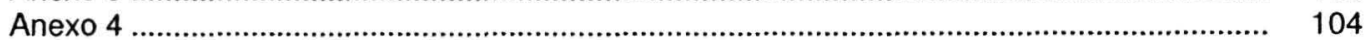




\section{INTRODUÇÃO}

\subsection{A Administração Pública e Gestão de Serviços}

Inicia-se o presente estudo reportando o papel da Administração Pública.

Segundo Stutinitz (1998) citado por STUTINITZ (1999) a redemocratização do país é um fato. Existiam demandas sociais represadas por mais de duas décadas de regime autoritário. A estas demandas adicionaram-se conceitos relativamente novos como o exercício da cidadania, direitos do consumidor, controle e participação social. Estas "novidades", ou seja, a possibilidade de instituição de canais de comunicação fizeram com que a sociedade brasileira viesse a enxergar o Estado sob uma ótica, completamente nova, ou seja, a ótica do cliente. E de um cliente, espera-se, cada vez mais exigente quanto à qualidade dos serviços prestados pela Administração pública.

Desse modo Di PIETRO (2003) entende que em sentido objetivo a Administração Pública abrange as atividades exercidas pelas pessoas jurídicas, órgãos e agentes incumbidos de atender concretamente às necessidades coletivas, corresponde à função administrativa, atribuída preferencialmente, aos órgãos do Poder Executivo. O serviço público é toda atividade que a Administração Pública executa, direta ou indiretamente, para satisfazer a necessidade coletiva sob regime jurídico predominantemente público, abrange atividade que por sua essencialidade ou relevância para coletividade, foram assumidas pelo Estado, com ou sem exclusividade. (p.598)

Contudo, elucida Di PIETRO (2003), a Administração Pública está sujeita a controle por parte dos Poderes Legislativo e Judiciário, além de exercer, ela mesma, o controle sobre os próprios atos, mas não abrange também o controle dos demais poderes. A finalidade do controle é a de assegurar que a Administração atue em consonância com os princípios que Ihe são impostos pelo ordenamento jurídico, como os da legalidade, moralidade, finalidade pública, publicidade, motivação, impessoalidade, em 
determinadas circunstâncias, abrange também o controle chamado de mérito e que diz respeito aos aspectos discricionários da atuação administrativa.

O controle da Administração Pública poderá ser exercido de várias formas: através do administrado, o real controle que é o controle popular, através do Ministério Público que possui uma independência e uma gama de possibilidades, para checar denúncias e provocar ações, e também através do direito de petição, quando o cidadão, mesmo que não pague taxas, poderá interpor este recurso contra a Administração Pública, que não poderá se eximir de uma resposta. Bem como a Administração Pública possui o controle dos próprios atos, através do autotutela e tutela, que é exercido por órgãos externos à Administração Pública e, na esfera federal, supervisão ministerial. (Di PIETRO, 2003).

O controle que interessa ao tema estudado é o controle do administrado, ou seja, do cidadão, conforme Di Pietro (2003):

... o administrado participa dele, do controle, à medida que pode $e$ deve provocar o procedimento de controle, não apenas na defesa de seus interesses individuais, mas também na proteção do interesse coletivo. A Constituição outorga ao particular determinados instrumento de ação a serem utilizados com essa finalidade. É esse provavelmente, o mais eficaz meio de controle da Administração Pública: o controle popular. (p.598).

Entretanto para OLIVEIRA (2003) o cidadão é mal informado quanto aos seus direitos, não sabendo nem mesmo a quem ou a onde se dirigir e, ainda, como a comunicação é falha no setor público, seus administradores passam a serem rotulados de inoperantes. A Ouvidoria cabe implantar ações e mecanismos, permitindo ao cidadão o entendimento e o incentivo para o exercício de sua cidadania e ao administrador público, a possibilidade de análise e alteração de procedimentos.

Desse modo OLIVEIRA (2003) sugere que obrigatoriamente toda e qualquer entidade da administração pública, deve possuir um sistema de acolhimento de reclamações e reivindicações e denúncias pelas seguintes razões:

- Os cidadãos têm o direito de expressar comentários, críticas e de serem ouvidos; 
- A tabulação dos resultados de um sistema de reclamação dirige atenção e providências para áreas que necessitam de melhorias e aperfeiçoamento;

- Um sistema de reclamação sensível, competente e eficaz oferece um sentimento de satisfação ao cidadão reclamante, que sente respeito à sua dignidade e cidadania;

- Um bom sistema de reclamação propicia economia de dinheiro e tempo ao administrador público, e, conseqüentemente, a toda a sociedade contribuinte. (p.25)

\subsection{Participação do Usuário na Administração Pública de Saúde}

Todavia sem a participação do usuário, neste processo, não será possível efetivar o papel da ouvidoria.

A ouvidoria brasileira é sem dúvida um canal de diálogo com a população, uma porta aberta para a participação popular através do escutar da reivindicação e da reclamação, um celeiro de recomendações para a melhoria do serviço público, um espaço na esfera do respeito ao ser humano. (OLIVEIRA, 2005).

Neste sentido, BOBBIO (1992) contribui que sem os direitos do homem reconhecidos e protegidos não haverá democracia, sem democracia não existem as condições mínimas para a solução pacífica dos conflitos. Em outras palavras, afirma o autor, a democracia é a sociedade dos cidadãos. Portanto, para que a democracia se estabeleça é necessário que os cidadãos tenham oportunidade de participar deste processo.

Para OLIVEIRA (2001), é muito importante do que a administração publica busque a qualidade de seus serviços, através de seu cliente, o cidadão. Até porque os serviços ofertados afetam diretamente a qualidade de vida das pessoas e contam com o recolhimento de impostos.

O canal da ouvidoria promove a abertura de um espaço pedagógico, de informação e voz, podendo ser entendida como um espaço amplamente pedagógico.

Para PÒ, ABRÚCIO (2006) na década de 1960 o Estado brasileiro passou pelo regime militar, que levou, em termos de administração pública, a 
um maior insulamento da burocracia em relação a qualquer tipo de accountability, ou seja, qualquer tipo de regulação do cidadão com relação ao estado, ao mesmo tempo em que ocorreu uma grande expansão da intervenção estatal. Nesse contexto, desenvolveu-se uma visão tecnocrática de atuação estatal, bem como, criaram-se, fortes relações, entre a burocracia com setores privados, sem que houvesse transparência nesse arranjo.

Desse modo contribuem os Autores que as principais ações previstas no plano da accountability era a participação de usuários, a utilização de contratos de gestão como forma de responsabilização por resultados, adoção de mecanismos de controle social nos serviços locais e o aumento da transparência na implementação das ações do governo, possibilitando seu acompanhamento e avaliação. As noções de controle e accountability ficariam, dessa forma, estreitamente ligadas à avaliação e publicidade dos resultados e informações dos órgãos, assim como na institucionalização de mecanismos de participação. (GRIFOS NOSSOS)

Cunill Grau (1987) citado por BELLISOMI (2003), afirma que o maior controle da sociedade sobre os governantes e burocratas, necessita de dois elementos fundamentais para a sua realização. Em primeiro lugar, a articulação com as instituições da democracia representativa, de forma, que os mecanismos participativos sejam entendidos como ampliação desta. A outra necessidade é a criação de mecanismos de accountability, ou responsabilização da administração pública.

Entende-se que, o conceito de accountability, trata-se, conforme conceituam vários autores, como um processo de responsividade dos Governantes frente às suas ações. Para tanto, é preciso que haja um controle destas ações, cabendo, neste contexto a instituição de ouvidorias públicas.

Para CRUZ (1999) iniciativas de partidos políticos e de grupos organizados da sociedade civil têm procurado criar as condições necessárias para que o cidadão exerça um controle mais eficaz sobre a coisa pública. Com relação à Administração Pública, proposições têm sido feitas no sentido de tornar mais eficaz a participação da sociedade na definição de prioridades e no controle das políticas públicas. O controle social passa, sem dúvida, pelo surgimento de uma atitude de accountability, na sociedade brasileira. (p.23) 
Nossa democracia é democracia representativa. Nossos estados são muito extensos, para que todos se reúnam, e muito populosos para que se possa imaginar um diálogo que incorpore cada um de seus cidadãos. As questões políticas são complexas demais para que dispensemos a especialização dos governantes e, por sua vez, os afazeres privados absorvem demais cada um de nós, reduzindo ao mínimo o tempo para a participação política. A incorporação de tantos grupos ao demos trabalhadores, mulheres, imigrantes - ampliou a profundidade das clivagens em seu seio, tornando indispensável à existência de alguma forma de mediação. (MIGUEL, 2005)

DÂMASO (1996) esclarece que a cidadania, enquanto categoria éticojurídica-política - escapou do domínio do pensamento liberalista, na medida em que veio acompanhando a transformação estrutural do Estado. A passagem do "Estado restrito" ao "Estado ampliado" coloca-nos diante de um Estado plural, que deve articular a diversificação das vontades políticas, reconhecendo nos interesses diversos - e adversos - a sua validação éticomoral e a sua legitimidade sóciopolítica.

\subsection{Os Gestores e a Instituição da Ouvidoria}

Entende-se que frente ao acima exposto, a sensibilização e comprometimento dos gestores públicos com relação ao estabelecimento da ouvidoria em instituições públicas de saúde é de grande importância, pois muito provavelmente, com este apoio a ouvidoria poderá abrir-se enquanto um canal efetivo de participação do cidadão, bem como, poder vir a ser um respeitável instrumento de gestão.

Neste sentido PINTO (2001) entende o ouvidor por não possuir poderes coercitivos, mas o de sugerir e recomendar necessita do respaldo encontrado na Lei ou na alta autoridade administrativa, sejam públicas ou privadas. Sem esse respaldo, o poder de resposta do ouvidor fica prejudicado, não se diferenciando dos servicos de encaminhamento de reclamações. (GRIFOS NOSSOS)

Desse modo PEREIRA (2000) afirma que a implantação de ouvidorias é uma estratégia gerencial. A escolha de determinadas estratégias, neste 
caso os serviços de ouvidoria, e a forma como serão concebidos, contribui para transformar, ou manter e ampliar, a direção e a dominação de forças em correlação na sociedade e na instituição.

Sendo assim CENTURIÃO (2003) esclarece que no âmbito do serviço público, existe o risco da ação da ouvidoria ficar atrelada a interesses políticos, nem sempre sintonizados com o interesse público. O Autor afirma que se os serviços públicos ao implementarem ouvidorias, deve ser dentro do espírito de comprometimento com o cidadão, munidas de autonomia e das salvaguardas necessárias, ou senão terão a existência meramente decorativa, com atuação burocrática e nenhum benefício trazido aos usuários, além de se tornarem reféns de pressões e interesses de grupos internos e externos. (GRIFOS NOSSOS)

Ao se instituir uma ouvidoria abre-se um espaço de participação social, portanto, o gestor poderá tomar contato com questões diversas, que em alguns momentos poderão confrontar sua administração. Por outro lado, estas demandas poderão ser utilizadas para promover mudanças.

Neste contexto, OLIVEIRA (2003) compreende que as ouvidorias estão atuando como agentes indutores do processo de participação popular, reforçando a sua função de orientar e elevando a qualidade dos serviços prestados pela máquina administrativa. Este estreitamento de relações promove o amadurecimento e o equilíbrio na busca de soluções aos problemas apresentados, tanto pelo cidadão que exige seus direitos, com mais critérios, como pelo administrador público na avaliação de prestador de serviço.

Desse modo HIRSCHMAN (1970) esclarece que apesar de ser uma teoria de meados dos anos 60, cabe muito bem para contextualizar a presente discussão. Este Autor trabalhou com o tema: Saída, Voz e Lealdade, cujo foco foi a relação entre proprietários de uma ferrovia frente a demanda dos usuários com relação ao serviço prestado.

Para HIRSCHMAN (1970), existiam duas possibilidades, ou seja, a primeira a ferrovia dá "voz" aos seus clientes, e a segunda eles "saem" trocando o serviço por outras possíveis alternativas. Com relação à lealdade, esclarece o autor, ela é o reforço da voz, através do adiamento da saída. Em 
um serviço privado, esta situação é mais facilmente gerenciável pelo cidadão, no caso de serviços públicos a voz fica mais comprometida, conforme abaixo:

“... os funcionários públicos são insensíveis à saída, porque contam com uma série de recursos financeiros independentes dos ganhos provenientes de vendas. (P.53)

Contudo HIRSCHMAN (1970) entende que quando a opção de saída não está ao alcance, a opção da voz é a única maneira, que clientes insatisfeitos têm para reagir.

PEREIRA (2000) colabora com o tema ao discutir a Teoria de HIRSCHMAN (1970), com relação as ouvidorias hospitalares:

"As ouvidorias ... públicas poderão distinguir-se, umas das outras pela atuação no sentido de ampliar ou minimizar a voz do usuário, uma vez que, para estes não há opção de saída, a ouvidoria pode, dentro dos limites que as relações institucionais Ihe impõem, funcionar de forma a ampliar a voz do usuário e, nesse caso terá um caráter mais democratizante, pode também minimizar sua voz, apenas contemporizando suas reclamações tendo, nesse caso um caráter mais liberal e autoritário. Os limites institucionais dizem respeito às relações internas, entre as quais destacou-se o respaldo institucional à ouvidoria, à opção institucional, explícita ou implícita, a uma das propostas para a área da saúde, e à implantação dos princípios SUS." (PEREIRA, 2000 p.39) (Grifos Nossos)

Para FLEURY (2003), a cidadania pressupõe a inclusão ativa dos indivíduos em uma comunidade política nacional que comparte um sistema de crenças em relação aos poderes públicos, à própria sociedade e ao conjunto de direitos e deveres que estão envolvidos na natureza da cidadania.

Todavia a instituição de uma ouvidorias poderá ser permeada de conflitos de interesses. Considera-se interessante que haja apoio do gestor público, no sentido de ampliar a voz do usuário, propondo-se assim a melhoria da administração pública.

\subsection{Breve Histórico da Instituição do Ombudsman}

$\mathrm{O}$ termo ombudsman surge na Suécia, no século $\mathrm{XVI}$, o primeiro ombudsman, com o aparecimento do grande senescal (drotsen), que era funcionário do rei encarregado de exercer o controle da atividade dos juizes do Reino Sueco. 
Com a deposição do rei, houve uma Assembléia Nacional Constituinte, que veio a promulgar a Constituição, a Regeringsform de 1809, que introduziu a figura do Justitieombudsman, ou delegado parlamentar, a fim de exercer o controle da administração nos termos do art. 96: "Controlar a observação das leis pelos tribunais e funcionários e processar junto aos tribunais competentes, conforme as leis, aqueles que no exercício de suas funções tenham, por parcialidade, favor ou qualquer outro motivo, cometido ilegalidades ou negligenciado o cumprimento adequado de seus deveres de ofício." (AMARAL Jr. 1993)

Ainda conforme relata AMARAL Jr. (1993) o Justitieombudsman permaneceu com as atribuições de controle sobre as autoridades judiciárias e administrativas, sendo, sem dúvida, a necessidade de controle sobre um governo permanente que levou os parlamentares à criação desta figura original, sem paralelo na história jurídica européia.

Na Suécia, em 19 de maio de 1915, instituiu-se o ombudsman militar (Militieombudsman - MO) com funções de controlar a administração militar. E, em 1967, criou-se mais um cargo, o do terceiro ombudsman, para cuidar de matérias da esfera cível. A função, embora repartida entre três ombudsman com diferentes esferas de atribuições, foi unificada no mesmo nível de importância e sob uma mesma denominação, a de Justitieombudsman ou ombudsman. (LARA PINTO 1993)

O ombudsman não possui poder de revogar ou anular decisões, atuando mais no processo de persuasão e influência, podendo recomendar ou propor mudanças nas ações governamentais, podendo investigar questões as quais toma conhecimento por diversos meios, como a imprensa. Esta, por sua vez, exerce um importante papel, informando a sociedade dos resultados das investigações e apurações. O ombudsman, ao denunciar falhas na administração, contribui para difundir principio de justiça entre os cidadãos. (LARA PINTO 1993)

Conforme relata PINSKI (2003), a palavra "man" para os suecos, significa "ser humano" e ombuds, significa "representante", "procurador", por isso, não comporta variações como: ombudswoman, ombudsperson ou ombudsmen, apesar do uso indiscriminado em todo o mundo. 
Mas, a partir da criação da função de ombudsman sueco em 1809, progressivamente, outros países instituíram esta figura, por vezes seguindo fielmente o modelo sueco, ou pequenas adaptações ou alterações. Em alguns casos o nome originário foi mantido; em outros, modificado, traduzindo-se apenas o significado da palavra. (LARA PINTO 1993)

LARA PINTO (1993) e AMARAL Jr. (1993) contribuem fazendo um extenso levantamento da adoção do papel do ombudsman em outros países, que resumimos a seguir:

Verifica-se abaixo alguns países que adotaram a figura do Ombudsman:

Finlândia - Oikeusasiamies - 1919 - nomeado pelo Parlamento, mandato de 4 anos, coincidindo com o mandato parlamentar; acesso direto pelo cidadão civil e militar.

Noruega - Ombudsman (MO) - 1952 - nomeado pelo Parlamento mandato de 4 anos, acesso direito pelo cidadão e área militar; prazo para apresentação da queixa é de 1 ano.

Dinamarca - Ombudsman - 1953 - nomeado pelo Parlamento mandato de 4 anos; acesso direto pelo cidadão e militar; prazo de carência de 1 ano para apresentação da queixa.

Nova Zelândia - Parliamentary Comissioner - 1962 - nomeado pelo Governador Geral, sob recomendação da Câmara dos Representantes; mandato de 3 anos; acesso direto pelo cidadão; aceita reclamações de sociedades, associações públicas ou privadas.

Inglaterra - Parliamentary Comissioner - 1967 - nomeado pelo Parlamento; cargo vitalício; acesso indireto, através de um parlamentar, podendo ter acesso individual ou coletivo.

Israel - Comissionário para Queixas Públicas (traduzido) - 1971 nomeado pelo Presidente do Estado por recomendação da Comissão do Parlamento, mandato de 5 anos, podendo ser reeleito; acesso direto pelo cidadão, ou por estrangeiros.

França - Médiateur - 1973 - nomeado pelo Conselho de Ministros, mandato por prazo indeterminado; acesso direito pelo cidadão, não há prazo de carência para o acesso, ou seja, podendo a reclamação ocorrer, mesmo que já tenha decorrido algum tempo do fato acontecido. 
Portugal - Provedor da Justiça - 1975 - nomeado pelo Presidente da República; mandato por prazo indeterminado; acesso direto pelo cidadão, não existe prazo de carência para o acesso.

Espanha - Defensor del Pueblo - 1978 - nomeado pelo Parlamento; mandato de 5 anos; acesso direto pelo cidadão; o acesso somente pode ser feito de forma individual.

Com relação ao acima exposto, grande parte das ouvidoria instituídas estão ligadas ao Poder Legislativo, porém existem experiências relacionadas ao Poder Executivo.

Na Europa, a importante iniciativa, foi consignada em 1992, pelo Tratado de Maastricht, ao criar um ombudsman europeu, no âmbito da União Européia, cabendo-Ihe apresentação de relatórios anuais ao Parlamento Europeu. Sua esfera de atuação recai sobre todos os membros da comunidade, especialmente no que se refere à "má-administração", expressamente consignada como objeto central de sua atuação. Ao ombudsman europeu deverão estar vinculados todos os ombudsman dos países membros, criando, desse modo, um complexo sistema de proteção ao cidadão. (CAMARGO e GOMES 2000)

\subsection{O Ombudsman na América Latina}

Na América Latina, a instituição do ombudman teve sua influência a partir da experiência da Espanha, que igualmente contempla a defesa dos direitos humanos.

CAMARGO e GOMES (2000), afirmam que a aceitação do instituto do ombudsman na América Latina e no Caribe não foi menor. Cerca de 17 países já implantaram oficinas de defensores ou ouvidores, todas, após 0 período de democratização do Continente, iniciado na década de 80 .

O primeiro país na região a instituir o ombudsman foi Trinidad Tobago, em 1976. Foi indicado pelo Presidente, após consulta ao primeiro ministro e ao líder da oposição. O ombdsman possui mandato de cinco anos. A segunda iniciativa foi da Guatemala, nove anos depois (1985), com a instituição do Procurador de los Derechos Humanos. A partir da experiência guatemalteca, o instituto se estendeu para o México (1990), El Salvador 
(1991), Colômbia (1991), Costa Rica (1992), Honduras (1992), Argentina (1993), Bolívia (1994), Nicarágua (1995), Peru (1996), Panamá (1997), Venezuela (1999), Guiana (s/data), Equador (s/data). (CAMARGO e GOMES, 2000)

CAMARGO e GOMES (2000) complementam, ao afirmar que sobressai, como um traço comum do instituto na América Latina, a tutela expressa aos direitos humanos. Talvez, em face dessa característica, a legitimidade de acesso ao ombudsman do continente latino americano, alcance em geral além dos cidadãos no gozo de todos os direitos - também os estrangeiros, reclusos e detentos, pacientes internos em estabelecimentos psiquiátricos, menores etc. (p. 60)

\subsection{A Experiência Brasileira}

No Brasil têm-se relatos de experiências nesta área que remontam à colonização. Conforme LACERDA (2000), em 1548 o ouvidor-mor foi um dos personagens de destaque da administração do Brasil, então centrada na Bahia. A ouvidoria geral de São Paulo foi criada em 1699 e regimentada em janeiro de 1700, sendo nomeado seu primeiro titular Antonio Luis Peleja. Mas, foi Rafael Pires Pardinho o ouvidor geral de maior destaque em São Paulo. As atribuições do ouvidor geral estavam previstas no corpo de direito então vigente em Portugal e, por extensão, no Brasil. Nesse período, sua competência passou a ser incorporada a do corregedor, mas a presença deste excluía a capacidade jurisdicional do ouvidor geral.

Citando LACERDA (2000), os poderes que os ouvidores tinham nas capitanias, eram de "representantes dos donatários, tocava-Ihes dirigir a eleição dos juizes e oficiais das câmaras vilarejas, apurando-Ihes as pautas, aos eleitos expedindo os respectivos títulos; pertencia-Ihes conhecer em grau recursal matéria criminal no perímetro de toda a capitania, e em caráter inicial no raio de dez léguas em torno do lugar em que a cada momento se encontrassem. No cível, despachavam para a capitania inteira, concedendo apelação e agravo em causas de valor acima de cem mil reais para 0 governo dela, instância definitiva." (p.14)

Acontece um intervalo de tempo, entre a instituição do primeiro Ouvidor do Brasil - Colônia, até a década de 1960, quando começa a 
despontar interesse sobre o tema, sendo elaborado o Decreto Federal no. 50.533 , de 1961, porém, revogado antes mesmo de ser colocado em prática. Este implantaria nas capitais dos Estados Sub-gabinetes da Presidência da República, com a atribuição, entre outras, de encaminhar aos órgãos pertinentes da administração federal "reclamações, pedidos e papéis de interesse das populações locais". (CAMARGO e GOMES 2000)

Todavia, CAMARGO e GOMES (2000) afirmam em 1977, dez anos após a reforma administrativa levada a efeito pela Edição do Decreto-Lei no. 200, a Comissão de Valores Mobiliários do Ministério da Fazenda criou no seu quadro de pessoal um cargo de ombudsman, que também não chegou a ser preenchido.

O regime militar que se implantou no Brasil em 1964 havia obstruído completamente os canais formais e informais de controle da Administração Pública que ligavam à sociedade civil. A censura à imprensa, ao teatro, ao cinema, aos livros, às organizações sociais (como sindicatos e partidos políticos), enfim, a qualquer tipo de oposição, acabaram por legitimar, com raras exceções, apenas modalidades intra-orgânicas de controle da Administração Pública. (CAMARGO e GOMES, 2000)

Por fim, na década de 1980, surgem várias propostas de implantação da figura do ombudsman, inclusive apresentadas ao Congresso Nacional, como por exemplo, a do Professor Afonso Arinos, que enquanto Presidente da Comissão Provisória de Estudos Constitucionais, elaborou um anteprojeto, no processo constituinte, tornando-se o Decreto no. 91.450 , de 18 de julho de 1985, o qual propôs expressamente a implantação da ouvidoria, denominada de "Defensoria do Povo:

"Art. 56 - É instituído o Defensor do Povo, incumbido, na forma de lei complementar, de zelar pelo efetivo respeito dos poderes do Estado aos direitos assegurados nesta Constituição, apurando abusos e omissões de qualquer autoridade e indicando aos órgãos competentes as medidas necessárias a sua correção ou punição.

$\S$ O Defensor do Povo poderá promover a responsabilidade da autoridade requisitada no caso de omissão abusiva na adoção das providências requeridas.

§ Lei complementar disporá sobre a competência, a organização e o funcionamento da Defensoria do Povo, observados os seguintes princípios:

I - o Defensor do Povo é escolhido, em eleição secreta, pela maioria absoluta dos membros da Câmara dos Deputados, entre 
candidatos indicados pela sociedade civil e de notório respeito público e reputação ilibada, com mandato renovável de cinco anos;

II - são atribuídos ao Defensor do Povo a inviolabilidade, os impedimentos, as prerrogativas processuais dos membros do Congresso Nacional e os vencimento dos ministros do Supremo Tribunal Federal;

III - as Constituições Estaduais poderão instituir a Defensoria do Povo, de conformidade com os princípios constantes deste artigo."

Com o fortalecimento do processo de defesa do consumidor iniciada com a inscrição, na Constituição Federal de 1988, expressamente colocado no Inciso $\mathrm{V}$, do artigo 170 , e que culminaria com a promulgação da Lei no. 8.078, de 11 de setembro de 1990, conhecida como Código de Defesa do Consumidor - "CDC", em atendimento ao que dispōe o artigo 48 das Disposições Transitórias da mesma Constituição, diversas empresas passaram a adotar a instituição da figura do Ombudsman. [www.aneel.gov.br/210.htm]

DALLARI (2000) entende que o Código de Defesa do Consumidor trata-se de uma regra geral, aplicável a todo o território Nacional, para disciplinar as relações de consumo. É importante notar que, em seu caráter de lei-quadro, o Código de Defesa do Consumidor se preocupa em construir uma nova cultura de respeito ao consumidor, o elo mais fraco na relação de consumo. Ainda, afirma Dallari, que o interesse do legislador, ao estabelecer o Sistema Nacional de Defesa do Consumidor, contudo, longe de provocar disputas por atribuições, foi instituir uma nova cultura de proteção e defesa do elo mais fraco da relação de consumo: o consumidor.

Os últimos anos do século $X X$ e início do século $X X I$ mostram que na realidade brasileira ocorreu uma divisão na terminologia: o termo ouvidor prevalece na esfera pública como o representante do cidadão, ficando o termo ombudsman reservado às empresas da iniciativa privada, onde costuma significar representante do cliente, representante do funcionário ou representante do consumidor. (PINSKI, 2003)

Como primeira experiência, nos setor privado, temos o Jornal "Folha de São Paulo" que em 1989, instituiu o cargo de Ombudsman, divulgando seu significado, e, com a promulgação do Código de Defesa do Consumidor em 1990, outras empresas e instituições fizeram o mesmo. Assim, em seguida, a ABINEE - Associação Brasileira da Indústria Elétrico e Eletrônica, 
- Banco Nacional e o Grupo Pão de Açúcar também adotaram seus Ombudsman. (VISMONA 1998 p. 1)

Esta função foi adotada pela iniciativa privada, visando conferir uma maior transparência às suas atividades e, também, estimular o consumidor a defender seus direitos e interesses junto à instituição, privilegiando a prevenção e, por conseqüência, evitando confrontos nas relações de consumo. Assim, a empresa se posicionaria melhor no mercado, aperfeiçoaria a qualidade de seus produtos e serviços e criaria um canal importante de comunicação direta com o consumidor. (VISMONA 1998, p.1)

No âmbito da esfera pública, a adoção do papel do Ombudsman, ou como é denominado nesta área, o Ouvidor, teve uma evolução mais lenta. Curitiba, Maringá e posteriormente, todo o Estado do Paraná, adotaram esta função, seguidos por outras cidades e estados brasileiros, dentre eles: Santos e Campinas, seguidas por todo o Estado de São Paulo e Fortaleza, posteriormente, todo o Estado do Ceará. Além de cidades e Estados, diversos órgãos públicos, como a Secretaria de Segurança Pública do Estado de São Paulo, a Fundação PROCON, órgão de proteção ao consumidor, e o IPEM - Instituto de Pesos e Medidas, assim como, empresas públicas prestadoras de serviços, também seguiram este caminho. Este crescimento foi movido pela necessidade de atender o cidadão e aperfeiçoar os serviços e produtos, mas também, representa uma inequívoca conscientização da cidadania, que cada vez mais exige respeito aos direitos e participação social. (VISMONA 1998)

\subsection{A Ouvidoria na Área da Saúde: Bases Legais}

A ouvidoria na área de saúde tem seu início na introdução da Lei $n^{0 .}$ 8.080 de 19 de setembro de 1990, a qual dispõe sobre as condições para a promoção, proteção e recuperação da saúde, a organização e 0 funcionamento dos serviços correspondentes e dá outras providências.

O Art. $2^{2}$ ๆ $2^{2}$ estabelece que o dever do Estado de garantir a saúde consiste na reformulação e execução de políticas econômicas e sociais que visem à redução de riscos e doenças e de outros agravos no estabelecimento 
de condições que assegurem acesso universal e igualitário às ações e aos serviços para a sua promoção, proteção e recuperação. “

Em seu Capítulo II - Dos Princípios e Diretrizes - Art. $7^{0}$ - Princípios: a Lei 8080/90 trata da: (i) IV - igualdade da assistência à saúde, sem preconceitos ou privilégios de qualquer espécie; (ii) V - Direito à informação, às pessoas assistidas, sobre sua saúde; (iii) VI - Divulgação de informações quanto ao potencial dos serviços de saúde e sua utilização pelos usuários, (v)

VIII - Participação da comunidade;

No Art. $15^{\circ}$ - A União, os Estados, o Distrito Federal e o Municípios exercerão, em seu âmbito administrativo, dentre várias atribuições como: I. definição das instâncias e mecanismos de controle, avaliação e fiscalização das ações e serviços de saúde.

A criação de ouvidorias enquanto mecanismo de controle, buscando assegurar o acesso universal e igualitário às ações e aos serviços.

A Lei $8080 / 90$ é de grande importância, não somente por toda a contribuição que trouxe e ainda traz para a área da saúde, mas, também, por promover reflexões e ações através de canais de comunicação e participação ativa do cidadão, imprescindíveis para o resgate da cidadania no que tange uma das áreas mais importantes da vida, a saúde.

Consoante ao tema abordado, têm-se a Lei no. 3.507, de 13 de Junho de 2000 , que dispõe sobre o estabelecimento de padrões de qualidade do atendimento prestado aos cidadãos pelos Órgãos e pelas Entidades da Administração Pública Federal direta, indireta e fundacional trazendo em seu Artigo $3^{\circ}$ - que os órgãos públicos deverão estabelecer padrões de qualidade e criar mecanismos de comunicação com o usuário e procedimentos para o atendimento de reclamações, bem como procedimentos que viabilizem ao usuário acompanhar sua reclamação.

No mais, cabe destacar, a Portaria no. 1.112, de 29 de setembro de 2000 do Ministério da Saúde que instituiu o Grupo de Acompanhamento da Responsabilização - GAR - decorrente de ações levadas a efeito pelo controle externo e interno da Administração e reclamações dos usuários do SUS, promovendo articulação entre as instâncias de controle, de responsabilização, de controle social e de gestão da saúde nos planos federais, estaduais e municipais. 
Em 2001, o Ministro da Saúde elaborou o Manual Técnico para Implantação dos Padrões de Qualidade de Atendimento ao Cidadão, que teve por finalidade promover a melhoria da qualidade do atendimento prestado pelos órgãos entidades do Serviço Público Federal e satisfazer as necessidades dos usuários. No Artigo IV - Participação do Cidadão - enfatiza a importância do estimulo da participação do cidadão, e para efetivá-la, propõe criação de canais de comunicação tais como ouvidorias, através dos quais os cidadãos tenham seus direitos assegurados, podendo exercer sua cidadania, através de reivindicações, que deverão ser acolhidas e atendidas.

Através do Decreto no. 4.726 de 9/06/2003, criou-se a Ouvidoria Geral do SUS, a partir dos seguintes serviços pré-existentes: Serviço Disque Saúde, Serviço de Atendimento ao Cidadão Usuário do SUS e Centro Nacional de Promoção da Qualidade e Proteção ao Usuário do Sistema Único de Saúde ("SUS"). Um de seus objetivos é propor, coordenar e implementar a Política Nacional de Ouvidoria em Saúde no âmbito do SUS, Buscando integrar e estimular práticas que ampliem o acesso dos usuários ao processo de avaliação das ações e serviços públicos de saúde. (Art. 28) (Brasil, 2005)

Em 16 de junho de 2004, o Ministério da Saúde, institui a Portaria no. 1.193, que disciplina o funcionamento do Departamento de Ouvidoria-Geral do Sistema Único de Saúde, que visa centralizar o recebimento das denúncias formuladas por servidores e cidadãos interessados, relativamente às atividades e aos procedimentos internos, no âmbito do Sistema Único de Saúde - SUS.

Porém, em 13 de julho de 2006, o Decreto Presidencial $n^{0} 5.841$ revogou o Decreto anterior e aprovou a nova estrutura regimental e o quadro demonstrativo dos cargos em comissão e das funções gratificadas do Ministério da Saúde, definindo também as atribuições e competências do Departamento de Ouvidoria Geral do SUS.

\subsection{A Criação das Ouvidorias no Estado de São Paulo}

Em São Paulo, a primeira lei que tratou dessa questão, de forma indireta, foi a Lei $n^{\text {o. }} 10.177$ de 30 de dezembro de 1998 que dispõe em seu 
artigo 23 a necessidade de assegurar a qualquer pessoa, física ou jurídica, independentemente de pagamento, o direito de petição contra ilegalidade ou abuso de poder, assim como, a defesa de seus direitos. Sendo que, o direito de petição, pode ser exercido de forma individual ou coletiva, através de pessoa física ou jurídica.

\subsubsection{Lei 10.294/99: Algumas Considerações}

A Lei de Proteção e Defesa do Usuário foi elaborada como instrumento de controle interno, instituindo um sistema de Ouvidorias na Administração Pública Estadual. Todos os órgãos públicos estaduais, diretamente envolvidos com a prestação de serviços e o atendimento do cidadão devem ter um ouvidor. (VISMONA 2001)

As normas desta lei visam à tutela dos direitos do usuário e aplicam-se aos serviços públicos prestados pelos órgãos estaduais.

A Lei entende como direitos básicos dos usuários:

- Informação;

- Qualidade na prestação do serviço

- Controle adequado do serviço público

Cria-se o Sistema Estadual de Defesa de Serviços Públicos SEDUSP, o qual tem por objetivo instituir e assegurar um canal de comunicação direto entre os prestadores de serviços e os usuários, a fim de aferir o grau de satisfação desses últimos e estimular a apresentação de sugestões. Integram, o SEDUSP:

- Ouvidorias;

- Comissões de Ética;

- Comissão de Centralização de Informações dos Serviços Públicos do Estado de São Paulo, com representação dos usuários, com finalidade de sistematizar e controlar todas as informações relativas aos serviços especificadas nesta lei, facilitando o acesso aos dados colhidos; e (iv) Os órgãos encarregados do desenvolvimento de programas de qualidade do serviço público; 
Posteriormente, a lei foi regulamentada pelo Decreto $n^{0 .} 43.958$, de 20 de Abril de 1999, que institui uma Comissão Intersetorial para propor providências visando à sua implantação. Também, o Decreto $n^{0 .} 44.074$, de $1^{\circ}$ de Julho de 1999, regulamenta a composição e estabelece as competências das Ouvidorias de Serviços Públicos Estaduais.

Sendo um instituto ligado ao Poder Executivo, compete a cada Secretaria de Estado definir o perfil do seu ouvidor, conforme seus órgãos, atribuições, usuários e serviços prestados, sendo importante que o cidadão sempre que queira se manifestar encontre através de um Ouvidor um canal de comunicação e representação de sua queixa, reclamação ou elogio.

O Decreto estabelece objetivos, competências e atribuições do Ouvidor de Serviços Públicos Estaduais:

\subsubsection{Objetivos da Ouvidoria}

- Receber e investigar as queixas de cidadãos, com relação ao mau atendimento em órgãos públicos, por abusos e erros, se assim entender procedentes e procurar soluções;

- Atuar na melhoria da qualidade do serviço prestado;

- Garantir os direitos do cidadão usuário do serviço público

\subsubsection{Competências da Ouvidoria}

- Receber reclamações, solicitações, sugestões e demandas provenientes dos usuários de serviços públicos estaduais;

- Representar os cidadãos junto à instituição em que atuam, viabilizando um canal de comunicação; e

- Defender os interesses das partes, sendo imparcial em sua atuação.

\subsubsection{Atribuições da Ouvidoria}

- Receber reclamações, solicitações e sugestões dos cidadãos, através de carta, telefone, fax, e-mail ou pessoalmente. 
- Analisar as reclamações e emitir pareceres, encaminhar e/ou acionar os meios institucionais no Estado no sentido de que providências sejam tomadas.

\subsection{A Ouvidoria na Saúde no Estado de São Paulo}

Além da legislação supra citada, têm-se ainda, o Código de Saúde do Estado de São Paulo (Lei Complementar no. 791/95), que estabelece em seu Capítulo III, Seção V: "Da Ouvidoria Geral" - Artigo 36, que sem prejuízo da competência do dirigente do SUS e da atuação dos órgãos de controle externo e interno e do Conselho Estadual de Saúde, haverá, na direção do SUS estadual, uma Ouvidoria Geral, incumbida de detectar e receber reclamações e denúncias, encaminhando-as aos órgãos competentes para as providências necessárias."

A aplicabilidade desta legislação desencadeou o processo de instituição de ouvidorias em equipamentos de saúde de responsabilidade da esfera Estadual.

\subsection{A Ouvidoria no Município de São Paulo}

Em 2001, o Município de São Paulo, através de Decreto Municipal no. 40.248, instituiu na cidade de São Paulo, junto ao Gabinete da Prefeita, a Ouvidoria Geral do Município de São Paulo. A Ouvidoria tem como atribuições receber e apurar denúncias, reclamações e representações sobre atos considerados ilegais, arbitrários, desonestos, ou que contrariem o interesse público, quando praticados por servidores públicos do Município de São Paulo, empregados da Administração Indireta, agentes políticos, ou por pessoas, físicas ou jurídicas, que exerçam funções paraestatais, mantidas com recursos públicos.

Uma das prioridades da Ouvidoria no âmbito municipal é sistematizar informações recebidas do munícipe e dos vários canais ligados à administração municipal. A partir do conhecimento detalhado dos serviços nas diversas regiões do município, a Ouvidoria elabora sugestões que visam elevar a qualidade dos serviços e ampliar seu acesso à população, além de 
aumentar o conhecimento dos cidadãos acerca de seus direitos e deveres. [http://portal.prefeitura.sp.gov.br/ouvidoria/atribuicoes/0001]

Com base no trabalho de Ouvidoria da Prefeitura, o órgão pretende atuar cada vez mais como mediador na definição de políticas públicas e colaborar com a eficácia das ações governamentais. [http://portal.prefeitura.sp.gov.br/ouvidoria/atribuicoes/0001]

\subsection{As Três Esferas de Governo: Federal, Estadual e Municipal}

Segundo DALLARI (2007), a teoria da separação de poderes, que através da obra de Montesquieu se incorporou ao constitucionalismo, foi concebida para assegurar a liberdade dos indivíduos.

$\mathrm{Na}$ Constituição Federal (1988), do Título III: Da Organização do Estado, elabora:

Art.18. A organização política-administrativa da República Federativa do Brasil compreende a União, os Estados, o Distrito Federal e os Municípios, todos autônomos, nos termos da Constituição.

DALLARI (2007), afirma que o sistema de separação dos poderes, consagrado nas Constituições de quase todo o mundo, foi associado à idéia de Estado Democrático.

Sucintamente, DALLARI (2007) expõe da seguinte forma a ação dos três níveis de governo:

\footnotetext{
"Os atos gerais, que só podem ser praticados pelo Poder Legislativo, constituem-se a emissão de regras gerais e abstratas, não se sabendo, no momento de serem emitidas, à quem elas irão atingir. Dessa forma o Poder Legislativo, que só pratica atos gerais, não atua concretamente na vida social, não tendo meios para cometer abusos de poder nem para beneficiar ou prejudicar a uma pessoa ou a um grupo em particular. Só depois de emitida a norma geral é que se abre a possibilidade de atuação do poder executivo, por meio de atos especiais. O Executivo dispõe de meios concretos, para agir, mas está igualmente impossibilitado de atuar discricinariamente, porque todos os seus atos estão limitados pelos atos gerais praticados pelo Legislativo. E, se houver exorbitância de qualquer dos poderes surge a ação fiscalizadora do Poder Judiciário, obrigando cada uma a permanecer nos limites de sua respectiva esfera de competências."
} 
Nosso campo de pesquisa serão as ouvidorias nos três níveis da saúde: Ouvidoria Geral do SUS, Ouvidoria do Estado da Saúde de São Paulo, e duas Ouvidorias de Secretarias Municipais de Saúde. 


\section{JUSTIFICATIVA}

Enquanto contato com o tema, relato que em 2000, trabalhei como assistente social em uma Unidade Básica de Saúde na Cidade de São Paulo. Naquela época era uma Unidade Básica da gestão Estadual. Neste mesmo ano anexaram nas paredes da UBS, cartazes com dizeres sobre "ouvidoria na saúde" e um número 0800 para contato. Não me recordo de nenhum esclarecimento sobre o assunto. Tenho a impressão que neste momento, efetivamente, nenhum movimento aconteceu e que o gestor, os profissionais da saúde e os usuários não entendiam qual o significado daquele cartaz.

No decorrer dos anos e devido a mudanças de local de trabalho e também do gestor central -- a saúde foi municipalizada em São Paulo, a partir de 2001 -- continuei a encontrar em diversas unidades e em outros equipamentos de saúde cartazes da ouvidoria. Inquiri algumas pessoas sobre o assunto, mas as respostas não passavam de conjecturas. Naquela época, muitas vezes, o ouvidor era representado pelo próprio gerente da unidade o que possivelmente dificultava e até mesmo intimidava o usuário no seu acesso a ouvidoria.

Em 2003 recebi uma ligação que me fez despertar mais o interesse sobre o tema, abrindo uma nova perspectiva com relação a ouvidoria. A Diretora de um grande hospital público da Cidade de São Paulo a qual nunca tive contato pessoalmente, mas que de alguma forma, instigou-me a estudar o tema ao me convidar a assumir a ouvidoria deste hospital.

O entendimento desta profissional sobre a ouvidoria era que este canal deveria ser amplo e o ouvidor fosse um profissional independente e autônomo, tanto em relação à instituição, quanto em relação ao usuário, para que não gerasse grandes conflitos de interesse em ambas as partes. Outra ponderação muito importante foi que a partir das reclamações dos usuários novas ações administrativas pudessem ser discutidas, pensadas, e reestruturadas, buscando-se assim, a qualidade do serviço dentro dos limites da administração pública. 
Infelizmente, por motivos pessoais, não foi possível assumir este desafio, mas este telefonema resultou nesta minha inquietação e reflexão, hoje efetivada através deste trabalho.

Todavia, esta experiência pessoal me incentivou a estudar a questão. A Ouvidoria no setor saúde constitui-se em prática recente nos três níveis de governo: Federais, Estaduais e Municipais, sendo a literatura nacional sobre o tema é bastante escassa. Por isto, a tentativa de caracterizar e descrever experiências recentes ocorridas nos três níveis de gestão pode contribuir para a reflexão sobre o tema e incentivar novas pesquisas. 


\section{OBJETIVO}

\subsection{Objetivo Geral}

Caracterizar e descrever experiências de ouvidorias de saúde nos três níveis de gestão: Federal, Estadual e Municipal. 


\section{METODOLOGIA}

\subsection{Procedimentos Metodológicos}

Pela natureza do problema proposto neste estudo, optamos pela abordagem qualitativa, como método de investigação. Entende-se que esta abordagem auxiliará no cumprimento dos objetivos propostos.

Conforme GIL (1985) as pesquisas exploratórias são desenvolvidas com o objetivo de proporcionar uma visão geral do tipo aproximativo, acerca de determinado fato. Este tipo de pesquisa é realizada, especificamente quando o tema escolhido é pouco explorado e torna-se difícil sobre ele formular hipóteses precisas e operacionalizáveis.

Segundo WESTPHAL (1992), as metodologias qualitativas garantem maior liberdade ao pesquisador, para captar a dinâmica e a profundidade das relações presentes no fenômeno pesquisado, que pretendemos alcançar.

LUDKE e ANDRÉ (1986), afirmam que a abordagem qualitativa tenta captar a realidade dinâmica e complexa do seu objeto de estudo no seu contexto histórico. Tem o ambiente social como fonte de dados, e estes se apresentam predominantemente explicativos. O processo é mais importante do que o produto. $O$ foco de atenção do pesquisador está no significado que as pessoas dão às coisas e à sua vida. Preocupa-se em retratar a perspectiva dos participantes e a análise dos dados tende a seguir um processo indutivo.

Como estudo de múltiplos casos, foram escolhidas a Ouvidoria de Saúde do Ministério da Saúde, a Ouvidoria da Saúde da Secretaria de Estado da Saúde e as Ouvidorias de dois municípios do Estado de São Paulo. Municípios de grande porte, com tempo de funcionamento maior de dois anos, com ouvidores com grande experiência em administração pública.

Após aprovação do projeto pelos devidos Comitês de Ética, iniciou-se a coleta de dados documentais acessando os sites das ouvidorias estudadas e realizou-se entrevistas com as pessoas-chave: Ouvidor do Ministério da Saúde ("Ouvidor Geral do SUS"), Secretaria do Estado da Saúde de São Paulo ("Ouvidor do Estado SES/SP"), e de duas Secretarias Municipais de 
Saúde, M-1 e M-2, respectivamente, não identificadas a pedido dos entrevistados.

Com relação ao estudo buscou-se caracterizar os sites, da Ouvidoria Geral do Ministério da Saúde, da Ouvidoria da Secretaria de Estado da Saúde e das duas ouvidorias de municipais - M-1, M-2 por entender que os mesmos são canais de grande importância para o acesso e participação social do cidadão.

Efetuou-se, um levantamento da forma de organização da ouvidoria nos locais selecionados para o estudo, levando-se em conta a estrutura organizacional dos locais escolhidos dentro dos sites identificando as formas de contato apresentadas.

\subsection{Entrevistas com os Ouvidores da Saúde}

Segundo LUDKE e ANDRÉ (1986) e TRIVIÑOS (1987) a entrevista é uma das principais técnicas de trabalho utilizadas nas ciências sociais e representa um dos instrumentos básicos de coleta de dados dentro da perspectiva da pesquisa qualitativa. Adquire destaque por ser uma técnica, confiável, transparente e ética, quando observados todos os cuidados necessários para sua aplicação.

A entrevista semi-estruturada pressupõe um roteiro básico que permite ao entrevistador promover adaptações no desenvolver da mesma, de acordo com as necessidades. Ela mantém a presença consciente e atuante do pesquisador, ao mesmo tempo em que permite a relevância na situação do ator. Isto favorece não só a descrição dos fenômenos sociais, mas também sua explicação e a compreensão de sua totalidade, tanto dentro de sua situação específica como de situações mais complexas. (TRIVIÑOS, 1987).

Utilizou-se a técnica de entrevista semi-estruturada, facilitando a expressão dos entrevistados, conforme roteiro, contendo as seguintes questões:

- Quanto tempo de prática como ouvidor na área da saúde?

- Comente sobre sua história pessoal. Como chegou à função de ouvidor?

- Comente sobre o papel do ouvidor nesta instituição de saúde. 
- Quais as ações desenvolvidas pela ouvidoria nesta instituição?

- O que considera importante para que o papel do ouvidor da saúde se estabeleça?

O procedimento básico para o tratamento do material coletado foi à análise do conteúdo da informação colhida, através da categorização do teor selecionado, segundo suas características, causas e efeitos. (CARTWRIGHT, 1976, in FESTINGER, L. e KATZ, D.)

\subsubsection{Entrevista com Ouvidor Geral do Ministério da Saúde - "Ouvidor Geral do SUS"}

Efetuou-se entrevista com o Ouvidor Geral do Ministério da Saúde. Na época da entrevista o então Ouvidor Geral do SUS havia assumido a Ouvidoria do Ministério da Saúde há menos de um ano sendo que a mesma ficou por mais de dois anos sem ouvidor nomeado, funcionando somente através do acesso do 0800.

Ressalta-se que a entrevista com o Ouvidor Geral do SUS teve como intuito compreender o momento pelo qual a Ouvidoria Geral do Ministério da Saúde estava sendo estabelecida e como estavam sendo discutidas as políticas nesta área.

Entender como se estabelece a Ouvidoria Geral do Ministério da Saúde torna-se fundamental, pois a política desta Ouvidoria Geral, contribui com diretrizes para o funcionamento de ouvidorias em outras esferas de governo, seja estadual ou municipal, bem como, as ouvidorias institucionais.

\subsubsection{A Ouvidoria Geral do SUS}

Antes da reforma constitucional de 1988, o sistema de saúde brasileiro era fortemente centralizado e mostrava pouca atenção às atividades de prevenção e de assistência sanitária. Em 1986, realizou-se a VIII Conferência Nacional de Saúde, um evento de grande relevância nacional, que mobilizou amplos setores da sociedade civil. A Constituição Federal de 1988 incorporou grande parte das propostas elaboradas pela Conferência e instituiu o Sistema Único de Saúde (SUS). Em 1990, foram publicadas Leis (8.080 e 8.142) para implementar o SUS e seus princípios fundamentais. Como instância de 
participação da população, foram criados os Conselhos de Saúde e as Conferências de Saúde. (SERAPIONI, ROMANÍ, 2006)

Em 1990, o Congresso Nacional aprovou a Lei Orgânica da Saúde que detalha o funcionamento do Sistema, desvinculando assim o Ministério da Saúde e Previdência Social, tornando-o mais autônomo e com financiamentos próprios.

Atualmente o Ministério da Saúde trabalha com o conceito ampliado de saúde, focando os modelos de atenção que são: promoção, proteção e recuperação da saúde, competindo ao Ministério as seguintes atribuições:

- Desenvolver política nacional de saúde;

- Coordenar e fiscalizar o Sistema Único de Saúde;

- Atender as questões relativas à saúde ambiental e ações de promoção, proteção e recuperação da saúde individual e coletiva, inclusive a dos trabalhadores e dos índios;

- Prover informações de saúde;

- Prover insumos críticos para a saúde;

- Desencadear ação preventiva em geral, vigilância e controle sanitário de fronteiras e de portos marítimos, fluviais e aéreos;

- Promover a vigilância de saúde, especialmente drogas, medicamentos e alimentos;

- Desenvolver e controlar pesquisa científica e tecnologia na área de saúde.

Em janeiro de 2006, houve uma reformulação da estrutura do Ministério da Saúde, designada de "Estrutura Regimental Básica", aprovada pelo Decreto nº 5.678 de 18/01/2006.

\subsubsection{A Criação da Ouvidoria Geral do SUS}

$\mathrm{Na}$ área da saúde instituiu-se a Ouvidoria Geral do SUS, por meio do Decreto Presidenciável no. 4.726 de 9/6/2003, conforme descrito na introdução deste estudo que tinha como objetivo principal integrar e estimular práticas que ampliem o acesso dos usuários ao processo de avaliação das ações e serviços públicos de saúde. 
Em 13 de julho de 2006, o Decreto Presidencial no 5.841 revogou o Decreto Presidenciável no. 4.726/03, aprovando a nova estrutura regimental e o quadro demonstrativo dos cargos em comissão e das funções gratificadas do Ministério da Saúde, definindo também as atribuições e competências do Departamento de Ouvidoria Geral do SUS, efetivando assim, a subordinação da Ouvidoria à Secretaria de Gestão Estratégica e Participativa, cuja função é formular e coordenar a Política de Ouvidoria para o SUS, implementando sua descentralização e cooperação com entidades em defesa de direitos dos cidadãos. (Brasília, MS, 2006).

A Ouvidoria Geral do SUS incorpora em seu papel atual, através do Departamento de Ouvidoria Geral do SUS - DOGES, informações sobre saúde prestada pelo departamento. Atualmente, através do número 080061 1997, pode-se acessar todos os serviços e informações que antes eram prestadas pelos diversos 0800 administrados pelo Ministério da Saúde. [http://portal.saude.gov.br/portal/saúde - acesso em 03/11/2006]

O atual Ouvidor Geral do Ministério da Saúde foi convidado a ocupar o Cargo, pelo então Ministro Interino da Saúde, Dr. Agenor Álvares. 


\section{ORGANOGRAMA DA OUVIDORIA GERAL DO SUS MINISTÉRIO DA SAÚDE}

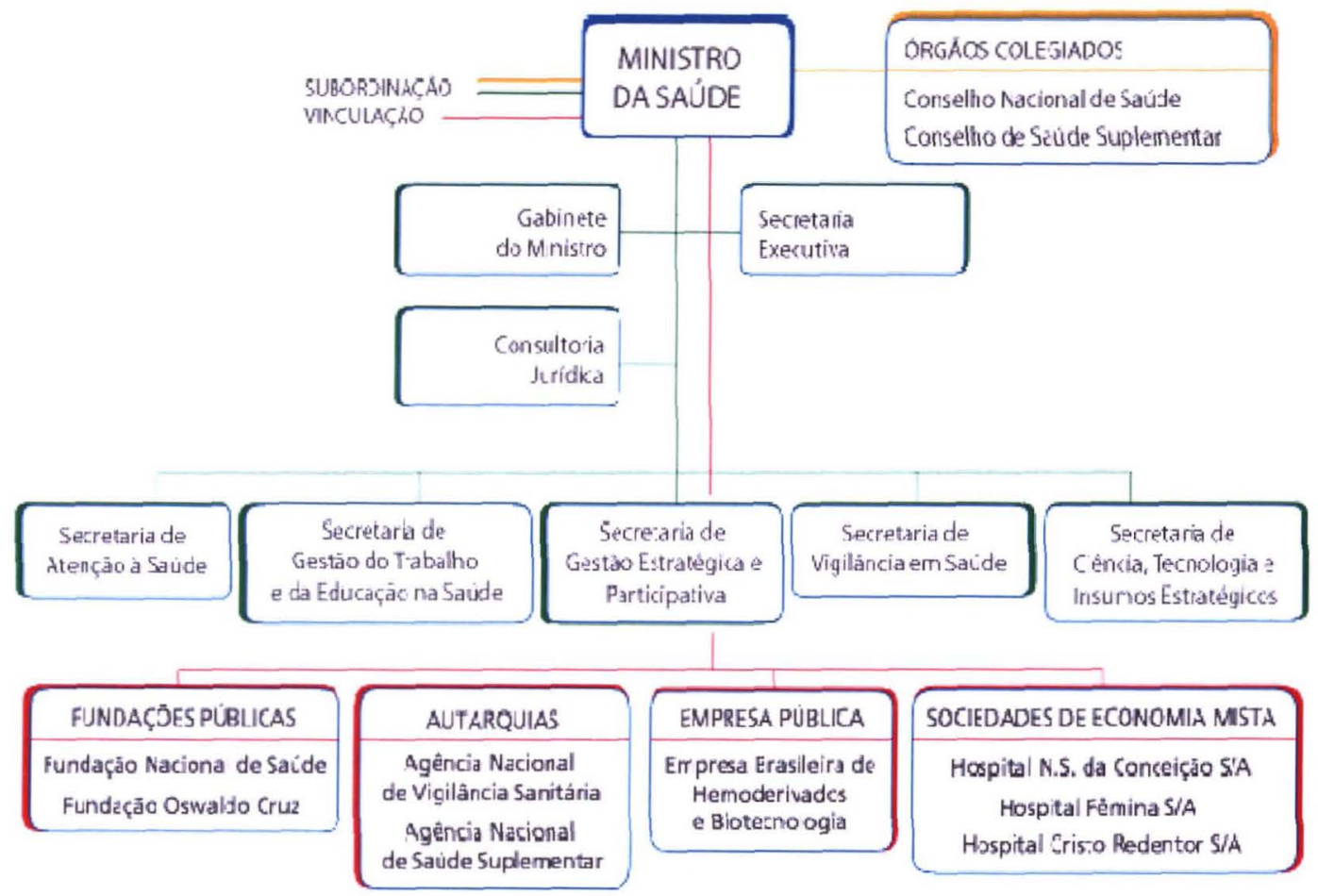

Fonte: [http://portal.saude.gov.br/portal/aplicacoes/tabfusion/tabfusion.cfm - acesso em abril/2007].

\subsubsection{Localização da Ouvidoria Geral do SUS}

A Ouvidoria Geral do SUS localiza-se, junto à Secretaria de Gestão Estratégica e Participativa - "SEGEP", que foi criada pelo Decreto $n^{9} 4.726$, de 09 de junho de 2003, que aprovou a Estrutura Regimental do Ministério da Saúde. Teve como seu primeiro titular o médico sanitarista Sérgio Arouca reconhecimento a sua enorme contribuição à criação e desenvolvimento do Sistema Único de Saúde - SUS. [http://portal.saude.gov.br/portal/saude/area.cfm?id_area=384 - acesso em abril de 2007]

Após sua reestruturação, finalizada em julho de 2006 a SEGEP passou a incorporar novas funções, como a educação popular em saúde, o monitoramento, a avaliação e a auditoria do SUS, somando-se às áreas de incentivo à participação social e de ouvidoria já existentes. 
Sua estrutura de atenção e atuação abrange os seguintes departamentos:

- Departamento de Apoio à Gestão Participativa

- Departamento de Monitoramento e Avaliação da Gestão do SUS

- Departamento de Ouvidoria-Geral do SUS

- Departamento Nacional de Auditoria do SUS

A Secretaria de Gestão Estratégica e Participativa tem como competência com relação a Ouvidoria Geral do SUS:

"X - formular e coordenar a Política de Ouvidoria para o SUS, implementando sua descentralização e cooperação com entidades de defesa de direitos do cidadão".

A Secretaria de Gestão Estratégica e Participativa propõe coordenar e apoiar a implementação da Política Nacional de Gestão Participativa em Saúde, conforme abaixo:

"ll - criar e implementar mecanismos de apoio ao processo de organização e funcionamento do Controle Social do SUS;

III - fomentar a participação de trabalhadores e usuários na tomada de decisões na gestão do SUS;

IV - apoiar processos de qualificação e efetivação do controle social do SUS;

$V$ - contribuir para a promoção da eqüidade em saúde, acolhendo e articulando as demandas de grupos e populações socialmente excluídas;

VI - apoiar iniciativas dos movimentos sociais para o processo de formulação de políticas de gestão do SUS;

VII - fomentar e ampliar a mobilização social pelo direito à saúde e em defesa do SUS;

VIII - mobilizar e instrumentalizar gestores e trabalhadores de saúde para as práticas de gestão participativa;

IX - estabelecer mecanismos de educação e comunicação, em saúde, com a rede escolar, com as organizações não-governamentais e com os movimentos sociais; $e$

$X$ - viabilizar e coordenar a realização de estudos e pesquisas, visando à produção do conhecimento no campo da gestão participativa e do controle social. "[http://portal.saude.gov.br/portal/saude]

Encontra-se no manual de "Orientações para Implantação de Unidade de Ouvidoria da Presidência da República Controladoria-Geral da União e Ouvidoria-Geral da União", documento datado de 2004 o qual descreve a forma de implantação das ouvidorias, contribuindo também com um item 
chamado Vinculação da Ouvidoria, no qual encontra-se a seguinte informação:

"A ouvidoria e o cargo de ouvidor devem ser instituídos por ato normativo formal, com clara designação das atribuições, dos poderes e do âmbito de atuação.

O ouvidor deverá ser subordinado diretamente ao dirigente máximo do órgão/entidade, deste deverá receber o suporte necessário para 0 exercício de suas funcões, de forma que possa agir com imparcialidade e legitimidade junto aos demais dirigentes da Instituicão." (Presidência da República, 2004) (Grifos nossos)

Apesar de encontrar neste documento, informações sobre a vinculação das Ouvidorias Gerais, diretamente com o nível central na saúde Participativa. Entende o Ministério da Saúde, que a ouvidoria é um instrumento da democracia participativa devendo estar ligada ao controle social trazendo para dentro das decisões da gestão as avaliações, opiniões, as idéias geradas pelos usuários dos serviços públicos de saúde. Ou seja, a construção da Política Nacional de Ouvidoria para o SUS é um desafio institucional que deve mobilizar gestores, instâncias de controle social, trabalhadores em saúde e usuários dos serviços públicos. (Brasil, 2005).

A 10ª . Conferência Nacional de Saúde, ocorrida e elaborada em 1996, quase 10 anos após a implantação do Sistema Único de Saúde, emite parecer final favorável à implantação de Ouvidorias SUS “... os Conselhos Gestores do SUS devem constituir e implementar novos mecanismos de participação". Entre esses mecanismos incluem-se as ouvidorias e serviços de disque saúde em todos os níveis do SUS, vinculados aos Conselhos de Saúde. (p.35). (Grifos nossos)

Provavelmente esta hierarquização da Ouvidoria, juntamente com a Secretaria de Gestão Estratégica e Participativa, poderá de alguma forma, comprometer a autonomia de ação deste órgão. Entende-se que se a ouvidoria não for amplamente apoiada possivelmente correrá o risco de se perder em questões burocráticas e também ideológicas, não efetivando de fato o seu real papel que é representar o cidadão frente às questões da administração pública, bem como, tornar-se um importante instrumento de administração para o gestor. 
Abaixo as competências da Ouvidoria Geral do SUS:

Ao Departamento de Ouvidoria Geral do SUS, compete:

I - propor, coordenar e implementar a Política Nacional de Ouvidoria em Saúde, no âmbito do SUS;

II - estimular e apoiar a criação de estruturas descentralizadas de Ouvidoria em Saúde;

III - implementar políticas de estímulo à participação de usuários e entidades da sociedade no processo de avaliação dos serviços prestados pelo SUS;

IV - promover ações para assegurar a preservação dos aspectos éticos, de privacidade e confidencialidade em todas as etapas do processamento das informações decorrentes;

$V$ - assegurar aos cidadãos $o$ acesso às informações sobre $o$ direito à saúde e às ações relativas ao exercício desse direito,

VI - acionar os órgãos competentes para a correção de problemas identificados, mediante reclamações enviadas diretamente ao Ministério da Saúde, contra atos ilegais ou indevidos e omissões no âmbito da saúde; $e$

VII - viabilizar e coordenar a realização de estudos e pesquisas visando à produção do conhecimento, no campo da ouvidoria em saúde, para subsidiar a formulação de políticas de gestão do SUS “

\subsubsection{Disque Saúde - 0800611997}

O disque saúde vem ao encontro da ação da Ouvidoria Geral do SUS, conforme estabelecidas as ações do Departamento de Ouvidoria Geral do SUS cuja competência é:

"V ... assegurar aos cidadãos o acesso às informações sobre o direito à saúde e as ações relativas ao exercício desse direito, cumprindo, então com a implantação do 0800..."

O Disque Saúde tem seis opções de atendimento. O acesso a Ouvidoria SUS insere-se na Opção 4 - aborda denúncias, reclamações e sugestões ao Ministério da Saúde tendo como opções: Opção - 4.1. telefone das Secretarias Municipais de Saúde, Opção - 4.2 - voltar a menu principal; e Opção - 4.3 - para falar com atendentes“.

Em abril de 2006 estabelece-se o sistema Ouvidor Geral do SUS, uma importante ferramenta no processo de encaminhamento e avaliação das demandas encaminhadas a Ouvidoria. Esse sistema integrado em rede nacional, permite visualização e acompanhamento das demandas captadas 
pela Ouvidoria por toda a rede de gestores, profissionais e usuários do SUS [http://portal.saude.gov.br/portal/saúde]

O número 0800 disponibilizado pela Ouvidoria SUS possui uma abrangência mais voltada ao que se entende por SAC - Serviço de Atendimento ao Cidadão, privilegiando canais de informação sobre saúde e serviços.

CENTURIÃO (2003), afirma que o SAC poderá produzir estatísticas dos atendimentos prestados que serão objeto de análise, eventualmente dando origem a mudanças em rotinas e serviços. Todos esses instrumentos, esta rede de apoio, bem como, a ouvidoria, conforme afirma o Autor, tem a finalidade de facilitar a comunicação com os clientes, criando vínculos e contribuindo para a preservação da imagem da organização - seja ela uma empresa ou um órgão público.

O SAC ou SAU - Serviço de Atendimento ao Usuário deverá ser utilizado pela ouvidoria enquanto uma rede de apoio. Uma das funções da ouvidoria é informar, esclarecer e subsidiar o cidadão para uma melhor relação com a rede pública e ou privada.

\subsubsection{Ações da Ouvidoria Geral do SUS}

Atualmente, a Ouvidoria Geral do SUS trabalha com o slogan: "A Saúde Ouve Você: Informações, Denúncias, Reclamações e Sugestões. Você Fala e a Ouvidoria da Saúde Responde" que dispõe de canais de comunicação e de informação para o usuário.

A Ouvidoria trabalha integradamente ao Disque Saúde conforme anteriormente descrito, desenvolvendo um sistema de ações e informações sobre saúde e participação social, atualmente concentrada em um só número, para os vários acessos disponíveis no Disque Saúde.

\subsubsection{Acesso Via Internet}

No acesso através do site: www.portal.saude.gov.br, localiza-se facilmente o canal da ouvidoria, no qual encontra-se as seguintes informações: 


\section{- O que é a Ouvidoria Geral do SUS}

- Departamento de Ouvidoria Geral do SUS - no qual encontrase:

- Histórico da Ouvidoria Geral do SUS;

- Parcerias firmadas com outras instituições:

- Secretaria Especial de Políticas para as Mulheres

- Instituto Nacional do Câncer

- Agência Nacional de Vigilância Sanitária

- Serviços e Sistemas da Ouvidoria - mostra a composição do sistema de ouvidoria do SUS:

- OuvidorSUS - campo com acesso restrito;

- Portaria no. 1193/04 - disciplina o funcionamento do Departamento de Ouvidoria Geral do Sistema Único de Saúde. Uma das exigências desta Portaria que é a disponibilização aos cidadãos de formulário no site do Ministério da Saúde, para o recebimento de denúncias, reclamações, sugestões ou solicitação de informações. Desta maneira, a Ouvidoria SUS, amplia, assim, as formas de comunicação. Ihttp://portal.saude.gov.br/portal/saúde: acesso em novembro de 2006]

- Fale com o Ministério - canal onde é possível registrar uma reclamação ou denúncia e disponibiliza orientações para o correto preenchimento do formulário.

Formulário de Acesso com o Fale com o Ministério:

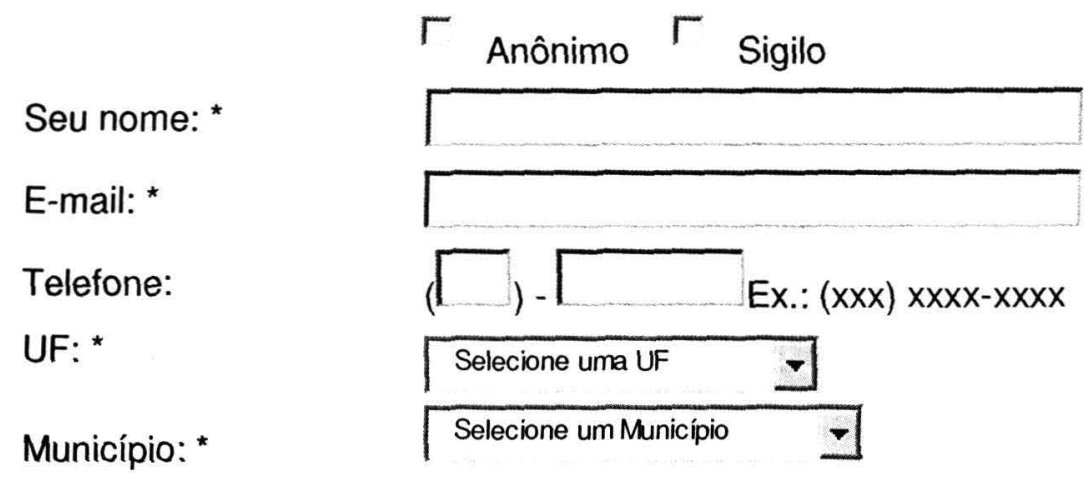


Endereço:

O que deseja? *

Selecione uma Opção _

Assunto: *

Selecione um Assunto

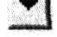

Assuntos Relacionados:

Selecione um Assunto Relacionado

Mensagem: *

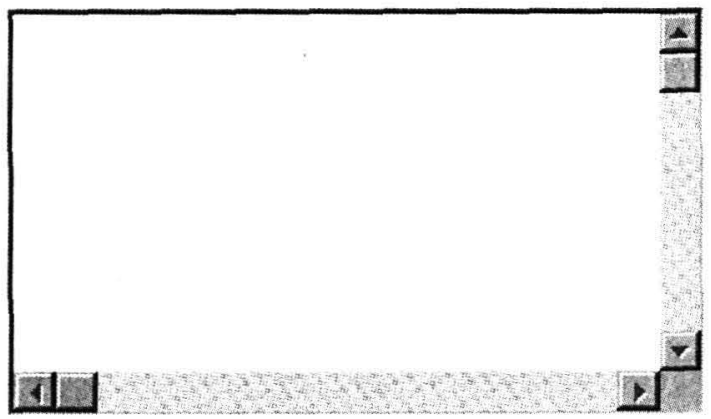

* Campos obrigatórios.

- Fórum Externo: Espaço reservado às discussões e questionamentos acerca do sistema Ouvidor Geral do SUS. Através deste canal, qualquer pessoa interessada no assunto poderá através de um fórum de discussão, debater o tema, fazer sugestões, tirar dúvidas, dentre outras possibilidades.

- Perguntas Freqüentes: A Ouvidoria do SUS trabalha também com o intuito de esclarecer as dúvidas dos cidadãos, tanto as relacionadas às doenças quanto às políticas de saúde. Oferece acesso às Perguntas Freqüentes feitas ao Ministério da Saúde, sobre Assistência Farmacêutica; Cartão Nacional de Saúde Cartão SUS; Denúncias e Reclamações; Doenças; Farmácia Popular; Medicamentos Fracionados; Planejamento Familiar; Programas do Ministério da Saúde; Publicações; Repasse Financeiro; Tabagismo; Vacinas.

Com relação ao tema Denúncias e Reclamações encontramos as seguintes repostas:

Como Proceder para sua Manifestação? 
A Secretaria Municipal de Saúde é a representação do Ministério da Saúde na sua cidade para fazer o tratamento das demandas dos seus munícipes. Deve-se procurar este órgão antes de efetuar seu registro na Ouvidoria Geral do SUS.

\section{Como Registrar sua Manifestação na Ouvidoria SUS?}

Para que o registro seja atendido é necessário preencher o cadastro com o nome, endereço, forma de contato, e também todos os dados para uma apuração mais completa possível.

\section{Pode-se Registrar uma Denúncia ou Reclamação em Anonimato?}

Os registros efetuados em anonimato quando necessitam de provas ou comprovação não são apurados, baseados no artigo 5 , inciso IV da Constituição Federal.

\section{Qual a Diferença entre Registro em Anônimo para o Sigilo?}

Algumas instituições apuram o registro que está em anônimo, caso haja necessidade de provas ou comprovação, a demanda não é apurada, baseada no artigo $5^{\circ}$. da Constituição Federal. Para o registro em sigilo o cadastro do cidadão não será revelado ao órgão que fará a apuração, mas caso haja necessidade de provas, a Ouvidoria Geral do SUS, entrará em contato com o cidadão que registrou a demanda para solicitar autorização de disponibilização de cadastro.

Quando Posso Levar uma Representação a Ouvidoria Geral do SUS?

Antes de fazer uma representação a Ouvidoria-Geral do SUS deve-se procurar a instituição que pertença ao Sistema Único de Saúde (Diretoria da Unidade de Saúde, Secretaria Municipal, Secretaria Estadual de Saúde ou Agência Reguladora), e utilize todos os procedimentos de representação que ela tiver incluindo um apelo ao responsável pela organização. Caso a instituição possua Ouvidoria dirija-se a ela. Entretanto, se houve tentativa sem sucesso de resolução do problema diretamente com a instituição, é importante que entrar em contato com a Ouvidoria-Geral do SUS. Deve-se estar atento e obter os nomes de todas as pessoas com quem teve contato; - Registrar as datas do seu contato com a Instituição e - guardar todos os papéis e cartas relacionadas com o seu caso. 
Existe um Modelo para Correspondência (carta ou fax)? Não. Deve-se escrever da forma como achar melhor, mas é fundamental que as informações sejam precisas e completas como nome, endereço completo com CEP, telefone com $D D D$, para a agilização do encaminhamento a ser dado à questão.

Alguns Exemplos de Casos que podem ser Intermediados Pela Ouvidoria Geral do SUS ou Pela Ouvidoria da Sua Cidade?

- Recusa à internação em Hospital do SUS; - Negativa em prestar informações sobre o atendimento em Posto de Saúde; - Recusa em fornecer cópias de documentos do prontuário do paciente; - Cobrança pelo atendimento feito pelo Sistema Único de Saúde, tanto do médico quanto do anestesista ou outro profissional de saúde; - Negativa em permitir acompanhantes para menores de 12 anos e maiores de 60 anos de idade; - Condições inadequadas de higiene e instalações sujeitas à fiscalização sanitária.

Com relação às informações, seria interessante um link que informasse ao cidadão sobre os seus direitos enquanto usuário do Sistema Único de Saúde, ou seja, que o remetesse à "Carta dos Direitos dos Usuários da Saúde, que baseia-se, nos seis princípios básicos da cidadania, conforme descrevemos de forma sucinta abaixo:

No primeiro princípio encontramos que, todo cidadão tem direito ao acesso ordenado e organizado ao sistema de saúde. Assim, fica garantido aos usuários a facilidade de acesso, aos postos de saúde, especialmente aos portadores de deficiência, gestantes e idosos.

O segundo e terceiro princípios do documento esclarecem ao cidadão sobre o direito a tratamento adequado para seu problema de saúde. Também faz referência à necessidade de um atendimento humanizado, acolhedor e livre de qualquer discriminação (preconceito de raça, cor idade ou orientação sexual, estado de saúde ou nível social).

O quarto princípio da carta garante que o atendimento prestado ao cidadão deve respeitar a sua pessoa, seus valores e seus direitos. Assegurando ao paciente, por exemplo, o conhecimento de seu prontuário médico, sempre que solicitado por ele.

Neste princípio em especial, encontramos no seu artigo XII, o seguinte: 
XII. Ter acesso aos mecanismos de escuta para apresentar sugestões, reclamações e denúncias aos gestores e às gerências das unidades prestadoras de serviços de saúde e as ouvidorias, sendo respeitada a privacidade, o sigilo e a confidencialidade.

O quinto princípio fala sobre as responsabilidades do cidadão para que ele tenha um tratamento adequado.

O sexto, e último princípio da carta garante que todos os princípios sejam cumpridos. Sendo necessário que todos os gestores da saúde, representantes das três esferas de governo (federal, estadual e municipal), se empenhem para que os direitos dos cidadãos sejam respeitados.

O papel da ouvidoria está intrinsecamente ligado à informação aos usuários do serviço público e/ou conveniado de saúde. Fazendo-se importante que o mesmo conheça seus direitos e deveres.

\section{Há Algum Custo para Fazer uma Representação?}

Não. O Ministério da Saúde financia todos os serviços da OuvidoriaGeral do SUS, cujo trabalho resulta, muitas vezes, numa correção rápida de problemas que, de outra forma, poderiam ter um custo muito elevado ou soluções demoradas.

\section{A Identificação é Obrigatória?}

Não, é opcional. Contudo, se você optar pelo anonimato, a Ouvidoria não poderá informá-lo acerca do resultado de sua representação. Caso queira identificar-se e manifestar o interesse de que sua identidade seja resguardada, a Ouvidoria assume o compromisso de mantê-la em sigilo.

A Identificação é Obrigatória no caso de Denúncias? Nos casos que envolvem apuração e investigação, não basta ligar ou enviar uma mensagem e fazer a denúncia. A Ouvidoria precisa de um relato completo do assunto, documentos comprobatórios, bem como tudo o que possa servir como subsídio para viabilizar a solução. Recomendamos que o cidadão oficialize a denúncia, por escrito, e com seus dados pessoais de identificação (a denúncia pode ser anônima, caso o cidadão não queira se identificar, enquadrando-se na situação anterior). 
Quanto Tempo Devo Esperar Para Obter Uma Resposta? Procuramos agir o mais rápido possível. Algumas questões poderão demandar um tempo maior para resposta, especialmente quando houver necessidade de encaminhamento para outras áreas, instituições ou esferas de governo. Entretanto, garantimos que a Ouvidoria acompanhará o caso até obter uma resposta para fornecer ao cidadão.

- Queremos saber o que Você tem a Dizer: Tópico designado às informações, sugestões, reclamações e denúncias;

- Informações úteis sobre o acesso a Ouvidoria;

- Veja como seu Estado está acessando a Ouvidoria

É possível através deste link acessar textos e estatísticas relativas a ouvidoria na saúde, nos diversos Estados brasileiros.

\subsection{Entrevista com Ouvidor da Secretaria do Estado da Saúde de São Paulo - SES/SP - "Ouvidor do Estado "SES/SP")}

A Ouvidoria na saúde, no Estado de São Paulo, traz uma contribuição histórica, colaborando com a instituição deste novo ator na área da saúde. $\mathrm{O}$ Ouvidor do Estado SES/SP, conta com uma experiência de quase 10 anos de ouvidoria na saúde, com amplo conhecido de saúde pública e também tendo exercido o papel de Secretária Executiva do Conselho Estadual de Saúde de São Paulo, de 1996 a 2003.

A criação da ouvidoria da SES/SP, respondia a uma demanda da $2^{\mathrm{a}}$. Conferência Estadual de Saúde, realizada em junho de 1996, que recomendou a regulamentação de diversos dispositivos do Código de Saúde do Estado de São Paulo.

$\mathrm{Na}$ SES/SP, entende-se que o ouvidor da saúde já esteja bem difundido e estabelecido nas diferentes instâncias de gestão dos sistemas de saúde, hospitais, institutos, centros de referências, ambulatórios de especialidades e unidades básicas de saúde, mantendo, sempre, uma relação cordial com as ouvidorias e fundações, autarquias e universidades. 
Atualmente, o Estado de São Paulo, conta no seu Sistema de Ouvidoria na Saúde, em torno de 150 pessoas desempenhando a função de ouvidoria.

\subsubsection{A Ouvidoria do Estado da Saúde de São Paulo - SES/SP - "Ouvidoria do Estado SES/SP"}

São Paulo é o Estado com a maior população do Brasil, mais de 40 milhões de habitantes distribuídos em 645 municípios, e a terceira unidade administrativa mais populosa da América do Sul. Abriga o maior parque industrial e a maior produção econômica - mais de $31 \%$ do PIB do país. Detém o maior registro de imigrantes, quase 3 milhões de 70 nacionalidades diferentes. [http://www.saopaulo.sp.gov.br/saopaulo/ - acesso em 27 de maio de 2007]

A estrutura da SES/SP está definida, conforme organograma abaixo:

\section{ORGANOGRAMA DA SECRETARIA DO ESTADO \\ DA SAÚdE DE SÃO PAULO - "SES/SP"}

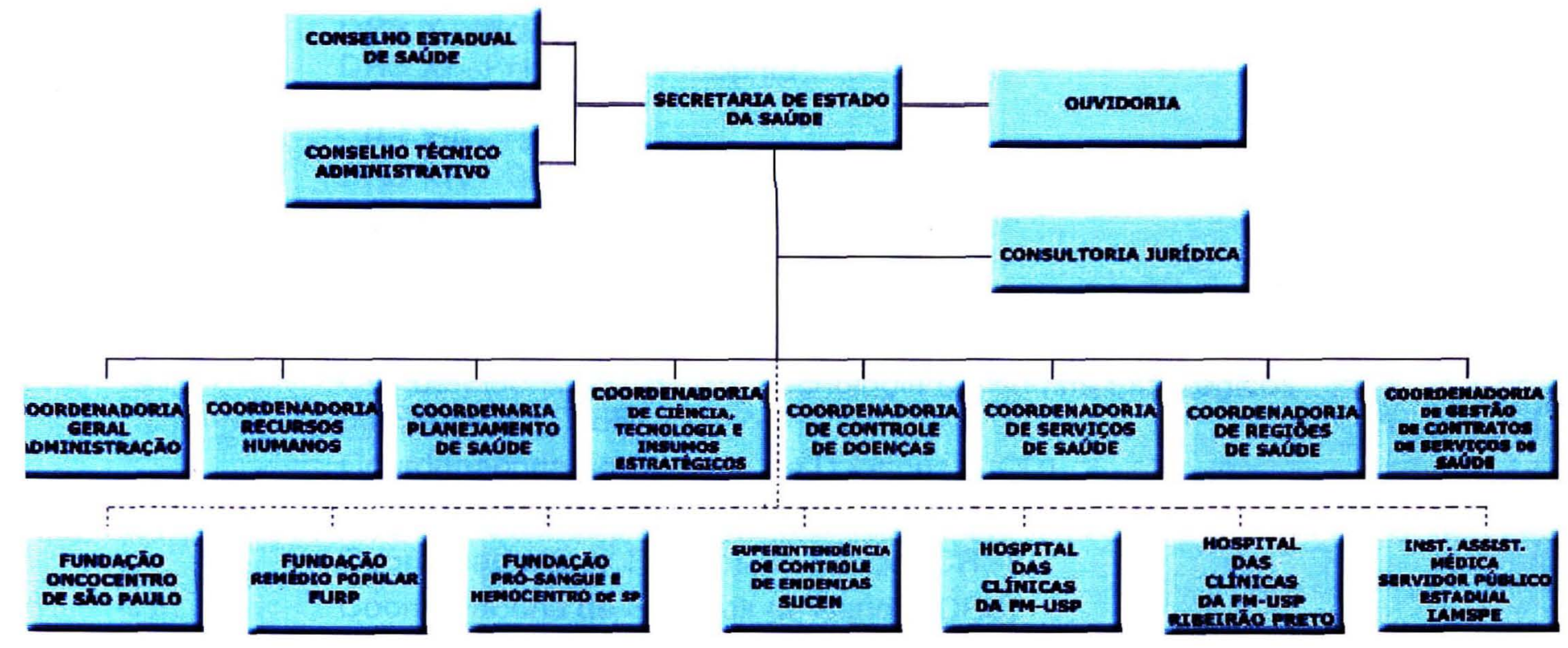

Fonte:

[http://portal.saude.sp.gov.br/homepage.mmp?home=402881b40e9f7c76010ea $499333 \mathrm{c} 0037$

- link: estrutura - organograma - último acesso em agosto de 2008]

Através do organograma, verifica-se, que a Ouvidoria da SES/SP está diretamente ligada ao Secretário do Estado da Saúde. 
No site da Secretaria do Estado da Saúde de São Paulo, encontramos, diversas informações sobre a saúde, entre elas, um link direto com a ouvidoria daquela Secretaria, bem como, um caminho de busca á todas as ouvidorias que existem naquele Estado, conforme mostramos a seguir:

Abaixo está disponível um sistema de busca de ouvidores da SES/SP Escolha a Instituição da Secretaria que deseja pesquisar: Áreas Disponíveis

Nas áreas disponíveis, é possível acessar:

\section{Regionais de Saúde}

DRS I - Grande São Paulo

DRS II - Araçatuba

DRS III - Araraquara

DRS IV - Baixada Santista

DRS V - Barretos

DRS VI - Bauru

DRS VII - Campinas

DRS VIII - Franca

DRS IX - Marília

DRS $X$ - Piracicaba

DRS XI - Presidente Prudente

DRS XII - Registro

DRS XIII - Ribeirão Preto

DRS XIV - São João da Boa Vista

DRS XV - São José do Rio Preto

DRS XVI - Sorocaba

DRS XVII - Taubaté

\section{Coordenadorias}

Coordenadoria de Ciência, Tecnologia e Insumos Estratégicos de Saúde (CCTIES)

Coordenadoria de Controle de Doenças (CCD)

Coordenadoria de Planejamento de Saúde (CPS)

Coordenadoria de Regiões de Saúde (CRS)

Coordenadoria de Serviços de Saúde (CSS)

Coordenadoria Geral de Administração (CGA)

Coordenadoria de Recursos Humanos (CRH)

Coordenadoria de Gestão de Contratos de Serviços de Saúde

\section{Unidades de Saúde}

Ambulatórios de especialidades 
Centros de Atenção Integral à Saúde da Mulher

Centro de Reabilitação

Centro de Referência de Álcool, Tabaco e Outras Drogas

Centro de Referência do Idoso

Centros de Saúde

Complexos Hospitalares

Conjuntos Hospitalares

Divisões de Medicina e Reabilitação

Hospitais Estaduais e Gerais

Núcleos de Gestão Assistencial

Unicamp

\section{Outros Órgãos}

Centro de Vigilância Sanitária

Centro de Referência e Treinamento de AIDS

Fundação para o Remédio Popular - FURP

Fundação Pró-Sangue - Hemocentro São Paulo

Fundação Oncocentro de São Paulo - FOSP

Instituto Adolfo Lutz

Instituto Dante Pazzanese de Cardiologia

Instituto de Assistência Médica do Servidor Público Estadual IAMSPE

Instituto Pasteur

Superintendência de Controle de Endemias - SUCEN

Através do item "Áreas Disponiveis" pode-se contatar as ouvidorias das: coordenadorias de saúde, das diretorias regionais de saúde, unidades de saúde e outros órgãos.

Ao acessar qualquer uma das informações, localiza-se, o endereço da ouvidoria, nome do ouvidor, forma de acesso online e também via fone, obtendo-se, a mesma informação, com relação a ouvidoria geral da saúde do Estado.

Apesar do site trazer alguns avanços, como a localização das ouvidorias nas diversas instâncias de saúde do Estado, não informa, ao 
cidadão, que aciona a página, para que serve este canal. Sendo, assim, interessante, aproveitar mais deste espaço, publicizando a que se destina esta ouvidoria.

\subsection{Entrevista com Ouvidor da Saúde - Secretaria} Municipal da Saúde - "Ouvidor M-1"

O ouvidor desta Secretaria da Saúde possui uma importante experiência na área. Seu primeiro contato com a ouvidoria, foi em final de 1999, quando assumiu a ouvidoria de um grande hospital público da cidade de São Paulo, ficando até 2003, quando assumiu a ouvidoria da Secretaria Municipal de um Município do Estado de São Paulo.

\subsubsection{A Ouvidoria da Secretaria Municipal da Saúde -}

\section{"Ouvidoria M-1"}

A ouvidoria M-1, encontra-se em um município de São Paulo, cuja população, perfaz cerca de 500 mil habitantes, conforme dados do IBGE. [http://www.ibge.gov.br/home/-acesso em Abril de 2007]

Esta Secretaria Municipal de Saúde é composta por: 40 unidades básicas de saúde, 6 unidades de pronto-atendimento, 2 hospitais municipais e 17 unidades de especialidades de saúde.

Com relação ao site da Ouvidoria $\mathrm{M}-1$, acessou-se, primeiramente, o site da Secretaria Municipal da Saúde, onde foi possível encontrar informações referentes aos serviços oferecidos e sobre saúde em geral, bme como, um link direto para acesso da ouvidoria.

Detectou-se, também, na primeira página do site: telefones, endereços e outras formas de contato e, nesta mesma página, encontramos um caminho para entrar no campo da Ouvidoria.

Constatou-se, algumas informações importantes, no acesso ao site:

A quem se destina a ouvidoria: a todos os munícipes do SUS que buscam informações, queiram dar sugestões ou fazer queixas sobre o serviço de saúde daquele município.

Objetivo da Ouvidoria da Saúde: qualificar constantemente o atendimento prestado pela Secretaria Municipal da Saúde, acatando e 
respondendo às solicitações de informações, denúncias e elogios dos munícipes.

Formas de Contato com a Ouvidoria: pessoalmente ou por carta, citando o endereço e horário de atendimento, telefones para contato e e-mail ou pessoalmente.

Apesar do formato simples, informa objetiva e esclarecidamente o cidadão, abrindo assim, um canal de comunicação e participação.

\subsection{Entrevista com Ouvidor da Saúde - Secretaria Municipal da Saúde - "Ouvidor M-2"}

A escolha deste Ouvidor M-2 deveu-se a esta ouvidoria situar-se num grande Município do Estado de São Paulo, considerado um desafio para 0 estabelecimento de uma ouvidoria.

O ouvidor M-2, também possui experiência anterior em ouvidoria na saúde, tendo sido ouvidor de um hospital público, neste mesmo município. Em meados de 2004 foi convidado a assumir a ouvidoria desta Secretaria Municipal de Saúde.

\subsubsection{A Ouvidoria da Secretaria Municipal de Saúde - "Ouvidoria - M-2"}

A Secretaria Municipal da Saúde onde se insere a Ouvidoria M-2, localiza-se numa grande Cidade do Estado de São Paulo, com uma população de cerca de 10 milhões de habitantes, conforme dados do IBGE Instituto Brasileiro de Geografia e Estatística. [http://www.ibge.gov.br/home/ acesso em 29/04/2007]

Basicamente integram a estrutura do SUS desta Secretaria Municipal de Saúde: autarquias hospitalares e coordenadorias de saúde das subprefeituras, sendo que cada coordenadoria de saúde, é composta de supervisões de saúde, que variam em número, dependendo da região da coordenadoria.

O site da Secretaria Municipal de Saúde contempla várias informações importantes aos cidadãos. Encontra-se dificuldade no acesso das informações da ouvidoria. Após, acessar vários links, consegue-se localizar, 
juntamente com a organização da Secretaria, link, no qual localiza-se o nome do Secretario da Saúde, assessores e por último o nome do ouvidor, telefones para contato e um e-mail.

A localização da Ouvidoria, dentro de um site, poderá contribuir para a estimulação e/ou desestimulação do Cidadão em estar acessando a mesma.

A ouvidoria desta Secretaria Municipal de Saúde, conforme entrevista com o Ouvidor M-2, conta com 6 ramais, que funcionam das 7h00 até às 19 h00, recebendo uma média de 16.000 ligações mensais. Das quais aproximadamente, entre 600/700 são queixas/denúncias e solicitações. Recebe-se, também, uma média de 350 expedientes por mês, provenientes da Ouvidoria Geral, existente neste Município.

Com um fluxo grande como o apresentado pelo Ouvidor M-2, faz-se importante configurar a que se destina este espaço dentro da administração pública de saúde, bem como, discutir com o gestor central, quais as formas de aproveitamento administrativo-gerencial, frente a esta demanda.

\subsection{Análise dos Dados}

Para fins de análise, sistematização e interpretação dos dados, utilizou-se a transcrição do material gravado, através das entrevistas e os dados selecionados nos documentos, segundo a técnica de análise proposta por BARDIN (1983), que consiste na sistematização do material recolhido a partir de temas básicos de interesse para o estudo.

O material coletado foi lido e relido, na tentativa de detectar os temas e temáticas mais freqüentes. Esse procedimento é essencialmente indutivo e culminou na construção de categorias ou tipologias (LUDKE e ANDRÉ, 1986). Alguns procedimentos como a classificação dos conceitos, a codificação dos mesmos, a categorização de acordo com os temas, entre outros serão indispensáveis no uso deste método.

As abordagens qualitativas da pesquisa visaram, sobretudo a compreensão. Procurando, descobrir temas partindo de seus significados para que pudéssemos compreender e entender o problema em estudo. (WESTPHAL, 1992). 
Utilizou-se as seguintes categorias e sub-categorias de análise:

- Ouvidoria na Administração Pública nos Três Níveis de Gestão

- A Importância do Comprometimento do Gestor com a Instituição da Ouvidoria

- Participação do Usuário na Administração Pública de Saúde

- Papel do Ouvidor no Setor Público de Saúde:

- Ouvidoria X Gestão

- Geração de Indicadores

- Publicização do trabalho da Ouvidoria 


\section{ASPECTOS ÉTICOS DA PESQUISA}

O projeto de pesquisa foi avaliado pelos Comitês de Ética das devidas instituições. Todos os sujeitos de pesquisa incluindo o então Ouvidor Geral do SUS, Ouvidor Estadual SES/SP e, das duas Secretarias Municipais, M-1 e M-2 foram devidamente esclarecidos, através de um Termo de Consentimento Livre e Esclarecido, sobre os objetivos da pesquisa, forma de participação, voluntariedade, podendo optar pelo caráter pessoal ou impessoal das informações, e desistir de participar em qualquer momento da pesquisa. Tomou-se os devidos cuidados para garantia do anonimato das informações, bem como, formas de contato com o pesquisador responsável.

Pretende-se divulgar o resultado do estudo, para os devidos ouvidores, bem como, através da publicação de artigos científicos, participação em congressos e disseminação e discussões sobre o tema. 


\section{ANÁLISE E DISCUSSÃO DAS ENTREVISTAS}

Teve-se como intuito estabelecer conexões entre teorias já fundamentadas e o papel da ouvidoria. Durante a pesquisa sobre ouvidoria na área da saúde, encontrou-se dificuldade quanto ao embasamento, definições conceituais e relatos de experiências Neste sentido, não se objetivou elaborar um conceito fechado para a função, mesmo porque, em cada administração pública, voltada para a saúde, poderia surgir um conceito diferente que viesse ao encontro, da ouvidoria instituída naquela instituição. Portanto, propõe-se descrever e analisar a experiência das ouvidorias na saúde nos três níveis de gestão: Municipal, Estadual e Federal.

Considera-se, o canal da ouvidoria de grande importância em qualquer contexto no qual ele se insere. Um dos grandes questionamentos, que podese enfatizar, principalmente na área da saúde publica, é para que e quem serve este canal?

Contudo, verifica-se, que no campo da saúde, cuja experiência da ouvidoria é muito complexo caracterizar este novo instrumento de gestão e participação popular, pois este ainda esta em construção.

O Ouvidor Geral do SUS, em seu relado, considera que:

"O que a gente tem insistido muito e parece que é uma discussão que está sendo construída, aliás, a própria ouvidoria está sendo construída. Ouvidoria em saúde mais ainda, pela característica dela". (Ouvidor Geral do SUS)

\subsection{Ouvidoria na Administração Pública de Saúde nos}

\section{Três Níveis de Gestão}

A Ouvidoria Geral do SUS situa-se, conforme descrito no capítulo anterior, na Secretaria de Gestão Estratégica e Participativa, órgão ligado ao Ministério da Saúde, conforme anteriormente descrito.

A Ouvidoria do Estado situa-se, juntamente ao Gabinete da Secretaria do Estado da Saúde, conforme relata o Ouvidor do Estado:

A ouvidoria está diretamente ligada ao Gabinete, então, os problemas que a gente tem e não se consegue organizar diretamente, ou que necessite de outro, são discutidos na Chefia de Gabinete. Os relatórios que são semestrais são repassados, para o Secretário, que é quem avalia tudo que foi trazido, para encaminhar pro Governador. $E$, internamente, isto é discutido, na reunião de coordenadores $e$, 
todos os diretores das Direções Regionais de Saúde. (Ouvidor do Estado SES/SP)

No contexto do Município da Ouvidoria M-1, existe somente esta ouvidoria central no setor saúde, a qual acolhe todas as demandas.

Sobre a Ouvidoria M-2, tem-se o seguinte relato:

“..., a ouvidoria possui estrutura descentralizada, estando presente em cada coordenadoria de saúde -, o que somente contribui para o fortalecimento da gestão participativa, facilitando e agilizando as ações na saúde, com a eficácia e eficiência necessárias. Como exemplo dessa postura da Administração Municipal, veja-se o número sempre crescente dos equipamentos de saúde, que visam cobrir o atendimento em saúde de parcela cada vez maior da população. As ações são incessantes, e a população sempre atendida em suas manifestações verbais e nas demandas de saúde".(Ouvidor M-2)

Com relação ao acima exposto, o Ouvidor $M-2$, esclarece que na organização do sistema de saúde deste Município, as coordenadorias de saúde possuem pessoas-chaves, que além de desenvolverem suas funções básicas atendem as solicitações da ouvidoria, como uma forma de centralizar as demandas por região.

Ainda, com relação à caracterização destas ouvidorias, não foi possível estabelecer qual a política de ação das mesmas. Considera-se, esta informação relevante, pois através dela, é possível definir qual compromisso proposto pelas mesmas.

Considera-se que grande parte da população saiba minimamente o que é uma ouvidoria, entretanto, é extremamente importante que informações adicionais sejam publicizadas constantemente, para que as pessoas possam se instrumentalizar e utilizar este canal de forma pedagógica e correta, compreendendo seu campo de atuação e seus limites.

A Ouvidoria do Estado de São Paulo possui um mapeamento detalhado, encontrado, através do acesso ao site, que informa em quais órgãos e/ou equipamentos de saúde possuem ouvidoria, bem como, estabelece as formas de contato.

Conforme relata o Ouvidor do Estado SES/SP;

"Na Secretaria de Estado da Saúde, acredito que o papel do Ouvidor da saúde já esteja bem difundido e estabelecido nas diferentes instâncias de gestão do sistema de saúde, nos hospitais, institutos, centros de referência, ambulatórios de especialidades e unidades 
básicas de saúde. Vimos mantendo boa relação com as ouvidorias das fundações, autarquias e universidades e no caso específico da Cidade também com a ouvidorias Geral do Município. Ao todo devemos ter nos Sistema de Ouvidoria da Saúde em torno de 150 pessoas desempenhando uma nova função de ouvidoria. (Ouvidor do Estado SES/SP)".

Ressalta-se, a esta questão, que as ouvidorias do Ministério da Saúde e Municipais, deveriam mapear, definir e destacar em quais órgãos e/ou instituições possuem sua própria ouvidoria, tais como: autarquias, fundações, se houver, instituições de saúde - hospitais, ambulatórios, Unidades Básicas de Saúde, PSF --. Mapear estas instituições para unificar ações o que muito contribuiria, para que houvesse uma descentralização da Ouvidoria na Saúde, abrir mais espaço para atuação do ouvidor, como por exemplo: fomentar a discussão do papel da ouvidoria, verificar a problemática de cada região e reportar ao gestor local, contribuir para a discussão de novas políticas e programas de saúde nas diferentes regiões, fortalecer assim, a sua atuação e definir melhor o papel da ouvidoria na área da saúde colaborando, dessa forma com a gestão.

Para ARAÚJO (2002), a credibilidade no poder público só pode ser resgatada por meio da tomada de políticas sérias e de idoneidade na gestão de verbas. Para a Autora, a ouvidoria foi criada para colaborar no resgate dessa credibilidade. Além disso, a ouvidoria se propõe a se tornar um instrumento eficaz na valorização do exercício de cidadania, ampliando os canais de comunicação direta entre a administração pública de saúde e a população, expandindo a capacidade do cidadão de participar na fiscalização e avaliação das ações de saúde e subsidiando o aprimoramento da organização e funcionamento dos serviços de saúde, tendo por base o humanismo e os princípios éticos.

\subsection{A Importância do Comprometimento dos Gestores com a Instituição da Ouvidoria}

Por outro lado, verifica-se, que a ação da ouvidoria fica prejudicada, se não houver interesse e compromisso por parte do Gestor Público, em qualquer nível de atuação. 
Conforme relata o Ouvidor Geral do SUS:

"A partir do momento que o Governo tem uma oposição na maioria dos Estados, e os Estados não estão nem aí, mesmo os Conselhos que tem que ter autonomia no processo político, eles têm que se movimentar, têm que participar tem que fazer conselhos gestor em todas as unidades de saúde. Este processo depende do gestor máximo, que são os Prefeitos e Governadores. Mas, se Você não tem o governo do seu lado, o prefeito do seu lado, o governador do seu lado. É difícil! (Ouvidor Geral do SUS)".

Tudo indica que a implantação de ouvidorias institucionais esteja quase sempre relacionada a interesses políticos, no entanto, parece contraditório pensar que esses interesses não se direcionem em favor do cidadão.

Por outro lado, a alternância de forças antagônicas no poder é normal na democracia. A cada eleição, mudam os titulares dos cargos executivos, freqüentemente substituídos por adversários políticos, ideologicamente divergentes. Essa alternância com freqüência ocasiona a descontinuidade de projetos em andamento, determinando a mudança de objetivos políticos, sociais e administrativos. As ouvidorias podem ser diretamente afetadas por essas mudanças, no cenário político, seja porque determinada administração resolve desestimular a ação das ouvidorias esvaziando suas funções, seja porque a ouvidoria poderá ser ocupada por pessoa de confiança do novo titular da pasta. Exercendo cargo de confiança, o ouvidor que permanecer no cargo terá de adequar sua atuação às diretrizes da nova administração. (CENTURIÃO, 2003)

O Ouvidor Geral do SUS considera que este é um espaço que pode ser manipulado para os fins que interessa a cada gestor, do mesmo modo que ocorre com os conselhos de saúde que são instituídos apenas por uma exigência de legal.

"E aí você tem o perigo de perder o poder. É a mesma coisa por exemplo que é a criação do Conselho Municipal, Estadual e Federal, conforme o SUS. Mas, na maioria das cidades, os Conselhos ou não funcionam ou são manipulados pelo gestor... o gestor somente quer verba para poder trabalhar e poder reivindicar. Então, nós estamos tentando fazer um grande trabalho, que ainda está em aberto. Mas, como sensibilizar o gestor que não tem compromisso?" (Ouvidor Geral do SUS) 
LYRA (1995), afirma que, para vencer as dificuldades inerentes à um processo tão inovador, é preciso que os dirigentes e funcionários da Administração sejam sensibilizados para a importância do trabalho da ouvidoria.

Estabelecer criteriosamente o papel da Ouvidoria Geral do SUS, definindo missão, valores, diretrizes e acompanhar o processo de construção e atuação das ouvidorias com os gestores, respeitando-se sempre as peculiaridades de cada nível de gestão, podería ser uma forma de sensibilizar e incentivar a sua implementação. Como a Ouvidoria SUS, é muito incipiente, provavelmente ainda não foi possível definir claramente seu papel, dificultando aos gestores a compreensão do real significado deste importante instrumento de gestão, e adotando-a por vezes somente enquanto imposição legal.

É importante ressaltar que a Ouvidoria SUS trabalha por meio do Pacto de Gestão. Isto significa uma mudança do modelo verticalizado, através do qual o Ministério da Saúde repassava aos Estados e Municípios as políticas, ações e programas, que seriam implantados, pelo novo modelo de adesão solidária aos Termos de Compromisso de Gestão no qual cada Estado e Município se reorganiza e se compromete, conforme suas responsabilidades. Dessa forma, os gestores passam a ter maior flexibilidade na definição de parâmetros e prioridades que irão orientar a programação. (MS, PACTOS pela Saúde, Volume 1, 2006)

Dentre as ações que devem ser desenvolvidas para fortalecer 0 processo de participação social deste pacto destaca-se, 0 apoio a implantação e implementação de ouvidorias nos municípios e estados, com vistas ao fortalecimento da gestão estratégica. (MS, PACTOS pela Saúde, Volume 1, 2006) (GRIFOS NOSSOS)

Este momento na saúde relacionado às proposições do Pacto de Gestão e a necessidade de, pactuação constante aparece no relato abaixo:

"Não adianta, colocar um decreto ou uma lei e dizer, olha, a partir de hoje, Vocês vão fazer isto! Daí ele responde de lá: mas eu tenho condições de fazer isto? Então tem que ir na limitação que é. Tudo tem que ser conversado, discutido. (Ouvidor Geral do SUS) 
Esta é a ocasião ideal para difundir a importância desse valioso instrumento de gestão, com a perspectiva de atingir o maior número de gestores.

Os seguintes relatos demonstram que alguns gestores parecem entender o papel da ouvidoria e respaldam a ação da mesma:

"No caso da saúde, as discussões elas são, com todos os gestores, seja um gestor local da unidade, seja um gestor da coordenadoria, seja o gabinete do Secretário. Há um respaldo com relação a ouvidoria".(Ouvidor do Estado SES/SP)

O Ouvidor M-2 corrobora ao afirmar que o Gestor Público compreende e apóia o trabalho da ouvidoria, conforme verificamos:

"A ouvidoria a partir da minha nomeação, responde diretamente ao Gabinete. O chefe da ouvidora é o chefe de gabinete. A ouvidoria é respeitada, considerada e aceita. Os problemas que a ouvidora leva ao Gabinete são encarados com muita seriedade. (Ouvidor M-2)

Afirma BELLISOMI (2003) que outro aspecto importante, refere-se à suscetibilidade da ouvidoria, enquanto controle externo, pela burocracia. A questão, segundo o autor é relevante porque a possibilidade de sucesso na implantação de um controle diminui quando ele é rejeitado pelos burocratas, ao mesmo tempo, em que os custos da implantação também podem aumentar devido às inúmeras resistências que suscitam em alguns funcionários públicos.

Concorda-se, que a ouvidoria somente se efetivará enquanto canal participativo, isto é, quando seu objetivo for além da satisfação e interesse individual do usuário.

O Ouvidor Geral do SUS lança o desafio com relação a esta questão, conforme abaixo:

"O processo está em aberto. Para nós ainda há o desafio da ouvidoria ser pública. Na realidade, a ouvidoria privada tem sentido: qualidade $e$ satisfação do usuário. Vivemos hoje numa sociedade de espetáculos, na qual a pessoa não é cidadão mas sim consumidora! Os valores estão pautados se ela é consumidora ou não é consumidora! Não importa se ela participar, se ela é cidadã! Então esta questão do consumidor está muito arraigada à concepção da ouvidoria privada." (Ouvidor Geral do SUS) 
Contudo, apesar da ouvidoria no setor privado ter seu papel melhor definido, no setor público ainda é necessário fomentar discussões acerca de seu papel, de sua importância e apropriar-se deste canal de comunicação, que pode contribuir para a transparência das ações, como um instrumento de diagnóstico e planejamento buscando a melhoria da qualidade do serviço público.

\subsection{Participação do Usuário na Administração Pública em Saúde}

Com relação à questão da cidadania e participação social, conforme discutido na introdução deste trabalho, o Ouvidor $M-1$, traz uma questão interessante. Percebe-se pelo relato uma mudança de postura, tanto na atitude, quanto na expectativa do usuário em relação a resposta à sua demanda.

"Uma coisa que me chamou a atenção, com relação ao retorno do usuário. Dar retorno ao usuário, ainda que a demanda dele tivesse gerado uma mudança significativa, ou se não houvesse gerado um grande conflito, responder um pouco ao munícipe. Na nossa estatística, $46 \%$ deles, na época não se interessavam pela resposta. Este é um dado muito interessante. Era um dado assustador. A gente só percebeu quando fez as estatísticas e apareceu. Eu sempre ofereço a possibilidade da resposta por telefone, ou pessoalmente e, na época a grande maioria dizia assim: "não precisa encaminhar, não me interessa, não quero nem ouvir". Era considerado, como não recebendo a resposta daquilo que ele disparou. Outra coisa que me chamava a atenção, também, o fato das pessoas, logo de início quando chegavam, se desculpavam por estar ali, que era algo muito associado à questão da cidadania. Nós podemos exercer a nossa cidadania, podemos ir atrás dos nossos direitos, Você tem que pedir descuipas por isto, como se fosse uma coisa inadequada.

A fala abaixo demonstra uma apropriação deste canal enquanto direito de cidadania.

"...interessante, que na experiência atual, também, raríssimas vezes, eu vi o Munícipe chegar aqui e pedir desculpas por estar aqui, ele vem sabendo o que quer, e alguns querem a resposta e porque veio aqui, ele vai ter que ser passado na frente, e que isto daqui não serve pra nada, mas raríssimas ocasiões. Até o momento, eu não tenho nenhum retorno, nenhuma demanda gerada que tenha se negado a saber o que aconteceu, com a demanda que ele fez. Muitas vezes até ironiza: "Isto não acabou em pizza não?" Alguma coisa assim. A maioria quer saber. Eu acho que tem uma mudança significativa, por ser uma população distinta, outro lugar. Eu acho que são questões 
importantes que a gente percebe na ouvidoria, que talvez desse uma outra tese. (Ouvidor M-1)

Com relação a esta questão, PONTES (2000), afirma que cerca de $90 \%$ dos usuários que procuram a ouvidoria não acreditam efetivamente na solução, encaminhamento justo, ou mesmo, eficaz do problema demandado. A autora comenta que o espanto é ainda maior quando se verifica que qualquer cidadão pode ser atendido pela ouvidoria, sem privilégios, nem discriminação.

Frente ao recente movimento de instituição de ouvidorias, como um importante canal de participação que auxilia o usuário no exercício da sua cidadania, é imprescindível municiar o indivíduo de informações, estar sempre atento às suas demandas, dar feedback, seja positivo ou negativo, esclarecê-lo sobre seus direitos e deveres, como assegura o conceito de cidadania, ou seja, "empoderá-lo" enquanto cidadão promovendo também sua saúde social.

Os direitos do usuário nem sempre são respeitados e reconhecidos, muitas vezes, por puro desconhecimento do profissional da rede pública de saúde que da mesma forma necessita de informações, esclarecimentos e reciclagem constante.

"Quanto à reclamação, por exemplo, o cidadão, reclamou aqui, que ele solicitou cópia do prontuário dele e foi negado. "Não precisa fazer documento..." Não precisa nada! Ele solicita, ele tem direito. Ele tem acesso ao prontuário dele, está na lei. A Lei dos Direitos dos Usuários da Saúde" (Ouvidor M-2)

Para BAVA (1995), o exercício da cidadania é a construção de direitos sociais e políticos é o que chamamos de democracia. Se não houver esta noção de democracia individual e coletiva não se concretiza a cidadania. Ainda, para este autor, se não houver a criação de espaços públicos, os interesses que estão em jogo não se explicitam. Portanto, é preciso reconhecer e legitimar estes espaços públicos para que haja a oportunidade de se confrontar os interesses conflitantes.

É recorrente na fala do Ouvidor Geral do SUS a indefinição do papel da ouvidoria naquele espaço, o que dificulta sobremaneira a sua estruturação 
e atuação e gera confusão com outros canais de participação como, por exemplo, o controle social.

"Temos outra dificuldade muito grande que é saber onde se situa a ouvidoria. Se ela se situa no controle social ou na gestão. É uma discussão! Eu acho que a ouvidoria na saúde no SUS tem que estar localizada na gestão. Porque é a partir da gestão que Você pode sensibilizá-la. Se Você colocar no controle, Você perde o processo. $O$ controle vai confundir a ouvidoria com o controle. Não vai participar, vai ficar só reivindicatório! Na gestão, vai depender do gestor. Se o gestor é um gestor democrático, aí há a possibilidade dela se capitalizar, transformando o controle social em participação social. $O$ que eu quero é isto!" (Ouvidor Geral do SUS)

Reflete-se, ainda, se a ouvidoria é um canal de controle social ou um instrumento de gestão. Entende-se que a ouvidoria, através das demandas levantadas, organiza elementos capazes de aperfeiçoar processos. Não age enquanto um canal decisório, de definições de políticas, como acontece com os Conselhos de Saúde, mas sim, como um canal modificador de processos, retro-alimentando o sistema, buscando um melhor aprimoramento e qualidade do serviço.

PEREIRA (2000) discute o papel dos Conselhos de Saúde e da ouvidoria.

“ ... a ouvidoria não tem como pressuposto a organização prévia de usuários e a escolha de representantes que expressem suas discordâncias ou suas proposições, não existindo neste caso, a possibilidade de participação, no sentido de tomar parte do processo de decisão política, no entanto, eles podem vir a contemplar os setores mais frágeis da população, que sequer dispõem dos canais organizados de expressão política." (p.26)

Pode-se dizer que a forma de participação do usuário na ouvidoria se dá de forma direta, sem intermediários, diferentemente da atuação dos Conselhos de Saúde, que exige uma organização e representação. De todo modo, essa participação direta que a ouvidoria proporciona pode ser considerada radical na suas possibilidades de atingir até as camadas menos privilegiadas da população, as que não tem acesso à organização, como, por exemplo, o lumpenzinato.

A existência dos conselhos, de maneira alguma pretende inibir que o cidadão se organize de forma autônoma e busque formas próprias de reivindicações. Muito pelo contrário, os conselhos poderão atuar como rede de apoio à ação da ouvidoria. 
Para SERAPIONI, ROMANI (2006), a participação implica, necessariamente, a capacidade de influir, direta ou indiretamente, junto a um processo público decisório.

Este estudo não pretende dar conta de todas essas questões que foram levantadas, por isso, buscou-se compreender e focar a ação da ouvidoria dentro da administração pública, visando sempre uma maior sensibilização do gestor, em busca da participação social e respeito ao usuário.

\subsection{Papel da Ouvidoria no Setor Público de Saúde}

Os dados levantados por meio das entrevistas, mostraram a existência de diferentes concepções sobre o papel da ouvidoria na saúde nos três níveis de gestão. Apesar da riqueza dos depoimentos ainda se faz necessário refletir um pouco mais sobre o tema, bem como seria importante o desenvolvimento de diretrizes norteadoras para as ações da ouvidoria na saúde.

Segundo BELLISONI (2003), OLIVEIRA (2005) o ouvidor atua na defesa do cidadão contra a má administração, buscando soluções justas e razoáveis a partir de reclamações individuais ou coletivas. O ombudsman é uma instituição que atua no interesse público.

Para PINTO (1998) de um modo geral, o papel do ombudsman, na administração pública é de harmonizar as soluções burocráticas que não levem em consideração razões individuais das pessoas atingidas pelo ato administrativo, corrigindo inclusive estes atos. Caracteriza-se pelo informalismo na investigação e flexibilidade na atuação. (p.55) (GRIFOS NOSSOS)

O relato do Ouvidor Geral do SUS mostra que a discussão da ouvidoria é política. É um canal de articulação entre o cidadão, o gestor e os trabalhadores da saúde:

"Abrimos uma discussão política, primeiro por uma concepção doutrinária e programática do que é a ouvidoria e, sobretudo o que é uma ouvidoria do sistema de saúde, que para nós é uma ferramenta, um canal de articulação em três "entes". Quais entes? usuário e o cidadão, gestor democrático e gestor participativo e trabalhador na área da saúde, que é a junção de todo este processo. (Ouvidor Geral do SUS ) 
Já, a compreensão de Ouvidoria pelo Ouvidor do Estado SES/SP é entendida como instrumento de garantia de direitos dos cidadãos, acesso da população para queixas, reclamações e denúncias de violações de seus direitos, enquanto usuários dos serviços de saúde públicos ou privados, bem como, a possibilidade de melhoria da qualidade do serviço.

"A Ouvidoria na saúde é um canal de acesso à população, para queixas, reclamacões e denúncias de violacões de seus direitos enquanto usuários do SUS, sendo instrumento voltado para a garantia da melhoria da qualidade, do funcionamento e da organização do SUS... Qualquer cidadão brasileiro, ou não, pode apresentar suas solicitações, queixas ou sugestões, referentes a atendimento em hospitais, postos de saúde, ambulatórios, em órgãos públicos ou conveniados com o SUS".(Ouvidor Estado SES/SP) (GRIFOS NOSSOS)

Complementarmente ao acima exposto, o Ouvidor do Estado SES/SP afirma que a ouvidoria deverá não deverá atuar no papel de gestor, executor nem ser utilizado para sancionar, coagir ou penalizar. Neste sentido, entendese que sua atuação deverá permear todos os envolvidos no processo de forma mediadora e justa.

"A Ouvidoria do SUS, como instrumento de garantia dos direitos dos cidadão, enquanto usuários dos serviços de saúde públicos ou privados, no Sistema de Saúde - SUS-SP. Não se deve confundir o papel da ouvidoria com instâncias administrativas possuidoras de poder para resolucão de problemas técnicos administrativos, nem com órgãos sancionadores, coatores ou penalizadores." (Ouvidor Estado SES/SP) (GRIFOS NOSSOS)

O Ouvidor M-1 compreende a ação da ouvidoria enquanto controle social, quando a mesma oferece um espaço de troca com o usuário e enquanto instrumento de gestão, quando da geração de indicadores que venham a colaborar com discussões e mudanças, objetivando a melhoria da qualidade do serviço e da caracterização políticas de saúde.

"O papel da ouvidoria nessa Secretaria, eu costumo dizer que é baseado em três perspectivas: a ouvidoria tem que ter a função de controle social, ela tem que fazer essa interlocução do usuário, ela tem que gerar indicadores para o gestor, para que o mesmo possa qualificar a política de saúde que ele está utilizando". (Ouvidor M-1) (GRIFOS NOSSOS)

Percebe-se uma certa dificuldade para o Ouvidor M-2 descrever o objetivo da ouvidoria. 
“... sobre o objetivo, sobre filosoficamente, qual é a função verdadeira de uma ouvidoria, que tem um papel importantíssimo, principalmente nos dias de hoje. Então, eu noto sim, mas ao mesmo tempo eu noto, eu observo que eles cumprem o papel. Provavelmente, não fazem assim entendendo, com profundidade, o que é o meu trabalho, a essência do meu trabalho, mas por conta, até deste, peso que tem a ouvidoria, este estigma, estes termos inexplicável que eles têm, eles acabam fazendo um trabalho, onde o usuário é atendido conforme é seu direito." (Ouvidor M-2)

\title{
6.4.1 A Ouvidoria e a Gestão dos Serviços
}

É muito relevante compreender que não é papel da ouvidoria atuar enquanto gestor. Não é apropriado que a ouvidoria solucione problemas. $\mathrm{O}$ objetivo principal do ouvidor é de mediação. Ele não tem papel de executor. Quanto isto acontece provocar conflitos, e até mesmo, criar condições para que o usuário se utilize deste canal de forma clientelista e imediatista na solução de suas demandas particulares.

No entanto, esta não é a visão do Ouvidor M-2 ao relatar que o papel da ouvidoria é de solucionar problemas. Entende-se que esta atuação poderá comprometer o papel da ouvidoria bem como criar precedentes para que este tipo de demanda venha a se multiplicar, por parte dos usuários.

\begin{abstract}
"Eu tenho um grande desafio a cada momento que é solucionar problemas de pacientes que procuram a ouvidoria, principalmente visando ultrapassar filas enormes para exames complexos e quando 0 paciente precisa de cirurgia, quando esta no corredor de um hospital aguardando uma transferência... tenho um grande desafio quando o paciente está no pronto-socorro e diz pra mim, que não tem médico pra me atender. E eu digo para ele: "fique aí, do outro lado do telefone que Você será atendido". E, eu imediatamente faço meus contatos daqui, falo com o responsável, falo com quem quer que seja e o paciente no hospital será atendido. O que depende desta ouvidoria, eu vou até o fim, eu exploro es esgoto todas as possibilidades. Então, esta é a minha avaliação. Sem medo de errar, o usuário sempre tem razão." (Ouvidor M-2)
\end{abstract}

As queixas são efetuadas quase sempre no calor dos fatos o que acarreta uma dramaticidade maior aos eventos, nesse sentido, o Ouvidor deverá estar atento e preparado para mediar essas situações "limite".

Segundo WEIDLE (1995), o Ouvidor não tem o poder de interferir no cotidiano administrativo, nem de tomar decisões sobre o mesmo. $O$ ombudsman deve ter o poder de recomendar reparação quando as circunstâncias assim exigirem. Outrossim, a ouvidoria não deverá jamais 
desempenhar suas funções como um tipo de despachante categorizado, capaz de encaminhar solicitações isoladas de interesse pessoal.

Nesse sentido, a ouvidoria enquanto canal de participação social foi instituída para dar voz ao usuário, bem como, para ser um espaço de mediação de conflitos, decorrentes em função dos limites impostos pela saúde pública. Mediar as demandas dos usuários é tratá-las com neutralidade, verificando os dois lados, tanto do usuário quanto do trabalhador, dessa forma, agir com justiça, respeito, veracidade e clareza. Colabora o Ouvidor do Estado SES/SP.

"Nem sempre o usuário tem razão. Se, ele acha que tem, Você vai conversar com ele, vai mostrar, fazer entender qual é o caminho. Ele acha que tem que ser atendido, no dia que ele quer, e, não é por aí. Tem que entrar dentro do sistema. O Sistema tem um limite".(Ouvidor Estado)

Para GIANGRANDE (2001) é imprescindível analisar o fato, as circunstâncias em que o mesmo ocorreu e as razões expostas pelos dois lados.

Entretanto, no relato do Ouvidor M-2 verifica-se uma confusão com relação ao seu entendimento da rede pública de saúde e os limites por ela impostos. Percebe-se que em algum sentido o Ouvidor M-2 está atuando sozinho nesta ouvidoria, parece faltar um respaldo institucional.

"Uma ouvidoria como a minha, ela é amada e odiada. Eu apareço, eu faço contatos. Apareço assim no meu trabalho. Eu não fico só sentadinha. Eu tenho uma necessidade intrínseca de colaborar, ajudar, resolver, solucionar os problemas" (Ouvidor M-2)

A dificuldade de estabelecer um papel para a ouvidoria decorre principalmente da falta de envolvimento do gestor. Constituir uma ouvidoria não é uma responsabilidade somente do ouvidor, mas sim, de todos os envolvidos na administração pública. É necessário que o gestor aproprie-se deste processo e contribua na construção da proposta.

GIANGRANDE (2001) afirma que não se deve preconizar o ouvidor como uma panacéia, ou seja, a cura para todos os males.

Com relação ao tema, o Ouvidor do Estado SES/SP compreende que a ouvidoria não substituirá o gestor e não interferirá no processo. Deverá 
levantar demandas, apontar problemas, enfim dar elementos para que o gestor possa tomar a melhor decisão.

"Interferir não é o papel da ouvidoria como a gente fez todo o processo e como a gente foi construindo nesses anos todos... e eu continuo desde o início achando o papel do Ouvidor é de um técnico que conheça bem a estrutura de onde ele está localizado e ele não tem que estar substituindo o papel do gestor local. Ele tem é que estar contribuindo com os elementos para poder estar dizendo para o gestor... isto, isto, isto, o gestor é que vai dar a resposta." (Ouvidor do Estado SES/SP)

Portanto, considera-se que a ouvidoria não deverá ter ações executivas. É muito importante que o Ouvidor conheça o sistema de saúde no qual está inserido, bem como seus limites. Atue enquanto mediador de conflitos e estabeleça através das demandas levantadas, indicadores para subsidiar propostas e sugerir mudanças a serem pensadas pelo gestor.

\subsubsection{Geração de Indicadores}

Considera-se bastante importante na ação da ouvidoria a geração de indicadores derivados das demandas dos usuários. Ao se gerar indicadores a ouvidoria poderá recomendar mudanças, qualificar políticas públicas de saúde, modificar processos retro-alimentando o sistema, como elabora o Ouvidor M-1.
"É que realmente o serviço da ouvidoria conte com um serviço de atendimento ao usuário, que é realmente para ter essa entrada, de forma organizada e que isto gere indicadores e, que o ouvidor tenha este compromisso de gerar estes indicadores, colaborando com mudanças na política, ou edificar as políticas que estão sendo desenvolvidas por aí, se estamos seguindo o fluxo correto. Se alguém que está na função de ouvidoria, e não faz isto que é proposto acima, então ele não está na função de ouvidoria, ele deve ser um coordenador de SAC, mas a ouvidoria não dá pra não ser assim." (Ouvidor M-1)

Este enfoque mais administrativo da ouvidoria na saúde poderá ser um instrumental de grande valor para o administrador público que não tiver receio de lidar com estes dados, de forma a utilizá-los como desencadeadores de discussão e possíveis mudanças, na busca da transparência e visibilidade de sua administração. 
Villanova (1997), citado por LYRA (1995) afirma que o ouvidor ao agir como um crítico interno, a partir das demandas que the são encaminhadas, monta uma verdadeira radiografia da instituição. Com estes dados, elabora pareceres sobre as necessidades de mudanças nos seus procedimentos e normas, objetivando o aperfeiçoamento do desempenho e do relacionamento institucionais.

\subsubsection{Publicização do Trabalho da Ouvidoria}

A publicização dos resultados é um dos principais papéis dentro das ações a que se destina ouvidoria. Não foi possível encontrar nos sites das ouvidorias do Estado SES/SP, Secretaria Municipal da Saúde - M-1 e Secretaria Municipal da Saúde - M-2, um link que nos remetesse aos tipos de reclamação, encaminhamento das demandas as possíveis mudanças de estratégias ou de ações originadas através do acesso ao usuário.

Com relação a Ouvidoria Geral do SUS, por meio do último acesso realizado em maio de 2007, pôde-se localizar uma entrada para o relatório "A Ouvidoria e o seu Estado". Neste espaço encontra-se um mapa de todo o Território Nacional e ao clicar em cima de um Estado, depara-se com a síntese da atividade da ouvidoria SUS do mesmo, no período de abril a novembro de 2006.

Considera-se este relatório um grande avanço, pois através do mesmo inicia-se o processo de publicização. Apesar da simplicidade em que se apresenta, ele fornece ao leitor Informações importantes de como se dá o acesso e o tratamento dos dados por esta ouvidoria, as tipificações das demandas e as estatísticas de reclamações por cidade em todo o País.

Contudo, entende-se que a publicização no setor saúde e especificamente no setor público deve ser priorizada, tendo em vista uma maior transparência na gestão, colaborando para a discussão de políticas públicas gerais ou regionalizadas.

Segundo Cunill Grau (1987) citado por BELLISOMI (2003), a ampliação da esfera pública, isto é, do espaço coletivo de discussão da coisa pública na sociedade gera maior crítica e controle da sociedade sobre 0 
Estado e, ao mesmo tempo, um aumento da demanda pela publicização dos atos governamentais.

Segundo LYRA (1995) é aconselhável que o ouvidor público disponha de espaços nos meios de comunicação, para ampliar sua capacidade de intervenção e tornar mais transparentes suas ações. Uma coluna em um jornal de circulação local ou um programa de rádio podem ser utilizados, de acordo com as condições do município.

Possivelmente, uma publicização via mídia escrita ou falada, Internet, jornais, revistas, conforme o número de acessos e/ou importância das demandas levantadas, poderá ser uma estratégia valiosa para que a população fique mais atenta às questões da saúde. Neste sentido, a publicização contribuirá para que a população compreenda o papel da ouvidoria, como uma oportunidade para o gestor mostrar seu trabalho e divulgar as ações e propostas de mudanças frente às demandas levantadas.

Com relação a esta questão, o Ouvidor $\mathrm{M}-1$, relata que a publicização é um dos projetos desta ouvidoria.

\footnotetext{
"Então, nos fizemos nosso projeto para o planejamento de 2006, e dentro do planejamento a gente fez uma solicitação, que além de gerar estes indicadores pro gestor, sugerimos que eles sejam publicados com uma certa periodicidade, porque a gente acha que isto tem que ficar publicado. Mas, isto está encaminhado e a gente vai ter que ver o que vai ser dessa sugestão que a gente deu, se vai ser aprovada ou não".(Ouvidor M-1)
}

SENEVIRATNE (2002), no seu Livro: Ombudsmen: public services and administrative justice, no capítulo: O Ombudsmen no serviço de saúde elabora um capítulo sobre a publicidade da ouvidoria na saúde. A autora entende que existe uma preocupação, pois, são poucas as pessoas que sabem da existência do ombudsman na saúde. A legislação Inglesa prevê uma publicidade mínima, principalmente dos relatórios parciais, o que não acontece. Somente, se faz um relatório anual que é entregue ao Parlamento.

Em 1996, na Inglaterra, elaborou-se vários folders com informações veiculadas em linguagem clara e também para deficientes visuais que foram enviados à todas as unidades de saúde da família. Afirma a autora que o Ombudsmen da saúde possui um website informativo, e que o mesmo utiliza- 
se de várias oportunidades para explicar seu trabalho na mídia, incluindo jornais.

Relata o Ouvidor M-1, sobre a publicização da ação da ouvidoria:

"Com relação à população, a gente entende que deveria ser feita uma divulgação. Há coisa de uns 4 meses atrás, emissora de TV que é a Rede Globo local, ela fez uma matéria sobre a ouvidoria na saúde. Ela veio até aqui, ela entrevistou o Secretário Adjunto, e fez uma matéria explicando, a ouvidoria e como ela funcionava. Então, nessa ocasião, teve uma divulgação, mas a gente não percebeu nenhuma mudança significativa da vinda dos usuários para cá. Então, nós não temos uma publicização de que este serviço existe, as pessoas vêm e dizem, ah! Eu não sabia, e tal! A gente percebe que a clientela que vem aqui, os usuários, eles ficam sabendo pelo próprio munícipe. $A$ gente tem um projeto que também foi para o planejamento da ouvidoria, que é para não ficar nessa posição passiva, que é acolher somente o munícipe que vem aqui. São duas perspectivas uma é a gente colocar em todos os locais e isto está dentro do decreto e todos os locais sejam da rede pública ou de prestadores de serviços também uma espécie de caixa de sugestão que seria da ouvidoria e ali a gente coletaria queixas, sugestões, etc. Esta também seria uma forma passiva, mas teria a presença da ouvidoria, através da caixa de sugestão em cada unidade. E a outra intenção é fazer pesquisa com o munícipe. Fazer uma pesquisa ativa periódica. Fazer essa comparação de dados, mas, isto a gente não realizou ainda. Ainda é um projeto."(Ouvidor M-1)".

Desse modo, CENTURIÃO (2001) diz que é importante promover a interface da organização com os órgãos de imprensa e as entidades sociais. Além de preservar a imagem da instituição, o ouvidor consolida a credibilidade pública com de uma postura ética e responsável, especialmente em momentos de crise.

Todavia OLIVEIRA (2005), entende que a publicidade dos atos do ouvidor, alertará a população sobre o vigor de sua existência e, ao mesmo tempo, demonstrará aos dirigentes a maturidade da instituição na sua relação com a comunidade.

No entanto, é necessário ter claro qual o objetivo da ouvidoria, bem como seus limites de atuação, para não criar por meio da publicização, situações fantasiosas ou até mesmo servir como propaganda partidária, comprometendo profundamente o seu o papel. 


\section{CONSIDERAÇÕES FINAIS}

Pôde-se verificar neste estudo, que a ouvidoria no Brasil possui um formato diferente da proposta tradicional, ou seja, na sua grande abrangência a mesma aparece sempre ligada ao poder executivo, nas suas diversas instâncias, com isso, sua ação torna-se muito mais próxima do cidadão do que as ouvidorias de outros países, como discutido na introdução.

Estudou-se as ouvidorias na saúde, nos três níveis de gestão: federal, estadual e municipal, e percebeu-se que:

Com relação à caracterização dos sites, a Ouvidorias Geral do SUS, Estado SES/SP e Secretaria Municipal da Saúde - M-1, destacam o grande interesse em se construir um canal de comunicação com o cidadão. Entretanto, ainda é necessário incrementar este canal com mais informações, inclusive quanto ao papel da ouvidoria, bem como ampliar as formas de publicização.

Como a Ouvidoria da Secretaria Municipal de Saúde - M-2, ainda não havia constituído um site é importante investir neste canal de comunicação, para que seja ampliado o espaço de participação social.

Apesar do pouco tempo de implementação deste novo ator institucional, entende-se que todas as ouvidorias estudadas estão em processo de construção, organizando-se mesmo que minimamente para o desenvolvimento do seu papel.

A Ouvidoria SUS poderia enquanto Departamento do Ministério da Saúde, mapear todas as ouvidorias do Território Nacional, disponibilizar essas informações no seu site, para facilitar o acesso do usuário e agilizar o encaminhamento da maior parte das demandas.

Em todas as ouvidorias estudadas, chamou a atenção a grande diversidade de enfoques revelados por meio dos relatos. Isto mostra a necessidade de reflexões mais aprofundadas a respeito da conceituação destas ouvidorias, seus objetivos e missão.

Considera-se que a Ouvidoria Geral do SUS deveria ter como um dos seus objetivos precípuos, discutir esta questão com a rede pública, e como 
num um exercício de democracia, elaborar um conceito básico para ouvidoria nesta área da saúde.

Quanto à abordagem do cidadão, a Ouvidoria Geral do SUS, Ouvidoria do Estado SES/SP e Ouvidoria da Secretaria Municipal da Saúde - M-1, procuram adequar as demandas e encaminhá-las de acordo com os limites estabelecidos pela rede pública, bem como, utilizam essas informações como um instrumento de gestão.

A Ouvidoria da Secretaria Municipal da Saúde - M-2, demonstra nos seus relatos que chega a atuar de forma voluntariosa na sua relação com o usuário, no momento das queixas. Por entender que o "usuário tem sempre razão", acaba por confundir o papel da ouvidoria, agindo muitas vezes, de forma clientelista e paternalista na sua relação com o mesmo. Acredita-se que essa concepção não ajuda nem a construção de uma ouvidoria eficiente, nem a formação de um cidadão esclarecido.

Contudo, o envolvimento do gestor e dos trabalhadores da área da saúde, na discussão e implementação da ouvidoria, corrobora com uma maior autonomia e liberdade ao ouvidor e permite a ampliação dos espaços de troca e melhoria na qualidade do serviço.

Algumas questões referentes ao papel da ouvidoria merecem estudos posteriores, como por exemplo, o que concerne à relação dos trabalhadores da saúde e a ouvidoria; o frágil limite que separa a ouvidoria e clientelismo; ouvidoria e conflitos de interesse; e a compreensão do gestor público sobre o papel da ouvidoria na saúde.

Finalizando, fez-se um exercício, na tentativa de elaborar uma orientação para a estruturação de ouvidorias na área da saúde, como contribuição e ponto de partida para discussões e novos estudos. (Anexo 1). 


\section{REFERÊNCIAS BIBLIOGRÁFICAS}

1. Agência Nacional de Energia Elétrica. ouvidoria - história. www.aneel.gov.br. [Texto retirado da Internet]

2. Alvarez MC. Controle social: notas em torno de uma noção polêmica. São Paulo Perspec. v.18 n.1 São Paulo jan./mar. 2004.

3. Amaral $F^{\circ}$ MJT do. $O$ ombudsman e o controle da administração. São Paulo. Cone; 2000.

4. Araújo NMS. Implantação do serviço de ouvidoria do sistema municipal de saúde. Experiências Inovadoras no SUS: Relatos de Experiências: Gestão dos Serviços de Saúde. 2. Brasília, Brasil. Ministério da Saúde; 2002.

5. Assunção Ada Ávila, Belisário Soraya Almeida, Campos Francisco Eduardo, D'Ávila Luciana Souza. Recursos humanos e trabalho em saúde: os desafios de uma agenda de pesquisa. Cad. Saúde Pública [periódico na Internet]. [citado 2007 Ago 18]. Disponível em: http://www.scielo.br/scielo.php?script=sci_arttext\&pid=S0102311X2007001400009\&Ing=pt\&nrm=iso.

6. Bava SC. Cidadania, Participação Popular e Controle Social: Conceitos e Práticas in: Coleção Debates, Série 2, Políticas Públicas em Saúde: Controle Social no SUS: A Prática e os Desafios. Instituto de Saúde - SES/SP, 1995.

7. Brasil. Constituição da República Federativa do Brasil. São Paulo, Atlas, $23^{\mathrm{a}}$. Ed; 2004.

8. Brasil. Dispõe sobre a proteção do consumidor e dá outras providências, Lei no. 8.078, Brasília, 11 de setembro de 1990.

9. Brasil. Dispõe sobre as condições para a promoção, proteção e recuperação da saúde, a organização e o funcionamento dos serviços correspondente e dá outras providências, Lei no. 8.080, Diário Oficial da União, Brasília, 19 setembro de 1990.

10. Brasil. Ministério da Saúde. Secretaria Executiva. Departamento de Apoio à Descentralização. Coordenação-Geral de Apoio à Gestão Descentralizada. Diretrizes operacionais dos Pactos pela Vida, em Defesa do SUS e de Gestão / Ministério da Saúde, Secretaria Executiva, Departamento de Apoio à Descentralização. Coordenação-Geral de Apoio à Gestão Descentralizada. - Brasília:

11. Brasil. Ministério da Saúde. Secretaria Executiva. Secretaria de gestão Estratégica e Participativa. Glossário Temático: Ouvidoria SUS - Brasília: Editora do Ministério da Saúde, 2007. 48p.

12. Camargo e Gomes ME. Do Instituto do Ombudsman à Construção das Ouvidorias Públicas no Brasil. In: Rubens Pinto Lyra et al., A ouvidoria na esfera pública brasileira. $1^{1}$ Edição. Curitiba: Editora Universitáira/UFPB; 2000. P. 49-124.

13. Campos GWS. A Falseta Liberal e a saúde (a face totalitária do neoliberalismo) in: A Saúde Pública e a Defesa da Vida, Editora Hucitec, São Paulo, 1991.

14. Campos GWS. A gestão enquanto componente estratégico para a implantação de um Sistema Público de Saúde in: A Saúde Pública e a Defesa da Vida, Editora Hucitec, São Paulo, 1991 
15. Campos GWS. Sobre la reforma dos modelos de atencion: um modo mutante de hacer salud in: Política de Saúde: O Público e o privado, Ed. Fiocruz, Rio de Janeiro, 1996.

16. Contrandiopoulos AP, Champagne F, Potvin L, Denis JL, Boyle P. Saber preparar uma pesquisa. São Paulo/Rio de Janeiro, Hucitec-ABRASCO, 1994.

17. Cohn A. Saúde e Cidadania: Análise de uma Experiência de Gestão Local in: Política de Saúde: O Público e o Privado, Ed. Fiocruz, Rio de janeiro, 1996

18. COSTA, Rogério da. Sociedade de controle. São Paulo Perspec. [online]. 2004, vol. 18, no. 1 [citado 2006-11-14], pp. 161-167. Disponível em: $<$ http://www.scielo.br/scielo.php?script=sci_arttext\&pid=S0102-

$88392004000100019 \& \operatorname{lng}=p t \& n r m=i S O>$. ISSN 0102-8839. doi: $10.1590 / S 0102-$ 88392004000100019

19. Cartwright DP. Analisis del material cualitativo. In: Festinger L Katz D. Los metodos de investigación en las ciencias sociales. Buenos Aires, Pardós, 1976.

20. Dallari SG. Organização jurídica da administração pública em saúde. In: Rozenfeld S. Fundamentos da Vigilância Sanitária. Rio de Janeiro, Fiocruz, 2000. p. 113-133.

21. Dallari DA. A separação de poderes e as funções do Estado in: Elementos da Teoria Geral do Estado. São Paulo, Saraiva, 2007, 26ª . Ed.

22. Damaso R. Justiça social e cidadania da saúde: para uma crítica da Moral Sanitária in: Política de Saúde: O Público e o Privado, Ed. Fiocruz, Rio de Janeiro, 1996.

23. Di Pietro MSZ. Direito administrativo. São Paulo. Atlas, $2003,15^{\mathrm{a}}$ ed.

24.E RB. Abordagens Teóricas da Política Social e da Cidadania. [sem autores definidos, retirado do site: http://www.univap.br/ gpaiva/Pol arquivos/POL-05.htm - acessado em 20/11/2006]

25. Gil AC. Métodos e técnicas de pesquisa social. São Paulo: Atlas; 1994.

26. Guimarães MS. Ministério público, ombudsman e ouvidor na fiscalização dos serviços públicos. [online]. [disponível em: http://www.amperi.org.br/port/marcio01body.htm] [2004 out 6]

27. Foucault M. A Crise Atual da Medicina. Primeira Conferência pronunciada pelo pensador francês por ocasião da série de palestras sobre história da medicina que realizou, em 1974, na Instituto de Medicina Social da universidade do Estado do Rio de Janeiro, Transcrição, 1974

28. Jacobi, P. Participação e gerência dos Serviços de Saúde: desafios e limites no município de São Paulo. Revista de Administração Pública 1992"26(2): 32-34.

29. Júnior NC, Elias PE. Controle público e eqüidade no acesso a hospitais sob gestão pública não estatal. Rev Saúde Pública 2006;40(5):914-20.

30. Laurell AC. Avançando em direção ao passado: a política social do neoliberlismo in: Estado e Políticas Sociais no Neoliberalismo, Ed. Cortez, São Paulo, 1995.

31. Lacerda AV de. As ouvidorias do Brasil colônia. Curitiba: Juruá; 2000.

32. Lara Pinto O. Ombudsman nas instituições bancárias do Brasil agente de mudanças. Brasília; 1993. [Tese de Mestrado apresentada à 
Faculdade de Estudos Socias Aplicados - Departamento de Administração, Universidade de Brasília.

33. Lüdke M \& André M.E.D.A (2001). Pesquisa em educação: abordagens qualitativas. São Paulo: EPU; 1986 (6 reimpressão)

34. Lyra P R (1995). Ouvidoria Pública. In Rubens Pinto Lyra (org.)., Ouvidorias Públicas no Brasil. 1‥ Edição. Paraíba. Editora CEDDHC. P. 39-41.

35. Madrazzo J. citado por: Camargo e Gomes ME. Do Instituto do Ombudsman à Construção das Ouvidorias Públicas no Brasil. In: Rubens Pinto Lyra et al., A ouvidoria na esfera pública brasileira. $1^{3}$ Edição. Curitiba: Editora Universitária/UFPB; 2000. P. 49-124.

36. Minayo MCS . O desafio do conhecimento. pesquisa qualitativa em saúde. São Paulo/ Rio de Janeiro: Hucitec/Abrasco; 1994.

37. Ministério da Saúde. Portaria no. 115: disciplina o funcionamento do Departamento de Ouvidoria-Geral do Sistema Único de Saúde. Brasília, 17/06/04. Sec. I. p.1.

38. Ministério da Saúde. Portaria Conjunta no. 1.112: Instituir no Ministério da Saúde, Grupo de Acompanhamento da Responsabilização - GAR decorrente das ações levadas a efeito pelo controle externo e Interno da Administração e dos reclamos dos usuários do Sistema Único de Saúde. Brasília, 29/09/2000.

39. Ministério da Saúde. Padrões de atendimento ao cidadão: manual técnico para implantação dos padrões de qualidade do atendimento ao cidadão. Brasília, 2002, $1^{3}$ Ed.

40. Ministério da Saúde, Secretaria de Gestão Participativa, Departamento de Ouvidoria Geral do SUS - Atividades do Departamento de Ouvidoria Geral do SUS

41. Ministério da Saúde, Organograma do Disque Saúde, Brasília (s/data) [retirado da Ouvidoria Geral do SUS em Julho/2006].

42. Ministério da Saúde, Folheto Informativo: A Saúde Ouve Você, Brasília (s/data) - [retirado da Ouvidoria Geral do SUS em julho/2006]

43. Ouvidoria Geral do Município de São Paulo - Relatório 2005 [http://ww2.prefeitura.sp.gov.br//arquivos/ouvidoria/balanco/2005/ouvidoria relatorio_2005.pdf]

44. Paim Jairnilson Silva, Teixeira Carmen Fontes. Política, planejamento e gestão em saúde: balanço do estado da arte. Rev. Saúde Pública. [periódico na Internet]. 2006 Ago [citado 2006 Nov 03]; 40(spe): 73-78. Disponível em: http://www.scielo.br/scielo.php?script

45. Pereira LH. Ouvidoria Hospitalar: disciplinamento e envolvimento como estratégias rumo à democratização. Tese de Doutoramento. Universidade Federal do Rio Grande do Sul. Instituto de Filosofia e Ciências Humanas, Dez. 2000.

46. Pinski I. A influência do ombudsman na eficácia empresarial. São Paulo; 2003. [Tese de Mestrado apresentada à Faculdade de Economia, Administração e Contabilidade da Universidade de São Paulo]

47. Ramos CL. Conselhos de Saúde e Controle Social in: Política de Saúde: O Público e o privado, Ed. Fiocruz, Rio de Janeiro, 1996.

48. Roldão AJ da V. A Ouvidoria na Empresa Brasileira dos Correios e Telégrafos. In: Rubens Pinto Lyra et al., A ouvidoria na esfera pública 
brasileira. $1^{\sharp}$ Edição. Curitiba: Editora Universitária/UFPB; 2000. P. 49124.

49. São Paulo. Lei no. 10.294, de 20 de abril de 1999. Estabelece a criação do Sistema Estadual de Defesa do Usuário de serviços Públicos SEDUSP. Diário Oficial do Estado, São Paulo, Seção II. p.1

50. São Paulo (Estado). Lei Complementar no. 79109 de março de 1995. Projeto de Lei Complementar no.15/91 do Deputado Roberto Gouveia e outros. Código de saúde de São Paulo. São Paulo, março 1995.

51.São Paulo (Município). Decreto no. 40.248, de 12 de janeiro de 2001. Institui junto ao Gabinete da Prefeita, a Ouvidoria Geral do Município de São Paulo. Diário Oficial do Município, São Paulo, set, 2001.

52. Secretaria do Estado da Saúde da Paraíba. Governo do Estado da Paraíba. Site da Ouvidoria da Secretaria do Estado da Saúde da Paraíba. [http://www.saude.pb.gov.br/web_data/Ouvidoria/missão, acesso em 14 de maio de 2005],

53. Secretaria do Estado da Saúde - SES/SP: Ouvidoria da Saúde: Disque SUS: A Figura do "Ombudsman" - Defensor do Povo e os Direitos Humanos. Profa. Elza Ferreira Lobo (s/d).

54. Secretaria do Estado da Saúde de Santa Catarina. Site. [[http://www.saude.sc.gov.br/cidadão/ouvidoria/ouvidoria_paraque.htm, acesso em abril de 2005], (s/d)

55. Serapioni M, Romaní O. Potencialidades e desafios da participação em instâncias colegiadas dos sistemas de saúde: os casos de Itália, Inglaterra e Brasil. Cad. Saúde Pública, Rio de Janeiro, 22(11):2411-2421, nov, 2006.

56. Stotz EM. Cidadania, Participação Popular e Controle Social: Conceitos e Práticas in: Coleção Debates, Série 2, Políticas Públicas em Saúde: Controle Social no SUS: A Prática e os Desafios. Instituto de Saúde - SES/SP, 1995.

57. Triviños, ANS. Introdução à pesquisa em ciências sociais: a pesquisa qualitativa em educação. São Paulo, Atlas, 1987.

58. Vismona EL. A Ouvidoria no Brasil e seus Princípios. In: A ouvidoria no Brasil. Associação Brasileira de Ouvidores. $1^{\text {a }}$ edição. São Paulo Câmara Brasileira do Livro; 2001. p. 11-20.

59. Vismona EL. A experiência dos ouvidores públicos. Cadernos FUNDAP 2001; 22: 160-168.

60. Westphal, MF. Participação popular e políticas municipais de saúde: Cotia e Vargem Grande Paulista. São Paulo, 1992. [Tese de Livre-Docência, apresentada à Faculdade de Saúde Pública da USP] 


\section{BIBLIOGRAFIA CONSULTADA}

Belissomi M de A. Responsabilização e eficiência: a ouvidoria da cidade de Santo André. São Paulo; 2003. [Tese de Mestrado apresentada à Escola de Administração de Empresas de São Paulo, Fundação Getúlio Vargas].

Centurião A. Ombudsman: a face da empresa cidadã. São Paulo. Educator, 2003.

Cruz MS. Tecnologia da informação no espaço público: o caso Telecidadão no Paraná. São Paulo, 1999. [Tese de Mestrado apresentada à escola de Administração de Empresas de São Paulo da Fundação Getúlio Vargas].

Di Pietro MSZ. Parcerias na administração pública: concessão, permissão, franquia, terceirização e outras Formas. São Paulo. Atlas, 2002, $4^{3}$ ed.

Drucker PF. Administração, Responsabilidade, Tarefas e Práticas. Ed. Pioneira, 1‥ ed., São Paulo, 1975

Foucault M. Microfísica do Poder. Ed. Graal, 11. Ed. Rio de janeiro, 1979.

KISSLER L. Ética e Participação: problemas associados à Gestão Participativa nas Empresas. Florianópolis, UFSC. 2004.

Paes AMC. Silva FR, O MLC. A ouvidoria em serviços de saúde exercício da cidadania: A experiência do hospital de base do Distrito Federal (HBDF). Revista de Saúde do Distrito Federal, n. 9, no. 3, jul/set. 1998.

Rossi SC. O Controle externo sobre a administração pública. Cadernos Fundap. No. 22, 2001: p.169-174.

Santos BS et al. Democratizar a democracia: Os caminhos da democracia participativa. Rio de Janeiro, Civilização Brasileira, 2002.

Singer P, Campos O, Oliveira EM. Prevenir e Curar: 0 controle social através dos serviços de saúde. Ed. Forense Universitária, Rio de Janeiro, 1987. 


\section{Anexo 1 \\ Orientação Básica de Estruturação de Ouvidoria na Saúde}

\section{Conceito de Ouvidoria}

Sugere-se que, o ouvidor juntamente com o Gestor Central, busquem uma proposta para a instituição de uma ouvidoria na saúde dentro daquela instituição. Sem esta conceituação básica, e sem a participação destes atores nesta construção, possivelmente o objetivo da ouvidoria ficará comprometido.

Sugere-se abaixo um conceito amplo de ouvidoria:

Conceito Amplo

De Ouvidoria:
A ouvidoria na saúde é um canal de comunicação destinado ao usuário/cidadão, fornecedores, prestadores de serviços, trabalhadores da saúde, possam fazer reclamações, queixas, sugestões, elogios e denúncias, relativas aos serviços de saúde. Através deste acesso, será possível, discutir e propor melhorias no serviço de saúde, e com isto melhorar a qualidade do serviço prestado à população.

\section{Das Demandas:}

Com relação ás demandas, o site da Ouvidoria do Estado da Saúde de de Santa Catarina (2005)

[http://www.saude.sc.gov.br/cidadão/ouvidoria/ouvidoria_paraque.htm, acesso em abril de 2005] colabora com as seguintes definições:

Reclamações: queixas, manifestações de desagrado, protestos;

Denúncias: é mais grave do que uma simples queixa, reclamação.

Significa dar a conhecer, delatar um fato em caráter sigiloso;

Sugestões: idéias, propostas de mudanças submetidas a apreciação da instituição;

Elogios: reconhecimento, demonstração de satisfação para com o serviço recebido;

Informações: solicitação de alguma referência (endereço, atendimento, horário de funcionamento da unidade, nome do responsável). 


\section{Objetivo da Ouvidoria na Saúde}

A ouvidoria na saúde tem como papel básico atuar como um canal de comunicação com o usuário abrindo possibilidades para que o mesmo se manifeste, positiva ou negativamente, bem como, através das demandas levantadas estabeleça indicadores que subsidiem o gestor na discussão de políticas públicas de saúde, novos programas e rever atos e ações administrativas, sendo um canal de participação da comunidade e também um instrumento de gestão, propondo a melhoria da qualidade dos serviços de saúde.

Com a contribuição de texto originado de discussão sobre ouvidoria na saúde elaborado juntamente pela Professora Elza Ferreira Lobo, atual Ouvidora da Secretaria do Estado da Saúde de São Paulo SES/SP, Professor Paulo Fortes, Professor Associado da Faculdade de Saúde Pública da USP e por Simone Ribeiro Spinetti, aluna de pós-graduação nível doutorado da Faculdade de Saúde Pública da USP. (s/d), expõe-se:

\section{Objetivos da Ouvidoria:}

- Recomendar correção de falhas administrativas;

- Solicitar esclarecimentos sobre a violação de direitos dos usuários dos serviços de saúde;

- Fazer sugestões e propostas de melhoria da qualidade de organização e funcionamento dos serviços de saúde;

- Prevenir e recomendar correção de atos e procedimentos contrários aos princípios da administração pública;

- Aperfeiçoar formas de participação da comunidade no acompanhamento e fiscalização dos serviços de saúde.

\section{A Escolha do Ouvidor na Saúde}

A escolha do ouvidor deverá ser baseada na relação de confiança, entre o executivo e o ouvidor, sem esta relação possivelmente este canal ficará comprometido. 
Sugere-se que o ouvidor deverá trabalhar, na medida do possível, com um assistente de ouvidoria, mas não com dois ouvidores, o que poderia causar confusão com relação ao referencial para o cidadão.

\section{Competências do Ouvidor:}

Enquanto competências do Ouvidor recomenda-se conforme literatura da Secretaria de Estado da Saúde de São Paulo SES/SP (s/d), e Secretaria do Estado da Saúde Santa Catarina, retirada do site [http://www.saude.sc.gov.br/cidadão/ouvidoria/ouvidoria_paraque.htm, acesso em abril de 2005]:

- Buscar a participação social;

- Fornecer informações gerais sobre a estrutura de atendimento e funcionamento das unidades de competência da Secretaria;

- Receber críticas, reclamações e/ou sugestões referentes aos serviços prestados;

- Apurar procedência das reclamações e denúncias apresentadas;

- Discutir, polemizar, inovar, ampliar a discussão sobre a gestão administrativa com vistas a seu aperfeiçoamento;

- Publicizar informações sobre comportamentos administrativos;

- Investigar as denúncias vindas a seu conhecimento, que podem ser apresentadas sem qualquer formalidade, em havendo necessidade, repassá-las ao Ministério Público;

- Recomendar privada ou publicamente aos funcionários envolvidos que modifiquem algum comportamento administrativo considerado insatisfatório;

- Identificar e avaliar, através de dados estatísticos, o grau de satisfação da população com relação aos serviços executados, de acordo com os princípios e diretrizes do SUS;

- Obter informações para o gerenciamento do SUS;

- Sugerir medidas de aperfeiçoamento das atividades da Secretaria;

- Elaborar relatórios públicos de sua atuação. 
Não é Competência do Ouvidor:

- Fazer o primeiro atendimento aos usuários/cidadãos devendo contar a ouvidoria como uma rede de apoio: SAC, Disque SUS, etc.

- Acolher sugestões de como desenvolver uma política pública;

- Dar prosseguimento a reclamações que ainda não tiverem sido apresentadas à instituição de saúde reclamada. A ouvidoria deverá atuar como uma segunda instância de reclamação, diminuindo o volume e aumentando a atenção para os casos mais relevantes;

- Na medida do possível, não deverá o ouvidor, receber demandas de terceiros, que não seja o interessado, evitandose, assim, intermediações que poderiam dar margem à explorações inadequadas.

\section{Papel do Ouvidor na Saúde}

\section{Conhecer o SUS}

O Ouvidor Geral do SUS, em qualquer instância de atuação, deverá basear sua ação nos princípios do SUS conhecendo-os profundamente, bem como, acompanhar o desenvolvimento de programas e ações na área. Esta é uma condição primordial para o desempenho da função de ouvidor nesta área.

\section{Conhecer o Perfil do Usuário da Saúde do SUS}

O usuário da saúde é toda pessoa que acessa o serviço de saúde de forma direta: recepção, consultas médicas, psicológicas, serviço social, enfermagem, retirada de medicamentos, exames, etc., bem como, indiretamente requerendo informações sobre o serviço disponibilizado. 


\section{Papel do Usuário x Ouvidor}

O usuário é o ponto central da ouvidoria da saúde e, o grande desafio da ouvidoria. É preciso reconhecer que este é o ator central da criação de toda a qualquer ouvidoria.

Frente a esta relação o ouvidor deverá:

- Ouvir - saber ouvir, com atenção, sem preconceitos, discriminação.

Ouvir as duas parte, de forma imparcial e neutra, mediar as partes envolvidas de forma justa, ética e responsável.

- Agir pedagogicamente - informar e esclarecer o usuário, sobre seus direitos e deveres, também sobre os limites da rede pública, agindo de forma a:

- Mediar - verificar entre as partes envolvidas todas as informações possíveis, visando sempre uma solução justa;

- Resolutividade - dar retorno positiva ou negativamente ao usuário, sempre o esclarecendo sobre o processo que culminou nesta decisão.

É possível dentro do escopo acima, fazer com que a ouvidoria venha a:

- Atenuar conflitos;

- Orientar correções;

- Esclarecer situações conflitivas; e

- Evitar processos agindo em tempo oportuno .

\section{Conhecer o Sistema de Saúde e seus Limites}

O Ouvidor deverá conhecer e entender o sistema de saúde vigente em seu Estado, Município. Compreender os limites que se estabelecem em cada região, sem estas informações seu trabalho ficará comprometido. As reclamações dos cidadãos poderão contribuir para que estes limites possam ser discutidos com o gestor local. 
Outra questão relevante ao ser levantada uma demanda, é que o ouvidor deverá entender como se estabelece a rotina daquele equipamento de saúde alvo de reclamações. Esta compreensão de como se efetiva esta rotina, poderá contribuir de forma bastante importante para uma decisão imparcial e que não venha a desautorizar o equipamento de saúde, frente à organização dos serviços já existente, atuando sob a forma de imposição. Ouvir ambas as partes é fundamental.

\section{Conhecer os Direitos e Deveres dos Usuários de Serviços}

\section{Públicos de Saúde}

O usuário de serviço de saúde tem em defesa de seus direitos a Carta dos Direitos dos Usuários da Saúde do Ministério da Saúde cujo âmbito é nacional.

A Carta dos Direitos dos Usuários da Saúde remete-nos aos direitos e também aos deveres dos usuários, ou seja, o usuário também tem responsabilidades na sua relação com os profissionais e serviços de saúde.

Basicamente, a Carta traz os seguintes tópicos:

- Todo cidadão tem direito ao acesso ordenado e organizado aos sistemas de saúde.

- Todo cidadão tem direito a tratamento adequado e efetivo para seu problema.

- Todo cidadão tem direito ao atendimento humanizado, acolhedor e livre de qualquer discriminação.

- Todo cidadão tem direito a atendimento que respeite a sua pessoa, seus valores e seus direitos.

- Todo cidadão também tem responsabilidades para que seu tratamento aconteça da forma adequada.

- Todo cidadão tem direito ao comprometimento dos gestores da saúde para que os princípios anteriores sejam cumpridos.

\section{Conhecer os Deveres dos Usuários de Serviços Públicos de}

\section{Saúde}

Com relação aos deveres a Carta contribui, com as seguintes informações:

\section{Todo cidadão deve se comprometer a:}

- Prestar informações apropriadas nos atendimentos, nas consultas e nas internações sobre:

- queixas, enfermidades e hospitalizações anteriores, história de .. uso de mediramentase/nu 
- drogas, reações alérgicas e demais indicadores de sua situação de saúde.

- Manifestar a compreensão sobre as informações e/ou orientações recebidas e, caso subsistam dúvidas, solicitar esclarecimentos sobre elas.

- Seguir o plano de tratamento recomendado pelo profissional e pela equipe de saúde responsável pelo seu cuidado, se compreendido e aceito, participando ativamente do projeto terapêutico.

- Informar ao profissional de saúde e/ou à equipe responsável sobre qualquer mudança, inesperada de sua condição de saúde.

- Assumir responsabilidades pela recusa a procedimentos ou tratamentos recomendados e pela inobservância das orientações fornecidas pela equipe $d$ e saúde

- Contribuir para o bem-estar de todos que circulam no ambiente de saúde, evitando, principalmente ruídos, uso de fumo, derivados do Tabaco e bebidas alcoólicas, colaborando com a limpeza do ambiente.

- Adotar comportamento respeitoso e cordial com os demais usuários e trabalhadores da saúde

- Ter sempre disponíveis para apresentação seus documentos e resultados de exames que permanecem em seu poder.

- Observar e cumprir o estatuto, o regimento geral ou outros regulamentos do espaço de saúde, desde que estejam em consonância com esta carta.

- Atentar para situações da sua vida cotidiana em que sua saúde esteja em risco e as possibilidades de redução da vulnerabilidade ao adoecimento.

- Comunicar aos serviços de saúde ou à vigilância sanitária irregularidades relacionadas ao uso e à oferta de produtos e serviços que afetem a saúde em ambientes públicos e privados.

- Participar de eventos de promoção de saúde e desenvolver hábitos e atitudes saudáveis que melhorem a qualidade de vida.

Outras responsabilidades pertinentes aos cidadãos usuários de serviços públicos de saúde:

- Ater-se ao dia e horário da sua consulta. Na impossibilidade de comparecer, tentar na medida do possível avisar com antecedência o serviço, para que seja possível, repassar a vaga a outro usuário que necessite;

- Ater-se à marcação de exames, medicamentos, etc. Em caso de dúvida, requerer informações, quantas vezes for necessário;

O que não poderá ocorrer e possivelmente comprometerá papel da ouvidoria é que a mesma seja utilizada para outros fins como serviço social, 
marcação de consultas, priorização de usuários reclamantes, clientelismo, etc. podendo estas práticas serem multiplicadas pelos usuários criando-se, assim, um círculo vicioso que poderá comprometer tanto o papel da ouvidoria, como do gestor, uma vez que, se houver um aumento de demanda destas práticas muito provavelmente a ouvidoria não conseguirá comportar a demanda geradas pelos usuários, estabelecendo-se, assim, conflitos nas relações entre a ouvidoria a gestão e o usuário.

\section{Conhecer Quem é o Trabalhador da Saúde}

Por trabalhador da saúde entende-se ser o conjunto de profissionais de saúde que trabalham na prestação de serviços de saúde, em estabelecimentos de saúde, o qual convencionou-se chamar de pessoal da saúde. (ASSUNÇÃO et al, 2002)

O ouvidor tem como função básica disseminar o seu papel para que os trabalhadores da saúde, não venham a ter uma compreensão errônea de sua ação, confundindo-a com outros canais como a auditorias, ou entendendo-a enquanto órgão punitivo e coator.

Deverá o Ouvidor esclarecer clara e objetivamente o papel da Ouvidoria para que esta relação não fique comprometida criando-se assim, relações de disputa e força ou fazendo com que não haja um envolvimento destes atores, minimizando as demandas da ouvidoria, comprometendo sua efetividade. Faz-se muito importante sensibilizar os trabalhadores da saúde, em todos os seus níveis de atuação como forma de parceria.

Assim, como os cidadãos, entende-se que os profissionais da saúde também têm deveres e direitos na sua relação com o usuário e com a Ouvidoria.

Deveres: Os trabalhadores da saúde deverão cumprir o que é proposto enquanto política de saúde estabelecida pelo gestor central,. Na interface com o cidadão deverá buscar a cortesia, exercer com competência e dedicação seu trabalho, colaborar com as solicitações da ouvidoria e contribuindo ao máximo para uma resposta correta e justa.

Direitos: Os trabalhadores deverão ter o direito que a ouvidoria atue de imparcialmente frente a demanda, medie os conflitos e possa ter espaço para 
manifestar-se e argumentar de forma calma e clara, sobre a questão, e assim, colaborar com o ouvidor na melhor resolutividade da demanda.

O Ouvidor deverá reconhecer os direitos e deveres, tanto dos cidadãos como dos trabalhadores da saúde, para que sua ação não se torne focada e autoritária, não desencadeando mudanças eficientes, comprometendo, assim, seu trabalho.

\section{Ouvidor Não é Gestor}

A Ouvidoria SUS, conforme Glossário, elaborado pelo Ministério da Saúde é:
"Ouvidoria SUS, fem. Canal de comunicação entre a população e o SUS, para acolhimento de manifestações e busca de soluções e informações sobre serviços de saúde pública. Notas (1) a ouvidoria SUS é um serviço de mediação entre a demandante $e$ as áreas competentes pela resolutividade da demanda e, (ii) constitui-se em um instrumento de participação social e de apoio à gestão democrática para melhorias do SUS."
O Glossário elabora, quanto Ouvidor:

\footnotetext{
"Agente proativo de mudança, que media os interesses das diretrizes SUS e, que busca a melhoria da qualidade dos serviços de saúde".
}

Os conceitos acima, nos remetem ao papel fundamental do ouvidor, ou seja, de mediar em busca de melhoria dos serviços de saúde. O ouvidor não deverá ter a ação de solucionar problemas. Seu papel básico, conforme explicitado acima é mediar com imparcialidade e neutralidade as demandas levantadas.

\section{Procedimentos do Ouvidor}

\section{Mapear as Ouvidorias Existentes na Secretaria de Saúde}

O Ouvidor deverá conhecer, equipamentos de saúde do seu Estado Município, sua localidade e funções.

Considera-se que não é importante designar ouvidores para todos os equipamentos de saúde. No caso de município muito grande sugere-se que institua-se ouvidores de forma regionalizada.

Neste sentido as seguintes informações deverão ser mapeadas e disponibilizadas: 
- O Ouvidor

- Local

- Horário de Funcionamento

- Formas de contato

Faz-se bastante importante discutir ações da ouvidoria, buscando unificar o papel dos diversos ouvidores, envolver a rede de saúde nesta discussão e ampliando parcerias, procurando não criar distorções e mal entendidos com relação à sua atuação.

Com relação aos municípios de pequeno porte sugere-se que exista na medida do possível, ouvidorias regionais, uma vez, que existem parcerias para utilização dos equipamentos de saúde.

\section{Reuniões com o Gestor Central e Local}

Enfatiza-se que o apoio do gestor central e local, muito contribuirá para a efetivação da ouvidoria dentro da instituição pública de saúde.

A troca de informações com os gestores, faz com que a ouvidoria se torne um importante instrumento de gestão e participação social. Levantamento de indicadores, estatísticas por demandas, propor ações e publicizar a ouvidoria, demonstra que este canal é de grande importância.

Recomenda-se que haja reuniões quinzenais e/ou mensais com 0 gestor central, na impossibilidade com os assessores, para repassar o andamento e levantamento das demandas, demonstrar o andamento e sugerir propostas e discussões.

\section{Participação em Eventos na Área e Troca com Outros Ouvidores}

A participação do ouvidor em eventos da área visa aprimorar e trocar experiências, bem como, fomentar discussões, focadas para a área da saúde, buscando construir uma ouvidoria mais eficaz e competente.

Esta troca de informações entre os ouvidores da área da saúde, ou de outras áreas, contribuirá com o fortalecimento de suas ações, criando maiores subsídios para reforçar o papel da ouvidoria na instituição.

\section{Perfil do Ouvidor}


Algumas são as características básicas importante para constituir o perfil de um Ouvidor.

\section{Imparcialidade e Neutralidade}

O ouvidor da saúde deverá ser imparcial e neutro na sua atuação, frente ás demandas levantadas, agindo sempre com muita ponderação e justiça com relação às demandas acatadas pela ouvidoria.

\section{Proatividade}

Muitas vezes, confunde-se a proatividade do ouvidor com ações voltadas à resolutividade de problemas, ou seja, procurar problemas, resolver os problemas, conseguir vagas, marcar consultas, etc. O Ouvidor proativo é o que dissemina sua ação, discute com a rede de saúde, identifica pontos de estrangulamento mediante as demandas apresentadas, discute com o gestor central e local, faz reuniões, organiza estatísticas e levanta indicadores, sugere alternativas e propõe mudanças.

O perfil do ouvidor contempla ainda:

- Autonomia;

- Proceder eticamente;

- Buscar credibilidade e confiabilidade;

- Transparência;

- Sigilo profissional;

- Imparcialidade;

- Adotar postura pedagógica e propositiva do que constestatória, apresentando ao cidadão os seus direitos e deveres;

- Ter poder de negociação, para administrar conflitos;

- Ter responsabilidade, tanto interna quanto externa;

- Ter boa comunicação e relacionamento interpessoal; e

- Bom senso.

\section{INFRA-ESTRUTURA}


Toda ouvidoria deverá possuir uma estrutura básica. Abaixo algumas sugestões:

A Ouvidoria deverá ser minimamente composta por:

- 1 Ouvidor

- 1 Assistente do Ouvidor

- 1 Apoio Administrativo

- Pessoal:

- Treinado para atendimento ao público e que possa ser o apoio do ouvidor;

- Informatização:

- Criação de um software voltado, exclusivamente, para a ouvidoria:

- Forneça dados sobre forma de acesso;

- Demandas;

- Tratamento da demanda;

- Resolutividade,

- Tempo de resolutividade,

- Origem da reclamação; entre outras informações pertinentes.

- Homepage:

Seja construída uma Homepage na qual seja contemplado, na medida do possível:

- Guia geral - esclarecendo:

- O que se trata uma ouvidoria;

- Missão da ouvidoria;

- Objetivos da ouvidoria

- "antes de reclamar", informações sobre como proceder com uma reclamação.

É importante neste momento evidenciar que a ouvidoria é um canal para recebimento de primeira reclamação, sendo necessário, ao usuário/cidadão, fazer, na medida do possível, um esforço em resolver sua demanda, juntamente com a instituição; 
- Como reclamar? - ou seja como proceder com a reclamação;

- A quem se destina ouvidoria: qual o público alvo; quem poderá acessar a ouvidoria;

- Acesso: Formas de acesso da ouvidoria:

- e-mail,

- Telefones: telefone e linha gratuita, o que facilita o acesso, estimulando o usuário/cidadãono seu acesso a ouvidoria;

- Endereço: caso o usuário/cidadão queira registrar sua demanda presencialmente.

- Registro e número da demanda;

- Prazo para retorno da demanda - seja este retorno, positivo e/ou negativo;

- Formas de acompanhamento da demanda

- Identificação: Nome do ouvidor, formação profissional, tempo que deverá estar desenvolvendo esta função.

\section{- Formulário}

Com relação à formação profissional do ouvidor, sugere-se que seja da área de humanas, preferencialmente, com experiência com contato com o público.

Considera-se, que o ouvidor deverá ter um tempo mínimo de 1 a 2 anos na ouvidoria, para que ele possa, neste tempo, minimamente estruturar este canal de acesso ao cidadão.

- Relatórios: mensais, trimestrais ou semestrais, para que a população se intere e entenda a que se destina o seu acesso á ouvidoria, tornando-se, assim, mais confiante, com relação a este novo canal de comunicação, demonstrando, assim, transparência na ação da ouvidoria;

- Breve relato: breve relato mensal sobre assunto relevante que tenha sido solucionado e tenha trazido alguma mudança com relação a alguma prática, ou mesmo, alguma informação de interesse público. 
Considera-se importante que os relatos sejam os mais idôneos possíveis e que este canal, não venha a ser utilizado como propaganda política da gestão atual.

Ainda com relação à estrutura física da Ouvidoria:

- Sala privativa: na qual o ouvidor e/ou assessores, possam recepcionar os usuários que vêm pessoalmente a ouvidoria.

- Estrutura Básica da Sala Privativa para Atendimento:

- 1 sala

- 3 cadeiras

- 1 mesa

- Material de escritório: formulários específicos da ouvidoria, computador, impressora;

- 1 armário

- 1 arquivo

\section{FLUXO DA OUVIDORIA}

Instituir um fluxo de atendimento faz com que a ouvidoria, trabalhe de forma mais organizada, otimizando assim sua ação.

Para tanto, sugere-se que o Ouvidor estipule:

- Formas de acesso: carta, e-,mail, telefone, pessoalmente, através de terceiros? (irá aceitar este tipo de demanda?)

- Registro da demanda - geração de um número de processo, para que o usuário e, também o reclamado possa acessar para saber o andamento;

- Tratamento das demandas: urgentes, média urgência e, sem urgência;

- Inserir no computador a demanda, por problemática levantada: queixa de funcionários, mau atendimento, descaso, falta de informação e esclarecimentos; dificuldade de acesso; falta de profissionais especialistas ou não, demora, etc.

- Contatos com os reclamados: via e-mail, carta, ofício, memorando, telefone, fax, outras formas?

- Estipulação do tempo de resposta; 
- Recebida a resposta, analisar as duas partes e fazer sugestões ao gestor, do equipamento reclamado, e discutirem a melhor alternativa, focando sempre a justiça nesta relação;

- Responder ao usuário via: fax, carta, e-mail, pessoalmente, por telefone;

- Anotar no processo as ações referentes àquela demanda e, sendo finalizada, arquivar;

- Em caso de elogios, enviar para o equipamento elogiado, e colocar em reunião com o gestor central e local. A rede pública de saúde é carente de reforço positivo.

Esta é uma sugestão mínima de ação, podendo ser alterada e/ou suplementada. 


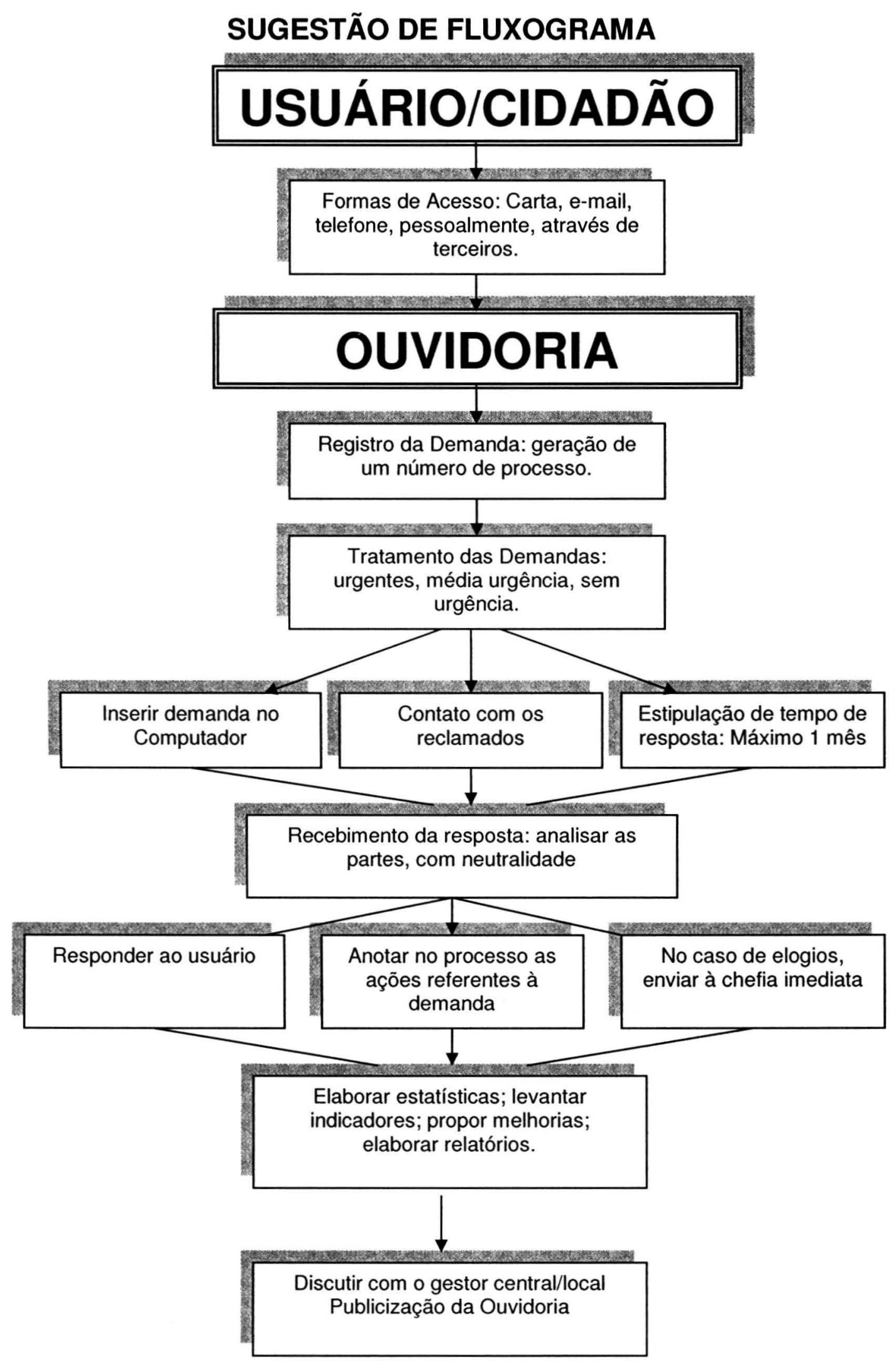




\section{Vantagens da Ouvidoria}

Com a contribuição de texto originado de discussão sobre o papel da ouvidoria na saúde, elaborado juntamente pela Professora Elza Ferreira Lobo, atual ouvidora da Secretaria do Estado da Saúde de São Paulo, Professor Paulo Fortes, Professor Associado da Faculdade de Saúde Pública da USP e por Simone Ribeiro Spinetti, aluna de pós-graduação, nível doutorado da Faculdade de Saúde Pública da USP. (s/d), juntamente com a colaboração do site do Governo da Paraíba, [http://www.saude.pb.gov.br/web_data/Ouvidoria/missão, acesso em 14 de maio de 2005], informamos à seguir:

\section{Das Vantagens da Ouvidoria para a Administração Pública}

A função do ouvidor dentro da administração pública, em seus diversos âmbitos e esferas, se bem delineada e trabalhada, poderá trazer vantagens ao administrador, tais como:

- Relacionamento democrático com a sociedade;

- Melhor direcionamento das ações;

- Transparência na administração pública;

- Utilização das reclamações, queixas, reivindicações e elogios como uma possibilidade de mudança política, programática ou de cultura institucional;

- Efetivação dos direitos dos usuários de manifestarem suas reivindicações;

- Racionalização e contribuições com relação ao gerenciamento dos recursos públicos;

- Credibilidade e fortalecimento da instituição junto à população;

- Parcerias em busca da melhoria e eficiência dos serviços prestados;

\section{Vantagens para o Cidadão:}

- Direito ao exercício da cidadania;

- Relacionamento democrático com a administração pública; 
- Disposição de um canal para expressar a sua opinião quanto aos serviços prestados;

- Acesso gratuito;

- Facilidade no uso do serviço;

- Resposta formal da solicitação;

- Obtenção de informações sobre serviços prestados.

\section{Desvantagens da Ouvidoria Frente ao não Entendimento e Comprometimento por parte do Gestor}

A Ouvidoria na saúde já é uma realidade, para tanto, necessita de apoio comprometimento e parceria por parte do gestor. Em não havendo este entendimento, o papel da ouvidoria poderá incorrer em alguns problemas tais como:

- Má utilização deste canal, possivelmente, caindo na falta de credibilidade do usuário;

- Utilização do canal da ouvidoria enquanto clientelismo;

- Multiplicação deste possível clientelismo, fazendo que com desencadeie pressões aos trabalhadores da saúde;

- Utilização da ouvidoria enquanto resolução de problemas pontuais, não trazendo nenhum benefício com relação à administração pública;

- Ações intransigentes e autoritárias do ouvidor, trazendo desconfianças e conflitos na sua relação com os trabalhadores da saúde;

Não cabe ao Ouvidor exercer papel punitivo ou de interferência na administração de uma instituição. Sua ação fundamenta-se na mediação entre o usuário do serviço de saúde e a instituição, podendo fazer recomendações, sugestões, reuniões, sempre buscando o diálogo e visando interesses comuns para uma gestão eficaz, para tanto, faz-se necessário o entendimento deste papel pelo gestor público, fazendo com que o mesmo se aproprie e contribua com a ouvidoria. 


\title{
ANEXO 2
}

\author{
ROTEIRO DE ENTREVISTA \\ OUVIDOR GERAL DO SUS \\ OUVIDOR DA SECRETARIA MUNICIPAL DE SAÚDE - A \\ OUVIDOR DA SECRETARIA MUNICIPAL DE SAÚDE - B
}

Instituição:

Quanto tempo de Prática como Ouvidor na área da saúde?

1) Comente sobre sua "história pessoal". Como chegou à função de ouvidor?

2) Comente sobre o "papel" do ouvidor nesta instituição de saúde.

3) Quais as ações desenvolvidas pelo Ouvidoria nesta instituição?

4) O que considera importante para que o papel do ouvidor da saúde se estabeleça? 


\title{
ANEXO 3
}

\section{TERMO DE CONSENTIMENTO LIVRE E ESCLARECIDO}

\author{
PAPEL TIMBRADO DA FACULDADE DE SAÚDE PÚBLICA
}

\section{TERMO DE CONSENTIMENTO LIVRE E ESCLARECIDO PARA OUVIDORES DA SAÚDE, NOS TRÊS NÍVEIS DE GOVERNO.}

Meu nome é Simone Ribeiro Spinetti. Sou aluna de doutorado da Faculdade de Saúde Pública - USP, estou realizando uma pesquisa intitulada "A Ouvidoria na Saúde: A Experiência da Cidade de São Paulo", que objetiva analisar a experiência da ouvidoria (SUS, Estadual e Municipais). Para tanto, gostaria de contar com sua participação, respondendo algumas questões, as quais serão gravadas. A entrevista será agendada conforme sua disponibilidade. A sua participação é livre e voluntária, podendo desistir em qualquer momento, sem que isto acarrete qualquer ônus pessoal ou profissional. As informações coletadas serão mantidas sob anonimato, a menos que o Sr.(a) consinta na exposição. O retorno da pesquisa será através da publicação de artigos científicos e participação em congressos, bem como discussões para disseminação do tema. Em havendo qualquer problema, ou caso queira alguma informação adicional, a pesquisadora poderá ser contatada no telefone e/ou endereço constantes deste Termo.

São Paulo, de de 200

Declaro que fui devidamente esclarecido(a) e consinto em participar da pesquisa

Cargo:

Simone Ribeiro Spinetti

Pesquisadora Responsável

Telefone para Contato: 


\section{ANEXO 4}

\section{LEVANTAMENTO DAS CATEGORIAS DE ANÁLISE}

\begin{tabular}{|c|c|}
\hline Categoria de Análise & Discurso do Ouvidor \\
\hline $\begin{array}{l}\text { Papel da Ouvidoria/Ouvidor } \\
\text { no Setor Público de Saúde }\end{array}$ & 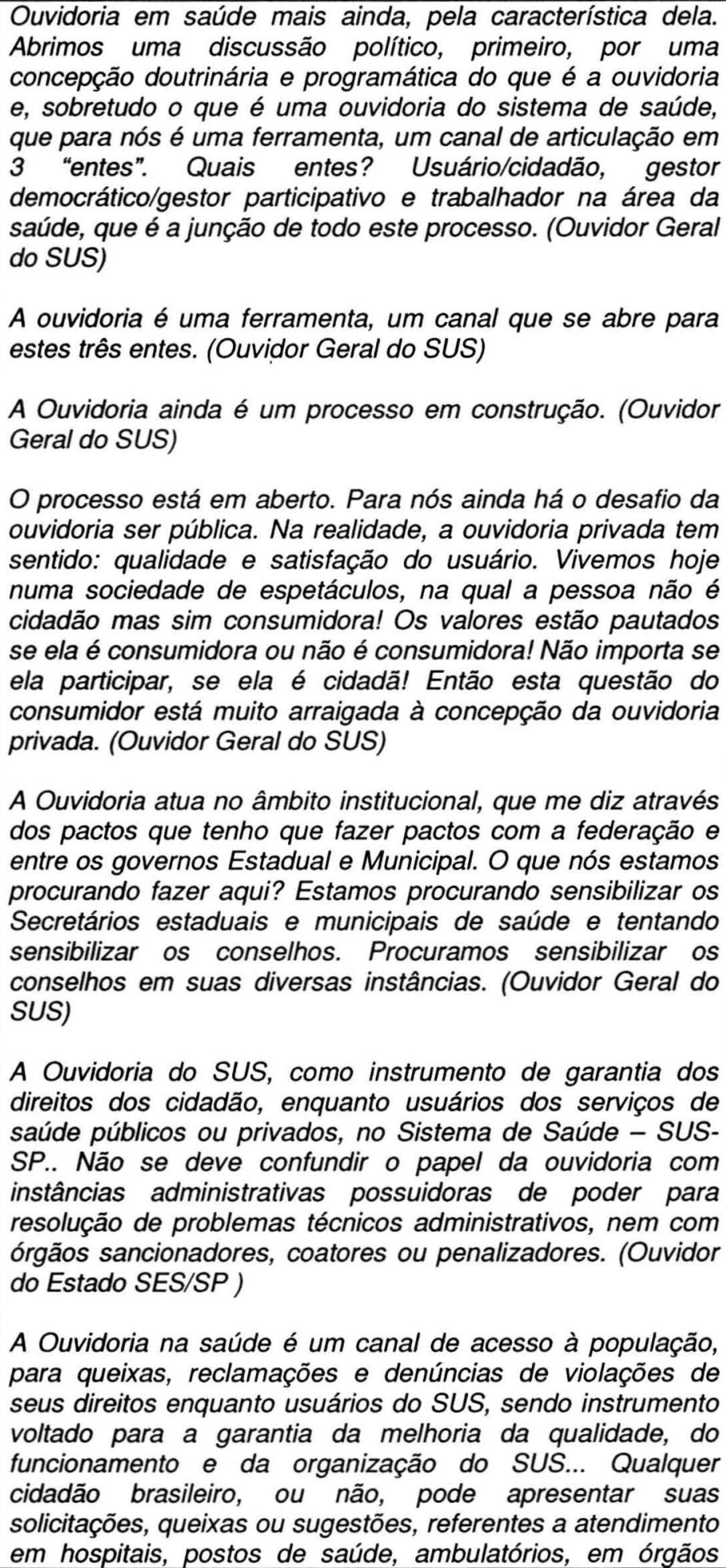 \\
\hline
\end{tabular}


públicos ou conveniados com o SUS. (Ouvidor do Estado SES/SP)

e eu continuo desde o início achando, o papel do ouvidor é de um técnico que conheça bem a estrutura de onde ele está localizado, e ele não tem que estar substituindo o papel do gestor local. Ele tem é que estar contribuindo, com os elementos para poder estar dizendo para o gestor... isto, isto, isto, o gestor é que vai dar a resposta. (Ouvidor do Estado SES/SP)

Interferir não é o papel da ouvidoria, como a gente fez todo o processo e como a gente foi construindo nesses anos todos. (Ouvidor do Estado SES/SP)

Em termos de informação, a ouvidoria tem o papel de receber as queixas, de receber informações, as demandas, mas, ela também tem o papel de informação. (Ouvidor do Estado SES/SP)

Nem sempre o usuário tem razão. Se, ele acha que tem, Você vai conversar com ele, vai mostrar, fazer entender qual é o caminho. Ele acha que tem que ser atendido, no dia que ele quer, e, não é por aí. Tem que entrar dentro do sistema. O Sistema tem um limite. (Ouvidor do Estado SES/SP)

Em alguns momentos tentaram, mas, assim, a ouvidoria, não é uma segunda porta para marcar consulta, resolver os problemas. Isto fica claro nas reuniões com os gestores. (Ouvidor do Estado SES/SP))

Em termos de informação, a ouvidoria tem o papel de receber as queixas, de receber informações, as demandas, mas, ela também tem o papel de informação. (Ouvidor do Estado SES/SP)

O papel do ouvidor nessa Secretaria, eu costumo dizer que é baseado em três perspectivas: a ouvidoria tem que ter a função de controle social, ela tem que fazer essa interlocução do usuário, ela tem que gerar indicadores para - gestor, qualificar a política de saúde que ele está utilizando. (Ouvidor $M-1$ )

Sempre que a gente sente que está com dificuldade, a gente faz uma solicitação, para poder fazer um contato com as Unidades e esclarecer e reiterar o que seria o objetivo da ouvidoria, por que ela é muito confundida com auditoria.(Ouvidor $M-1$ )

Quando a gente liga, as pessoas sabem que a gente ta ligando pra fazer uma queixa. Este ano, já fizemos duas reuniões com o departamento de políticas públicas de saúde com todos os gerentes das Unidades, pra poder retomar, qual a nossa proposta, que é de parceria, que é pra poder trabalhar um pouco mais este conceito novo, histórico e tentar fazer com que eles passem estas informações para os colegas que estão lá na ponta e que eles repassem para a equipe toda, porque não temos acesso à equipe toda. Essa é a entrada da rede, o acesso à rede. O Segundo ponto é gerar indicadores. (Ouvidor $M-1$ ) 
A gente tem vários indicadores: por especialidade, por região, qual a maior demanda, esse software nos dá esta possibilidade. Nós temos, assim, se a gente quiser fazer um levantamento da UBS $X$, qual a maior quantidade de queixas que a gente tem, a gente consegue ter dados muito significativos, que é pra gente responder e que a gente considera que é a nossa função. (M-1)

Então, nós pedimos uma reunião, quando o Departamento de Políticas de Saúde que faz a gestão de todas as unidades básicas, e, também as unidades de saúde mental, quando eles foram fazer uma reunião. Então, a idéia era discutir um pouco mais o conceito de ouvidoria, tirar as dúvidas que tivessem... então, essa reunião foi para sensibilizar os trabalhadores, para que eles pudessem sensibilizar suas equipes. (Ouvidor M-1)

È que realmente o serviço da ouvidoria conte com um serviço de atendimento ao usuário, que é realmente para ter essa entrada, de forma organizada e que isto gere indicadores e, que o ouvidor tenha este compromisso de gerar estes indicadores, colaborando com mudanças na política, ou edificar as políticas que estão sendo desenvolvidas por aí, se estamos seguindo o fluxo correto. Se alguém que está na função de ouvidoria, e não faz isto que é proposto acima, então ele não está na função de ouvidoria, ele deve ser um coordenador de SAC, mas a ouvidoria não dá pra não ser assim. (Ouvidor M-1)

Ouvir o paciente, comentar e já imediatamente encaminhar para a resolução. Acompanhar, mais assim, tudo dentro, de uma rapidez e de um dinamismo, para que o paciente seja atendido o mais rápido possível, para que ele tenha confiança e credibilidade com relação ao trabalho da ouvidoria. (Ouvidor M-2)

Ouvidoria é um canal livre para a população. Tanto para os funcionários e pacientes em geral. (Ouvidor M-2)

Os limites da ouvidoria, em termos de autonomia, a ouvidoria, ela tem uma autonomia, que não fica tão clara no papel, se ela tem esta autonomia. Já é um esteriótipo que a ouvidoria é uma autoridade. (Ouvidor M2)

Eu sinto uma dificuldade, e por isto que eu lamento que eu não tenha tempo suficiente, para fazer reuniões, para falar sobre o trabalho de uma ouvidoria, sobre o objetivo, sobre filosoficamente, qual é as funções verdadeiras de uma ouvidoria, que tem um papel importantíssimo, principalmente nos dias de hoje. (Ouvidor M-2)

Então, eu noto sim, mas ao mesmo tempo eu noto, eu observo que eles cumprem o papel. Provavelmente, não fazem assim entendendo, com profundidade, o que é o meu trabalho, a essência do meu trabalho, mas por conta, até deste, peso que tem a ouvidoria, este estigma, este temos inexplicável que eles têm, eles acabam fazendo um trabalho, onde o usuário é atendido conforme é seu direito. É assim, o usuário se queixa do tempo de espera de uma consulta. $O$ 
usuário está a 8 meses esperando uma consulta. Onde $o$ SUS está? (Ouvidor M-2)

Então, por isto, é que a minha avaliação, sem medo de errar, o usuário sempre tem razão! (Ouvidor M-2)

O usuário tem direitos e deveres... se é uma gestante que perdeu a consulta, ela tem que ser encaixada mesmo. Há casos e casos. O doente mental a gente concorda com tudo! Não tem o que fazer! Porque a pessoa não tem a mente sã. Não tem raciocínio lógico. Nós da saúde temos que vê-lo assim, ele é um doente. Tem que ter sentimentos, a sensibilidade o amor, o doente mental não tem nada disto. Ele tem este infortúnio na vida. Então, é assim que eu vejo. (Ouvidor M-2)

E, eu volto a insistir, que não é que eu saio só em defesa do usuário, mas eu fico com o meu norte: o cidadão tem direitos. (Ouvidor M-2)

Uma ouvidoria como eu, ele é amado e odiado. O ouvidor quando apareço, eu apareço, eu faço contatos. Apareço assim no meu trabalho. Eu não fico só no gabinete sentadinha... É uma necessidade intrínseca, e, é através dessa necessidade, que eu tenho uma forma, que vem, que fui no sentido de colaborar, ajudar, resolver, ser assim mediadora, para resolver aquele problema. (Ouvidor M-2)

Eu tenho um grande desafio a cada momento, que é solucionar problemas de pacientes que procuram a ouvidoria. (Ouvidor M-2)

Eu tenho o objetivo a médio e longo prazo de trabalhar a rede. Fazer visitas periódicas, reunir profissionais e passar realmente, fundamentando o papel da ouvidoria, a importância da ouvidoria, tirar este estigma do que é a ouvidoria é só pra denunciar, ir contra o profissional, então, sensibilizar, os servidores de uma forma geral, que nós todos servidores, temos uma missão: servir. Nós somos servidores e estamos sendo remunerados para servir a população. Eu tenho este desejo de falar muito sobre isto, porque, assim, existe uma cultura antiga: "olha, eu estou fazendo um favor", não é assim, isto é uma distorção. Nós estamos como servidores para servir a população. Neste contexto, atender, procurar facilitar, a vida daquele paciente dentre de uma unidade, evitando burocracia, ouvindo o que ele tem a dizer, esclarecendo, educando. (Ouvidor M-2)

É, que a ouvidoria é muito séria. Temos que passar para os funcionários o motivo e a responsabilidade de que é trabalhar em uma ouvidoria, ou seja, manter o sigilo, ter postura ética, atender com cortesia, fornecer informações precisas, ouvindo o cidadão, com respeito. (Ouvidor M-2)

As diretrizes do SUS. Então, eu me norteio por elas. (Ouvidor M-2)

Tudo passa pela minha mão. Eu tenha minha equipe, mas muitas vezes, isto é muito comum diariamente, as pessoas quererem falar comigo mesma. E eu estou aqui para isto. 


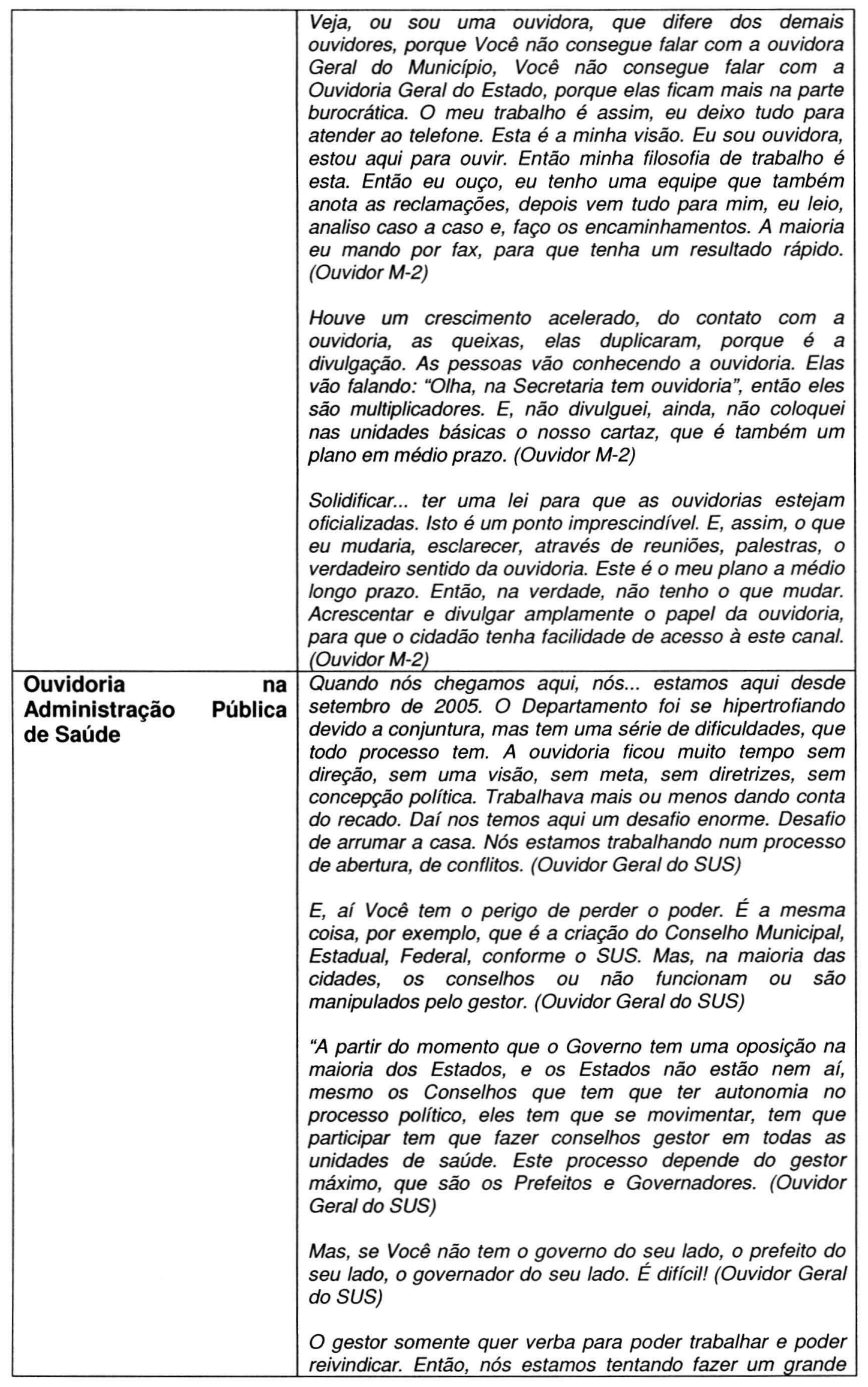


trabalho, que ainda está em aberto. Mas, como sensibilizar o gestor que não tem compromisso? (Ouvidor Geral do SUS)

Temos outra dificuldade muito grande que è saber onde se situa a ouvidoria. Se ela se situa no controle social ou na gestão. É uma discussão! Eu acho que a ouvidoria na saúde no SUS tem que estar localizada na gestão. Porque é a partir da gestão que Você pode sensibilizá-la. Se Você colocar no controle, Você perde o processo. O controle vai confundir a ouvidoria com o controle. Não vai participar, vai ficar só reivindicatório! Na gestão, vai depender do gestor. Se o gestor é um gestor democrático, ai há a possibilidade dela se capitalizar, transformando o controle social em participação social. O que eu quero é isto! (Ouvidor Geral do SUS)

O Humberto criou a ouvidoria, institucionalizou a mesma e integrou a ouvidoria dentro da Secretaria de Gestão Participativa, dentro de uma visão, de que a Gestão Participativa, englobaria todo este problema do controle social, de escuta, que no fundo, no fundo, não deixa de ter um certo fundamento. Dificulta para nós, enquanto ouvidoria, porque burocratiza um pouco o trabalho que poderia ser mais autônomo de nós estivéssemos ligados diretamente ao Ministério. A mesma coisa é o Departamento Nacional de Auditoria que é o DENASUS, que era ligado ao Ministro e que hoje está ligado também à Secretaria de Gestão Participativa. O que se pretendia com esta incorporação do DENASUS, era transformar a auditoria, não nesta visão fiscalizadora, mas sim numa visão de participação de pactuação, numa visão mais de solidariedade de ajuda. Não partir do princípio que todas as coisas erradas precisam ser punidas e que o gestor é isto, é aquilo, muitas vezes é falta até de ... da mesma forma nós estamos lá dentro. Se for correto estarmos juntamente com a Secretaria de Gestão Participativa, eu diria que tem esse viés que é político, ideológico, participativo, democrático. Agora, dentro do processo, digamos de autonomia, ela deveria estar ligada ao Ministério. (Ouvidor Geral do SUS)

Porque se ela estivesse ligada ao Ministro, Você teria uma articulação com todas as secretarias do Ministério. Seria muito mais fácil. E hoje nós temos uma dificuldade de fazer esta conexão, pois nós estamos dentro de uma secretaria. Para sensibilizar a secretaria já é difícil, porque a visão de ouvidoria é uma coisa em construção. Então nós não conseguimos sensibilizar a própria Secretaria de Gestão Participativa, e por via de conseqüência, nós temos dificuldades de sensibilizar o Ministério da Saúde como um todo. Dentro da visão do Ministério, a ouvidoria ficou numa visão fragmentada. Nós vamos alcançar nossa legitimidade no processo, quando formos reconhecidos. Quando o reconhecimento vem a legitimação vem em conseqüência. Nós temos é que mostrar serviço. (Ouvidor Geral do SUS)

A ouvidoria é uma ferramenta de gestão! Sim, ela é uma ferramenta de gestão, é também uma ferramenta de controle social. A ouvidoria é só uma ferramenta de controle social? Não, não é, então para mudar a história, ela é uma ferramenta de participação social, ou seja, de gestão 
participativa. Além de ser democrática. Entre gestão democrática e gestão participativa tem uma diferença muito grande. Quando eu boto um usuário, um cidadão, um povo para participar do processo. Outra questão é que a ouvidoria não é serviço social. Nós não estamos aqui para resolver problema dos outros. Estamos aqui para abrir um canal para eles entrarem no processo. (Ouvidor Geral do SUS)

Tem lugares onde a Ouvidoria dá certo e tem outros que não dá certo. Ela dá certo onde tem comprometimento do Gestor.(Ouvidor Geral do SUS)

O Decreto propõe que a ouvidoria seja um sistema, e este sistema funciona descentralizando o processo. Não é só descentralizar, é descentralizar com centralização. Quando Você descentraliza e perde o caráter normativo, o caráter político e o caráter formulador. Então, Você apenas descentraliza, libera a verba e deixa ir no fluxo de cada um. Aí não dá! De jeito nenhum! (Ouvidor Geral do SUS)

Não adianta, colocar um decreto ou uma lei e dizer, olha, a partir de hoje, Vocês vão fazer isto! Daí ele responde de lá: mas eu tenho condições de fazer isto? Então tem que ir na limitação que é. Tudo tem que ser conversado, discutido. (Ouvidor Geral do SUS)

Na Secretaria de Estado da Saúde, acredito que o papel do ouvidor da saúde já esteja bem difundido estabelecido nas diferentes instâncias de gestão do Sistema de Saúde, nos Hospitais, Institutos, Centros de Referência e Ambulatórios de Especialidades e Unidades Básicas de Saúde. Vimos, mantendo boa relação com as ouvidorias das FundaÇões, Autarquias e Universidade e no caso específico da Cidade, também com a Ouvidoria Geral do Município. Ao todo devemos ter no Sistema de Ouvidoria da Saúde, em torno de 150 pessoas desempenhando uma nova função de Ouvidoria. (Ouvidor do Estado SES/SP)

A ouvidoria está diretamente ligada ao Gabinete, então, os problemas que a gente tem e que não se consegue se organizar diretamente, ou que necessite de outro, são discutidos na Chefia de Gabinete. Os relatórios que são semestrais são relatórios que são repassados, pro Secretário, que é quem, que avalia, tudo que foi trazido, para encaminhar pro Governador. E, internamente, isto é discutido, na reunião de coordenadores. $E$, todos os diretores das Direções Regionais de Saúde, vêm na Ouvidoria um braço de apoio e de termômetro. Isto é o interessante. (Ouvidor do Estado SES/SP)

Você percebe que num dia, Você tem 3 a 4 demandas de uma mesma região. Você pode ter certeza que Você está tendo algum problema. E o que Você tem que fazer é entrar em contato com o gestor, para ele ver o que está ocorrendo. O nosso gestor com a intermediação com o ouvidor, poderá estar vendo o que está ocorrendo ali... (Ouvidor do Estado $S E S / S P$ )

A impressão que eu tenho, é que os que estão dentro das unidades, como já são vários anos de ouvidoria, eles acham 


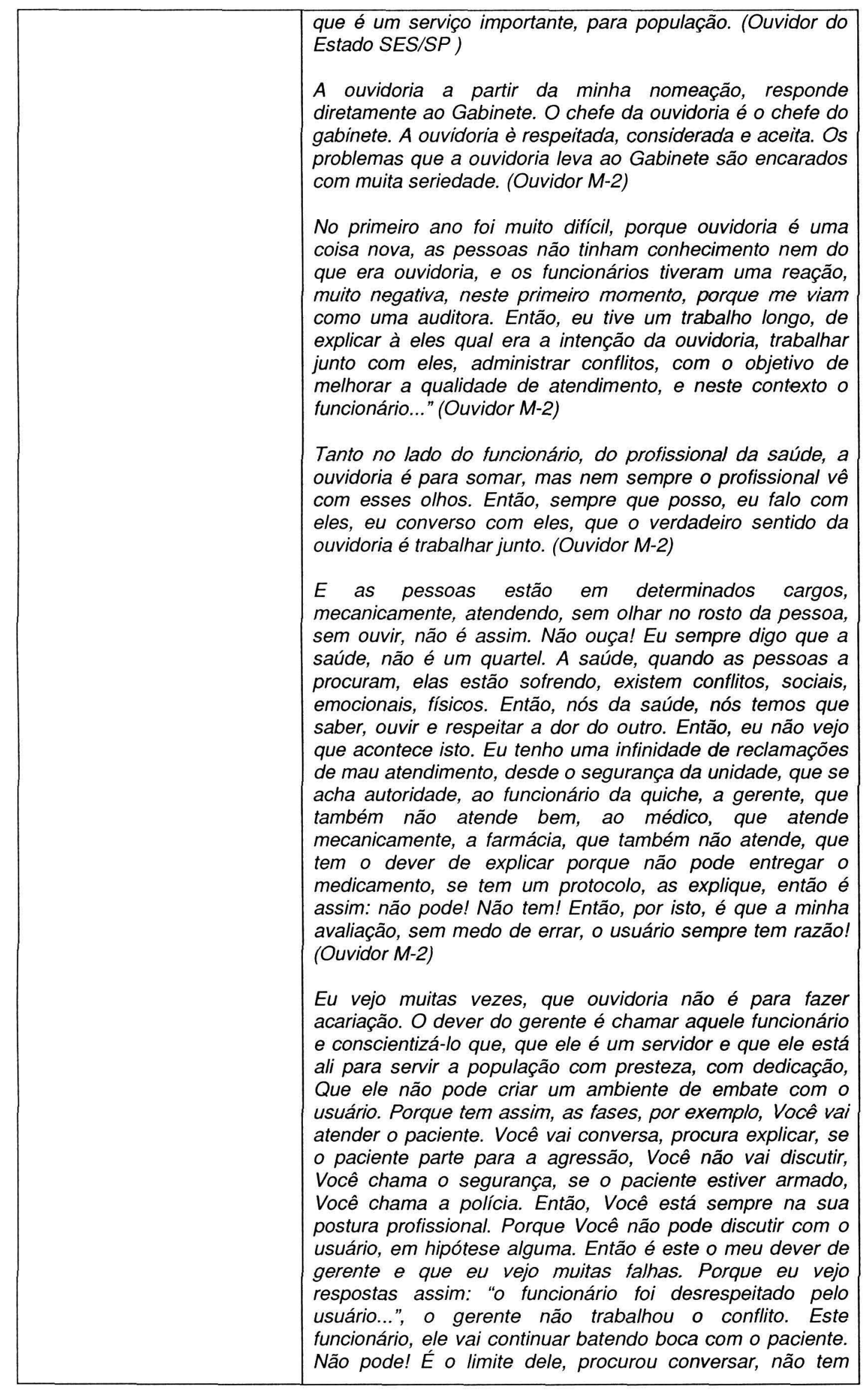




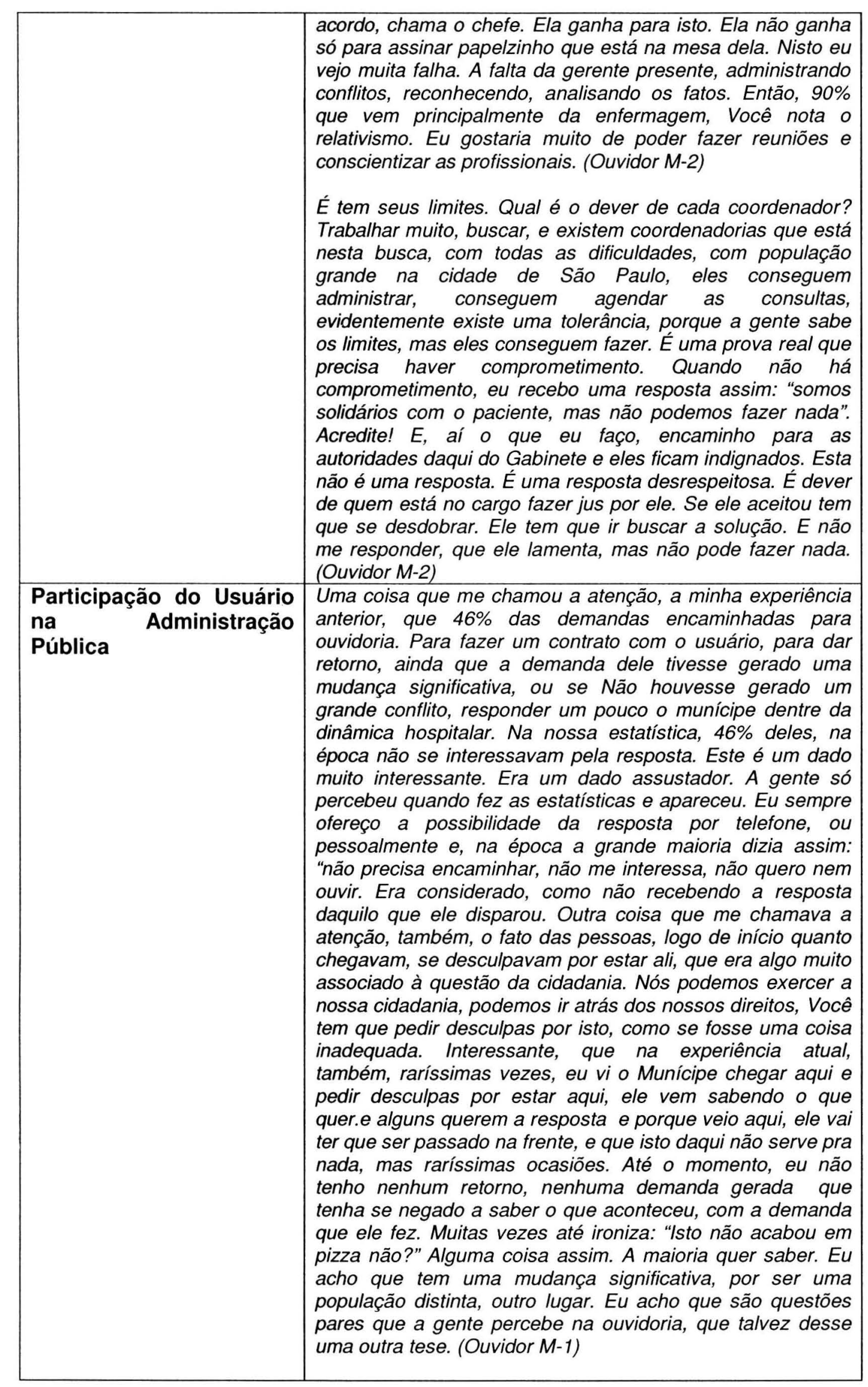




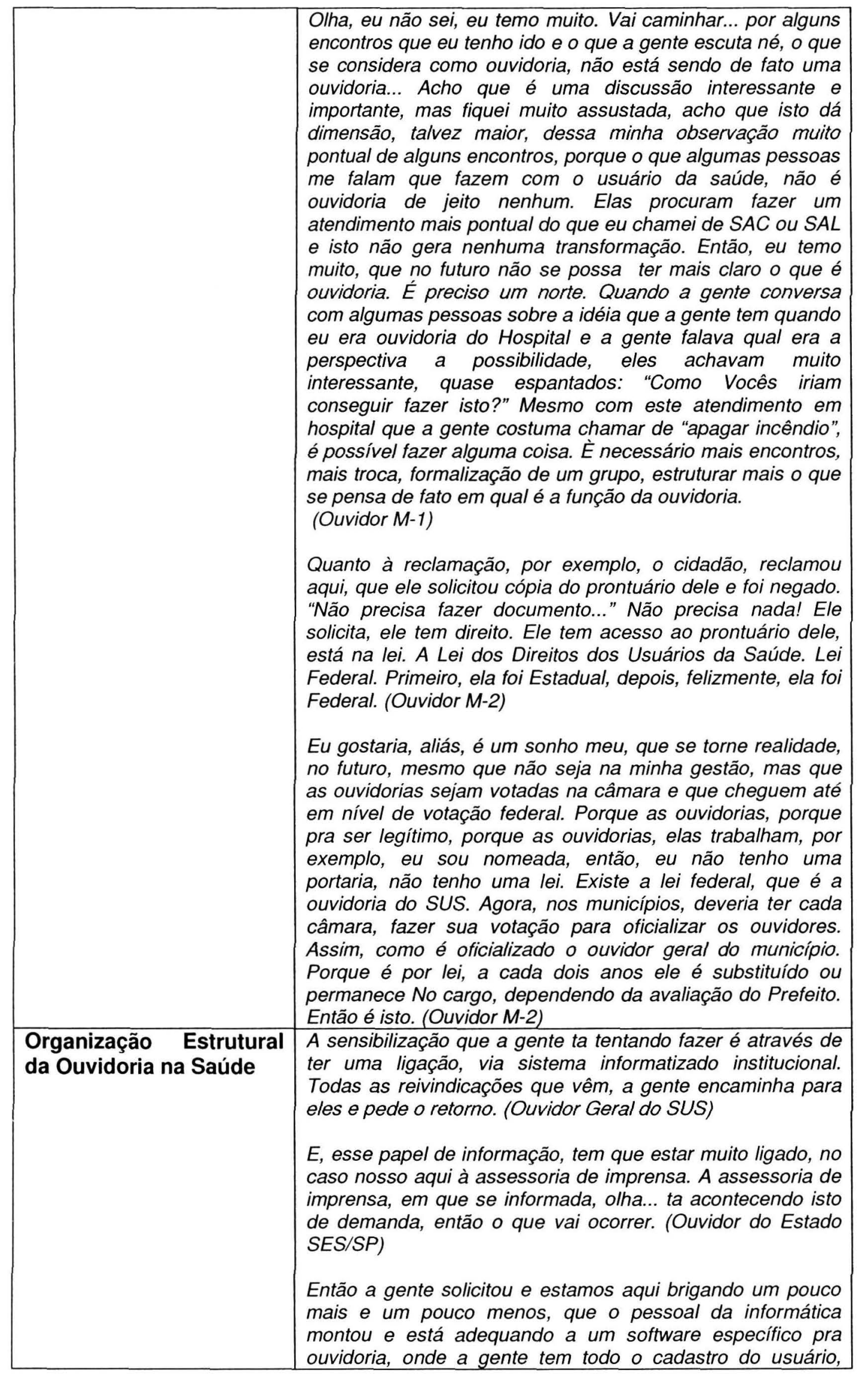




\begin{tabular}{|c|c|}
\hline & $\begin{array}{l}\text { cadastro do reclamante, e que este software gera um monte } \\
\text { de relatórios que podem te dar a classificação para o que a } \\
\text { pessoa veio. O problema de acesso, de aparelhos cirurgia, } \\
\text { APAC, SADT, unidades de assistência, tratamento fora do } \\
\text { domicílio. A gente tem dentro desse software, que se } \\
\text { chamava ouvido, foi batizado pelo rapaz que delineou. Ele } \\
\text { quis pensar um nome que tivesse um significado maior. } \\
\text { (Ouvidor } M-1 \text { ) } \\
\text { Nós temos um e-mail da ouvidoria. Não tem um software } \\
\text { para a ouvidoria. (Ouvidor } M-1 \text { ) }\end{array}$ \\
\hline Publicização & $\begin{array}{l}\text { Então, nos fizemos o nosso projeto para o planejamento de } \\
2006 \text { e dentro do planejamento a gente fez uma solicitação, } \\
\text { que além de gerar estes indicadores pro gestor, que eles } \\
\text { sejam publicados né, com uma certa periodicidade, porque a } \\
\text { gente acha que isto tem que ficar publicado. Mas, isto está } \\
\text { encaminhado e a gente vai ter que ver o que vai ser dessa } \\
\text { sugestão que a gente deu, se vai ser aprovada ou não. } \\
\text { (Ouvidor M-1) } \\
\text { Com relação à população, a gente entende que deveria ser } \\
\text { feita uma divulgação. Há coisa de } 4 \text { meses atrás, a emissora } \\
\text { de TV que é a Rede Globo local, ela fez uma matéria sobre } \\
\text { ouvidoria na saúde. Veio até aqui, entrevistou o Secretário } \\
\text { Adjunto, e fez uma matéria explicando como a ouvidoria } \\
\text { funcionava. Então, nessa ocasião teve uma divulgação. } \\
\text { (Ouvidor M-1) } \\
\text { A gente tem um projeto que também foi pro planejamento da } \\
\text { ouvidoria, que é para não ficar nessa posição passiva, que é } \\
\text { acolher somente o munícipe que vem aqui. São duas } \\
\text { perspectivas, uma é a gente colocar todos os locais, e isto } \\
\text { está dentro do decreto e todos os locais, sejam da rede } \\
\text { pública ou de prestadores de serviços também, uma espécie } \\
\text { de caixa de sugestão, que seria da ouvidoria, e, ali a gente } \\
\text { coletaria queixas, sugestões, etc. Esta também seria uma } \\
\text { forma passiva, mas teria a presença da ouvidoria, através da } \\
\text { caixa de sugestão em cada unidade. E, a outra intenção é } \\
\text { fazer pesquisa com o munícipe. Fazer uma pesquisa ativa } \\
\text { periódica. Fazer essa comparação de dados, mas, isto a } \\
\text { gente não realizou ainda. Ainda é um projeto. (Ouvidor M-1) }\end{array}$ \\
\hline
\end{tabular}

